Supporting Information for:

\title{
Targeted degradation of the oncogenic microRNA 17-92 cluster by structure-targeting ligands
}

Xiaohui Liư ${ }^{\dagger}$ Hafeez S. Haniff ${ }^{\dagger}$, Jessica Childs-Disney, Anton Shuster, Haruo Aikawa, Alexander Adibekian, and Matthew D. Disney*

The Scripps Research Institute, Department of Chemistry, 130 Scripps Way, Jupiter, FL 33458,

USA

tThese authors contributed equally to this work.

*author to whom correspondence should be addressed

Email: disney@scripps.edu

\section{Table of Contents}

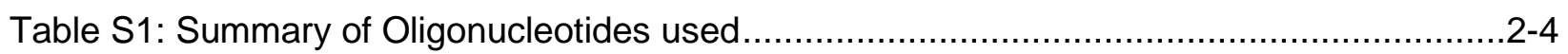

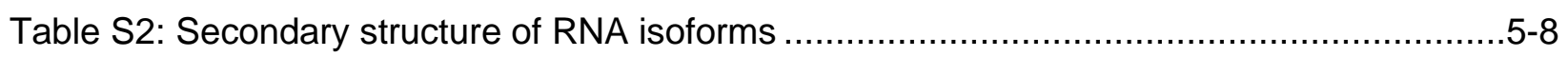

Figure S1: Luciferase screen of dimer library for de-repression of PPARa ................................

Figure S2: In vitro Dicer inhibition of pre-miR-17 and mutants with 2 ................................10

Figure S3: In vitro Dicer inhibition of pre-miR-18a, and pre-miR-20a with $2 \ldots \ldots \ldots \ldots \ldots \ldots \ldots \ldots . . .11$

Figure S4: In vitro Dicer inhibition of pre-miR-19a, -19b, and 92a-1 with $2 \ldots \ldots \ldots \ldots \ldots \ldots \ldots \ldots \ldots . . .12$

Figure S5: Confocal imaging of 2, 5, and 7 in DU145 cells...............................................

Figure S6: ZBTB4 mRNA and Invasion for 2 in MDA-MB-231 cells..................................14

Figure S7: Activity of 2 on the expression of miRs in miR-17-92 cluster in WT 9-12 cells..........15

Figure S8: STK4 mRNA and Caspase 3/7 controls for 2 in DU-145 cells ..............................16

Figure S9: In vitro Cleavage 5 and 6 on pre-miR-17, mutant pre-miR-17, and DNA .................17

Figure S10: RT-qPCR and phenotype for controls in MDA-MB-231 cells ..............................18

Figure S11: RT-qPCR and phenotype for controls in DU-145 cells ..............................19-20

Figure S12: Global protein expression changes in DU-145 cells treated with 5 .................21-22

Figure S13: Absolute quantification of RIBOTAC activity in MDA-MB-231 and DU145 cells .....23

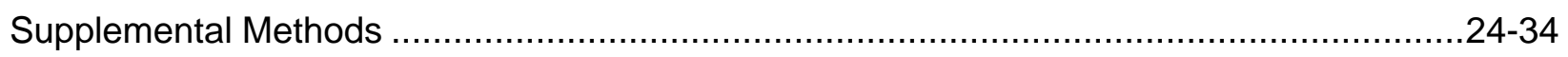

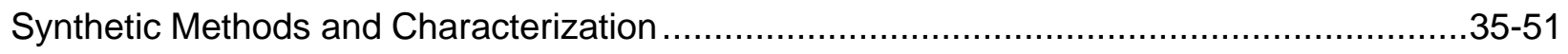

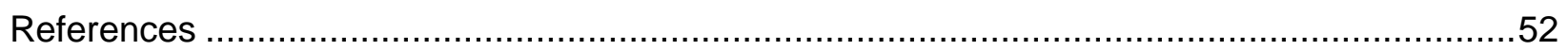




\begin{tabular}{|c|c|c|c|}
\hline Oligonucleotide & Sequence $5^{\prime}$-> 3' & Experiment & Supplier \\
\hline hsa-miR-17 & CAAAGTGCTTACAGTGCAGGTAC & RT-qPCR & Europhins \\
\hline has-miR-18a & TAAGGTGCATCTAGTGCAGATAG & RT-qPCR & Europhins \\
\hline has-miR-19a & TGTGCAAATCTATGCAAAACTGA & RT-qPCR & Europhins \\
\hline has-miR-20a & TAAAGTGCTTATAGTGCAGGTAG & RT-qPCR & Europhins \\
\hline has-miR-19b & TGTGCAAATCCATGCAAAACTGA & RT-qPCR & Europhins \\
\hline has-miR-92a-1 & TATTGCACTTGTCCCGGCCTGT & RT-qPCR & Europhins \\
\hline RNU6 & ACACGCAAATTCGTGAAGCGTTC & RT-qPCR & IDT \\
\hline $\begin{array}{l}\text { Universal } \\
\text { Reverse }\end{array}$ & GAATCGAGCACCAGTTACGC & RT-qPCR & IDT \\
\hline $\begin{array}{l}\text { Pri-miR-17/92 5' } \\
\text { Fwd. }\end{array}$ & GGAATTAATTGCTGTTAGGAGGTTGGA & RT-qPCR & IDT \\
\hline $\begin{array}{c}\text { Pri-miR-17/92 5' } \\
\text { Rev }\end{array}$ & AGGTCCACGTGTATGACTGG & RT-qPCR & IDT \\
\hline $\begin{array}{l}\text { Pri-miR-17/92 3' } \\
\text { Fwd. }\end{array}$ & TTATGTTCCCTACTCCCTACGTAAGC & RT-qPCR & IDT \\
\hline $\begin{array}{c}\text { Pri-miR-17/92 3' } \\
\text { Rev }\end{array}$ & AGAAAAGAGAGAAGGCAGAAATGCTG & RT-qPCR & IDT \\
\hline STK4 Fwd. & GATGGGCACTGTCCGAGTAG & RT-qPCR & IDT \\
\hline STK4 Rev & GCAACGTGTCATCGTGCTC & RT-qPCR & IDT \\
\hline ZBTB4 Fwd. & GGCACGAACTGACAAGACTTGA & RT-qPCR & IDT \\
\hline ZBTB4 Rev & TGTGGCGACGTGATTAA & RT-qPCR & IDT \\
\hline 18S Fwd. & GTAACCCGTTGAACCCCATT & RT-qPCR & IDT \\
\hline 18S Rev & CCATCCAATCGGTAGTAGCG & RT-qPCR & IDT \\
\hline GAPDH Fwd. & GTTCGACAGTCAGCCGCATC & RT-qPCR & IDT \\
\hline GAPDH Rev & GGAATTTGCCATGGGTGGA & RT-qPCR & IDT \\
\hline $\begin{array}{l}\text { miR-17 Dicer } \\
\text { Site Mimic }\end{array}$ & $\begin{array}{l}\text { GUGCAGGUAGUGAUAUGUGCAUCUAC } \\
\text { UGCAC }\end{array}$ & $\begin{array}{l}\text { Binding } \\
\text { Assay }\end{array}$ & Dharmacon \\
\hline $\begin{array}{l}\text { miR-17 Dicer } \\
\text { Site Mimic } \\
\text { Mutant Fwd. }\end{array}$ & TAATACGACTCACTATAGG & $\begin{array}{l}\text { Binding } \\
\text { Assay }\end{array}$ & IDT \\
\hline $\begin{array}{c}\text { miR-17 Dicer } \\
\text { Site G Bulge T7 } \\
\text { template }\end{array}$ & $\begin{array}{c}\text { TAATACGACTCACTATAGGGTGCAGGT } \\
\text { AGATGATATGTGCATCTACTGCAC }\end{array}$ & $\begin{array}{l}\text { Binding } \\
\text { Assay }\end{array}$ & IDT \\
\hline $\begin{array}{c}\text { miR-17 Dicer } \\
\text { Site G Bulge } \\
\text { Rev }\end{array}$ & GTGCAGTAGATGCACATA & $\begin{array}{l}\text { Binding } \\
\text { Assay }\end{array}$ & IDT \\
\hline $\begin{array}{c}\text { miR-17 Dicer } \\
\text { Site U Bulge } \\
\text { Mimic }\end{array}$ & $\begin{array}{c}\text { TAATACGACTCACTATAGGGTGCAGGT } \\
\text { AGTGATATGTGCATCTACCTGCAC }\end{array}$ & $\begin{array}{l}\text { Binding } \\
\text { Assay }\end{array}$ & IDT \\
\hline $\begin{array}{c}\text { miR-17 Dicer } \\
\text { Site G Bulge } \\
\text { Rev }\end{array}$ & GTGCAGGTAGATGCACAT & $\begin{array}{l}\text { Binding } \\
\text { Assay }\end{array}$ & IDT \\
\hline $\begin{array}{l}\text { miR-17 Base } \\
\text { Pair Control }\end{array}$ & $\begin{array}{c}\text { GUGCAGGUAGAUGAUAUGUGCAUCUA } \\
\text { CCUGCAC }\end{array}$ & $\begin{array}{l}\text { Binding } \\
\text { Assay }\end{array}$ & Dharmacon \\
\hline $\begin{array}{l}\text { Pre-miR-17 T7 } \\
\text { Fwd. }\end{array}$ & $\begin{array}{c}\text { GGCCGGATCCTAATACGACTCACT } \\
\text { ATAGGTCAAAGTGCTTACAGTGCAGG }\end{array}$ & $\begin{array}{l}\text { Dicer } \\
\text { Inhibition }\end{array}$ & IDT \\
\hline
\end{tabular}




\begin{tabular}{|c|c|c|c|}
\hline Pre-miR-17 Rev & GCTACAAGTGCCTTCACTG & $\begin{array}{c}\text { Dicer } \\
\text { Inhibition }\end{array}$ & IDT \\
\hline $\begin{array}{l}\text { Pre-miR-17 } \\
\text { Template }\end{array}$ & $\begin{array}{c}\text { TCAAAGTGCTTACAGTGCAGGTAGTGA } \\
\text { TATGTGCATCTACTGCAGTGA AGG } \\
\text { CAC TTG TAGC }\end{array}$ & $\begin{array}{l}\text { Dicer } \\
\text { Inhibition }\end{array}$ & IDT \\
\hline $\begin{array}{l}\text { Pre-miR-17-G21 } \\
\text { Mutant Template }\end{array}$ & $\begin{array}{c}\text { TCAAAGTGCTTACAGTGCAGGTAG } \\
\text { TGATATGTGCATCTACCTGCAGTGA } \\
\text { AGGCACTTGTAGC }\end{array}$ & $\begin{array}{l}\text { Dicer } \\
\text { Inhibition }\end{array}$ & IDT \\
\hline $\begin{array}{l}\text { Pre-miR-17-U37 } \\
\text { Mutant Template }\end{array}$ & $\begin{array}{c}\text { TCAAAGTGCTTACAGTGCAGGTAGA } \\
\text { TGATATGTGCATCTACTGCAGTGAAGG } \\
\text { CACTTGTAGC }\end{array}$ & $\begin{array}{l}\text { Dicer } \\
\text { Inhibition }\end{array}$ & IDT \\
\hline $\begin{array}{l}\text { Pre-miR17- } \\
\text { G21/U37 Mutant } \\
\text { Template }\end{array}$ & $\begin{array}{c}\text { TCAAAGTGCTTACAGTGCAGGTAG } \\
\text { ATGATATGTGCATCTACCTGCAGT } \\
\text { GAAGGCACTTG }\end{array}$ & $\begin{array}{l}\text { Dicer } \\
\text { Inhibition }\end{array}$ & IDT \\
\hline $\begin{array}{l}\text { Pre-miR-18a T7 } \\
\text { Fwd }\end{array}$ & $\begin{array}{c}\text { GGCCGCATGGTAATACGACTCACTATA } \\
\text { GGTAAGGTGCAT CTAGTGCAG }\end{array}$ & $\begin{array}{l}\text { Dicer } \\
\text { Inhibition }\end{array}$ & IDT \\
\hline $\begin{array}{l}\text { Pre-miR-18a } \\
\text { Rev }\end{array}$ & CCAGAAGGAGCACTTAGG & $\begin{array}{c}\text { Dicer } \\
\text { Inhibition }\end{array}$ & IDT \\
\hline $\begin{array}{l}\text { Pre-miR-18a } \\
\text { Template }\end{array}$ & $\begin{array}{c}\text { TAAGGTGCATCTAGTGCAGATAGTGAA } \\
\text { GTAGATTAG } \\
\text { CATCTACTGCCCTAAGTGCTCCTTCTG } \\
\text { G }\end{array}$ & $\begin{array}{l}\text { Dicer } \\
\text { Inhibition }\end{array}$ & IDT \\
\hline $\begin{array}{l}\text { Pre-miR-18a- } \\
\text { U37 Template }\end{array}$ & $\begin{array}{c}\text { TAAGGTGCATCTAGTGCAGATAGATGA } \\
\text { AGTAGATTAG } \\
\text { CATCTACTGCCCTAAGTGCTCCTTCTG } \\
\text { G }\end{array}$ & $\begin{array}{l}\text { Dicer } \\
\text { Inhibition }\end{array}$ & IDT \\
\hline $\begin{array}{l}\text { Pre-miR-20a T7 } \\
\text { Fwd }\end{array}$ & $\begin{array}{c}\text { GGCCGGATCCTAATACGACTCACTATA } \\
\text { GGGACTAAAGTGCTTATAGTGCAGG }\end{array}$ & $\begin{array}{c}\text { Dicer } \\
\text { Inhibition }\end{array}$ & IDT \\
\hline $\begin{array}{c}\text { Pre-miR-20a } \\
\text { Rev }\end{array}$ & ACTTTAAGTGCTCATAATGCAG & $\begin{array}{c}\text { Dicer } \\
\text { Inhibition }\end{array}$ & IDT \\
\hline $\begin{array}{l}\text { Pre-miR-20a } \\
\text { Template }\end{array}$ & $\begin{array}{c}\text { ACTAAAGTGCTTATAGTGCAGGTAGTG } \\
\text { TTTAGTTATCTACTGCATTATGAGCACT } \\
\text { TAAAGT }\end{array}$ & $\begin{array}{l}\text { Dicer } \\
\text { Inhibition }\end{array}$ & IDT \\
\hline $\begin{array}{l}\text { Pre-miR-19a T7 } \\
\text { Fwd }\end{array}$ & $\begin{array}{c}\text { GGCCGGATCCTAATACGACTCACTATA } \\
\text { GGGTTAGTTTTGCATAGTTGCACT }\end{array}$ & $\begin{array}{c}\text { Dicer } \\
\text { Inhibition }\end{array}$ & IDT \\
\hline $\begin{array}{c}\text { Pre-miR-19a } \\
\text { Rev }\end{array}$ & TCAGTTTTGCATAGATTTGCA & $\begin{array}{c}\text { Dicer } \\
\text { Inhibition }\end{array}$ & IDT \\
\hline $\begin{array}{l}\text { Pre-miR-19a } \\
\text { Template }\end{array}$ & $\begin{array}{c}\text { TTAGTTTTGCATAGTTGCACTACAAGAA } \\
\text { GAATGTAGTTGTGCAAATCTATGCAAAA } \\
\text { CTGA }\end{array}$ & $\begin{array}{l}\text { Dicer } \\
\text { Inhibition }\end{array}$ & IDT \\
\hline $\begin{array}{l}\text { Pre-miR-19b T7 } \\
\text { Fwd }\end{array}$ & $\begin{array}{c}\text { GGCCGGATCCTAATACGACTCACTATA } \\
\text { GGGTTAGTTTTGCAGGTTTGCA }\end{array}$ & $\begin{array}{c}\text { Dicer } \\
\text { Inhibition }\end{array}$ & IDT \\
\hline $\begin{array}{c}\text { Pre-miR-19b } \\
\text { Rev }\end{array}$ & AGTCAGTTTTGCATGGATTTG & $\begin{array}{c}\text { Dicer } \\
\text { Inhibition }\end{array}$ & IDT \\
\hline $\begin{array}{l}\text { Pre-miR-19b } \\
\text { Template }\end{array}$ & $\begin{array}{c}\text { GGTTAGTTTTGCAGGTTTGCATCCAGC } \\
\text { TGTGTGATATTC } \\
\text { TGCTGTGCAAATCCATGCAAAACTGAC } \\
\frac{T}{}\end{array}$ & $\begin{array}{l}\text { Dicer } \\
\text { Inhibition }\end{array}$ & IDT \\
\hline $\begin{array}{l}\text { Pre-miR-92a-1 } \\
\text { Fwd. }\end{array}$ & $\begin{array}{c}\text { GGCCGGATCCTAATACGACTCACTATA } \\
\text { GGGCACAGGTTGGGATCGGTT }\end{array}$ & $\begin{array}{l}\text { Dicer } \\
\text { Inhibition }\end{array}$ & IDT \\
\hline
\end{tabular}




\begin{tabular}{|c|c|c|c|}
\hline $\begin{array}{l}\text { Pre-miR-92a-1 } \\
\text { Rev }\end{array}$ & AACAGGCCGGGACAAGT & $\begin{array}{c}\text { Dicer } \\
\text { Inhibition }\end{array}$ & IDT \\
\hline $\begin{array}{l}\text { Pre-miR-92a-1 } \\
\text { Template }\end{array}$ & $\begin{array}{c}\text { CACAGGTTGGGATCGGTTGCAATGCTG } \\
\text { TGTTTCTGTATGGTATTGCACTTGTCCC } \\
\text { GGCCTGTT }\end{array}$ & $\begin{array}{l}\text { Dicer } \\
\text { Inhibition }\end{array}$ & IDT \\
\hline PD-L1 Forward & TGGACAAGCAGTGACCATCAA & RT-qPCR & IDT \\
\hline PD-L1 Reverse & GGATGTGCCAGAGGTAGTTC & RT-qPCR & IDT \\
\hline $\begin{array}{l}\text { Pre-miR-18a } \\
\text { Fwd. }\end{array}$ & TAAGGTGCATCTAGTGCAGATAG & RT-qPCR & IDT \\
\hline $\begin{array}{l}\text { Pre-miR-18a } \\
\text { Rev }\end{array}$ & GAAGGAGCACTTAGGGCAGT & RT-qPCR & IDT \\
\hline $\begin{array}{l}\text { T7-miR-17 } \\
\text { template }\end{array}$ & $\begin{array}{c}\text { TAATACGACTCACTATAGGCAAAGTGC } \\
\text { TTACAGTGCAGGTAG }\end{array}$ & Transcription & IDT \\
\hline $\begin{array}{l}\text { T7-miR-18a } \\
\text { template }\end{array}$ & $\begin{array}{c}\text { TAATACGACTCACTATAGGTAAGGTGC } \\
\text { ATCTAGTGCAGATAG }\end{array}$ & Transcription & IDT \\
\hline $\begin{array}{l}\text { T7-miR-20a } \\
\text { template }\end{array}$ & $\begin{array}{l}\text { TAATACGACTCACTATAGGTAAAGTGCT } \\
\text { TATAGTGCAGGTAG }\end{array}$ & Transcription & IDT \\
\hline $\begin{array}{l}\text { T7-miR-19a } \\
\text { template }\end{array}$ & $\begin{array}{l}\text { TAATACGACTCACTATAGGTGTGCAAAT } \\
\text { CTATGCAAAACTGA }\end{array}$ & Transcription & IDT \\
\hline $\begin{array}{l}\text { T7-miR-19b-1 } \\
\text { template }\end{array}$ & $\begin{array}{l}\text { TAATACGACTCACTATAGGTGTGCAAAT } \\
\text { CCATGCAAAACTGA }\end{array}$ & Transcription & IDT \\
\hline $\begin{array}{l}\text { T7-miR-92a-1 } \\
\text { template }\end{array}$ & $\begin{array}{c}\text { TAATACGACTCACTATAGGTATTGCACT } \\
\text { TGTCCCGGCCTGT }\end{array}$ & Transcription & IDT \\
\hline $\begin{array}{l}\text { Pri-miR-17-92 5 } \\
\text { Fwd }\end{array}$ & $\begin{array}{c}\text { TAATACGACTCACTATAGGAATTAATTG } \\
\text { CTGTTAGGAGGTTGGAAAATAGCAAAT } \\
\text { ATAG }\end{array}$ & Transcription & IDT \\
\hline $\begin{array}{l}\text { Pri-miR-17-92 5 } \\
\quad \text { Template }\end{array}$ & $\begin{array}{c}\text { TTAGGAGGTTGGAAAATAGCAAATATA } \\
\text { GATTTGGACGGTGGTAGTAATTTTGAG } \\
\text { CAAATAATGTTTTATCTTTTTTTTCCTTA } \\
\mathrm{T}\end{array}$ & Transcription & IDT \\
\hline $\begin{array}{l}\text { Pri-miR-17-92 5 } \\
\text { Rev }\end{array}$ & $\begin{array}{c}\text { AGGTCCACGTGTATGACTGGAATAGGG } \\
\text { AAAAATAAGGAAAAAAAAGATAAAACAT } \\
\text { TAT }\end{array}$ & Transcription & IDT \\
\hline
\end{tabular}




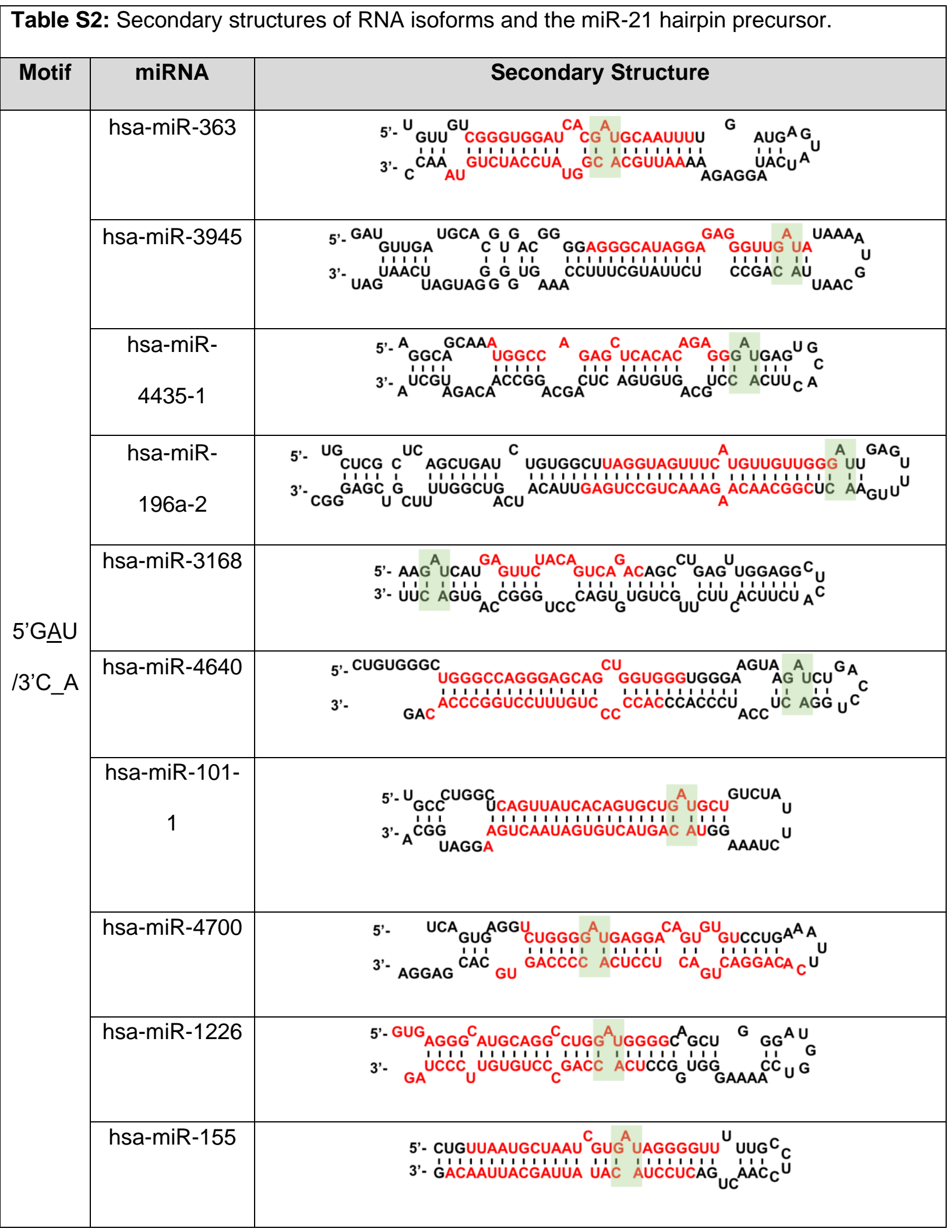




\begin{tabular}{|c|c|c|}
\hline & hsa-miR-4273 & 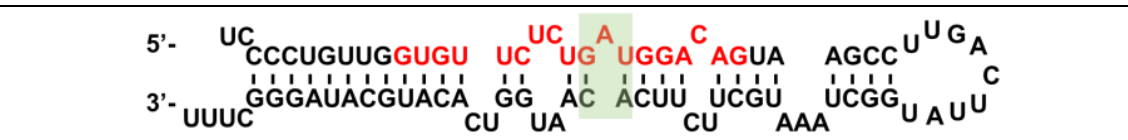 \\
\hline & hsa-miR-4454 & 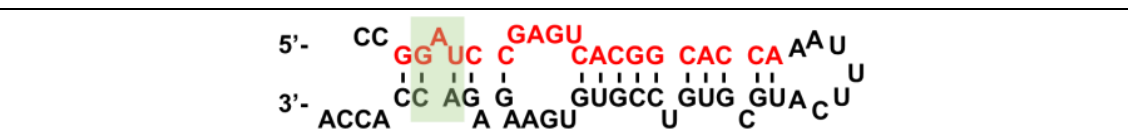 \\
\hline & $\begin{array}{l}\text { hsa-miR- } \\
4435-2\end{array}$ & 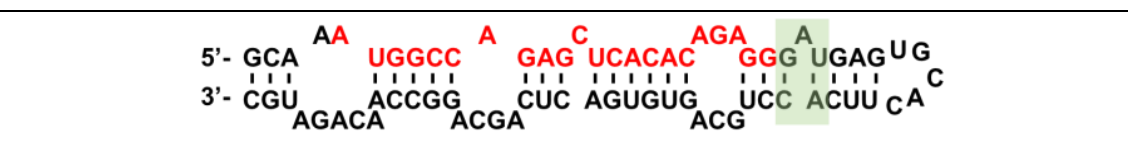 \\
\hline & hsa-let-7g & 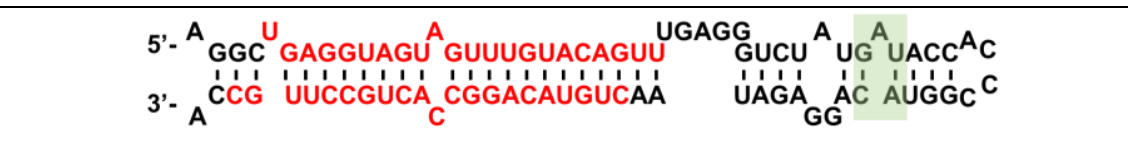 \\
\hline \multirow{7}{*}{$\begin{array}{c}5^{\prime} G_{-} U \\
13^{\prime} \mathrm{C} \underline{\mathrm{U}} \\
\mathrm{A}\end{array}$} & hsa-miR-539 & 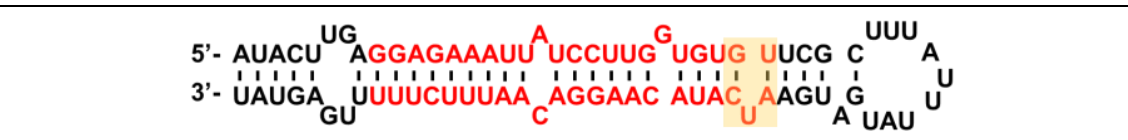 \\
\hline & hsa-miR-4267 & 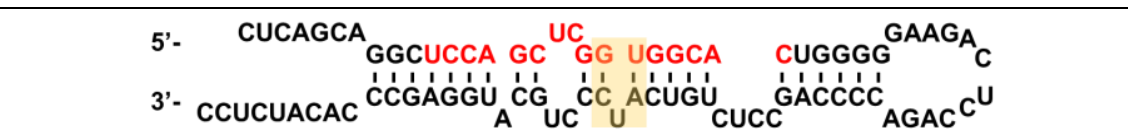 \\
\hline & hsa-miR-571 & 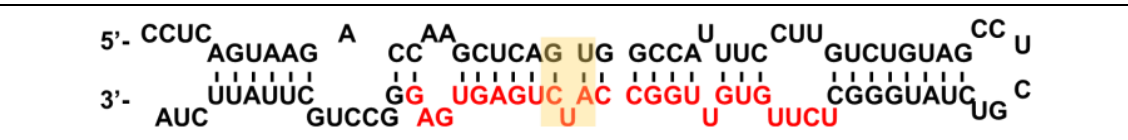 \\
\hline & $\begin{array}{l}\text { hsa-miR-153- } \\
1\end{array}$ & 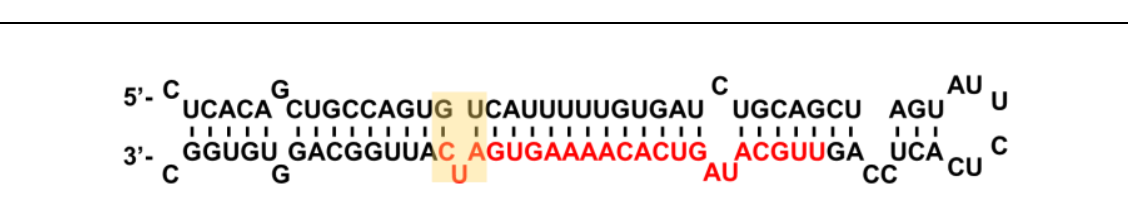 \\
\hline & $\begin{array}{l}\text { hsa-miR-153- } \\
2\end{array}$ & 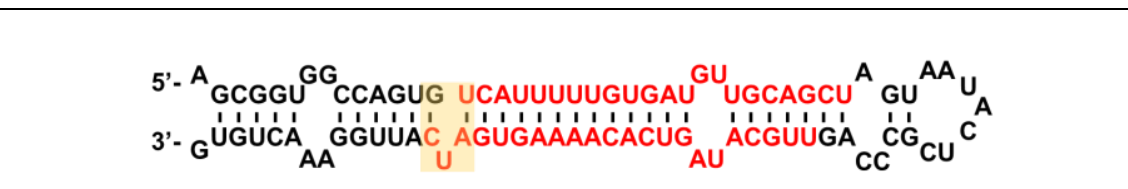 \\
\hline & hsa-miR-222 & 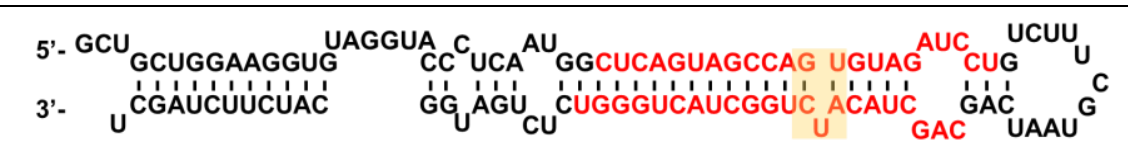 \\
\hline & $\begin{array}{c}\text { hsa-miR- } \\
\text { 3180-4 }\end{array}$ & 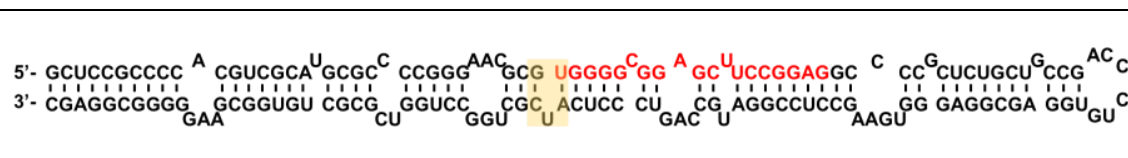 \\
\hline
\end{tabular}




\begin{tabular}{|c|c|c|}
\hline & $\begin{array}{l}\text { hsa-miR-19b- } \\
2\end{array}$ & 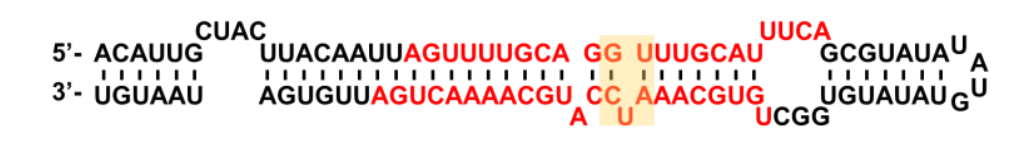 \\
\hline & hsa-miR-487a & 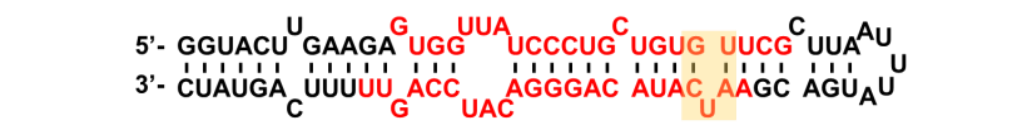 \\
\hline & hsa-miR-658 & 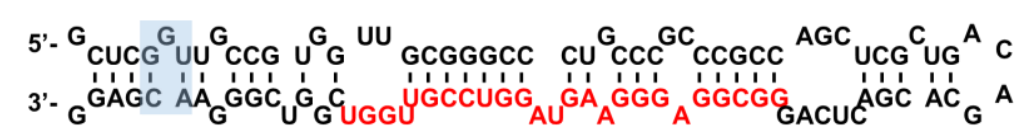 \\
\hline & hsa-miR-1197 & 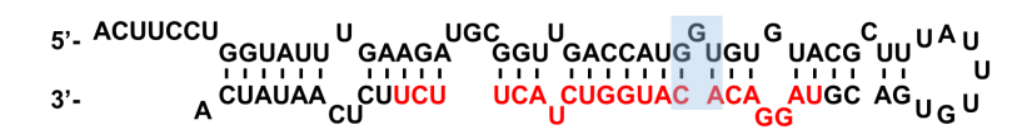 \\
\hline & hsa-miR-662 & 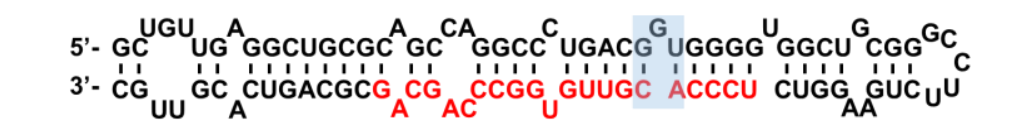 \\
\hline & hsa-miR-93 & 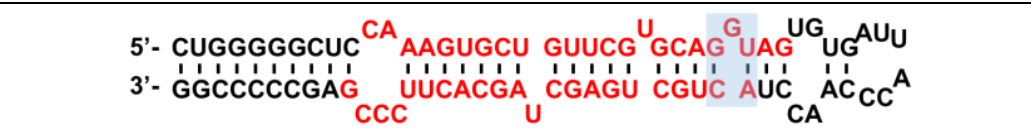 \\
\hline $\begin{array}{l}\text { 5'GㅁU } \\
\text { /3'C_A }\end{array}$ & $\begin{array}{l}\text { hsa-miR- } \\
548 a-2\end{array}$ & 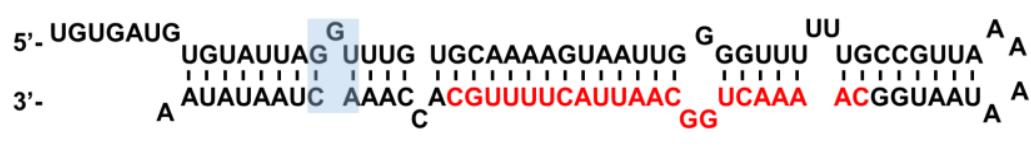 \\
\hline & hsa-miR-27b & 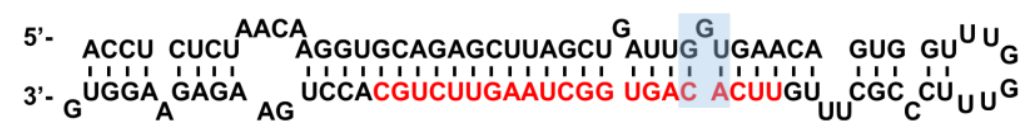 \\
\hline & hsa-miR-3178 & 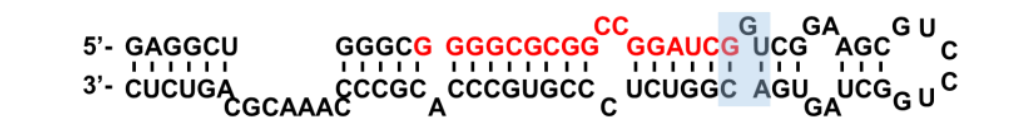 \\
\hline & hsa-miR-1324 & 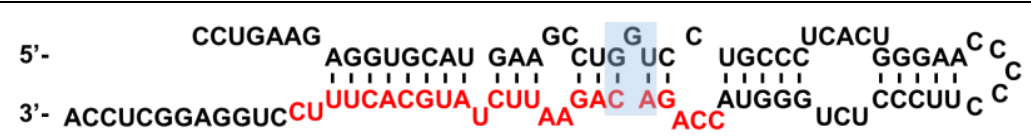 \\
\hline & hsa-miR-106a & 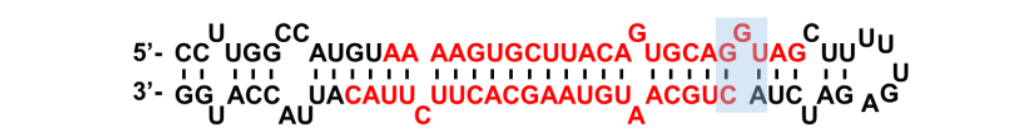 \\
\hline
\end{tabular}




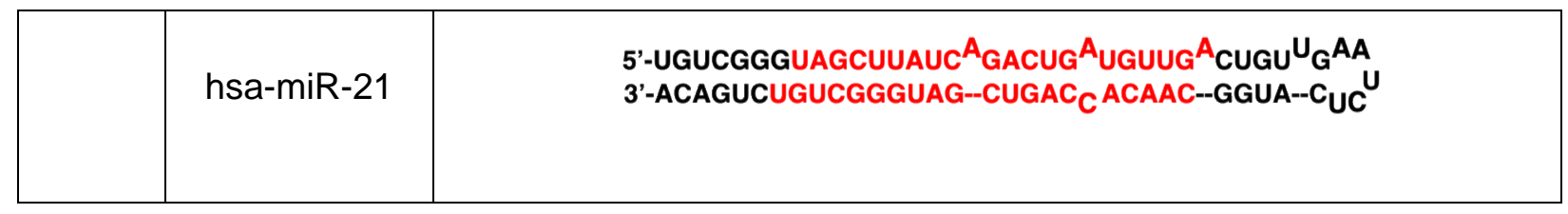

\section{Page S8}




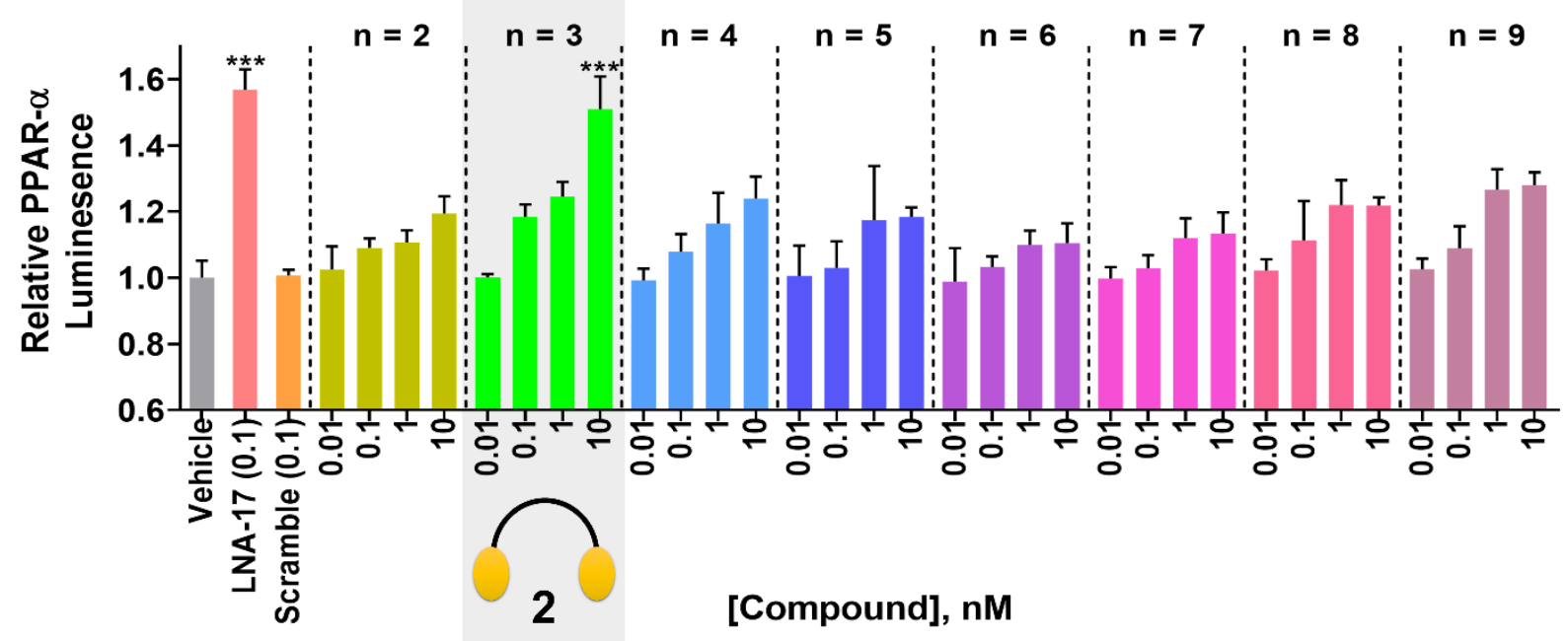

Figure S1: Screen of dimer library for de-repression of PPAR-a using a luciferase reporter. Screening a PPAR- $\alpha$ luciferase reporter for de-repression in MDA-MB-231 TNBC cells identifies a spacer length of $n=3(2)$ as the most optimal. Errors reported as S.E.M. ${ }^{* * *}, p<0.001$, as determined by a Student t-test 

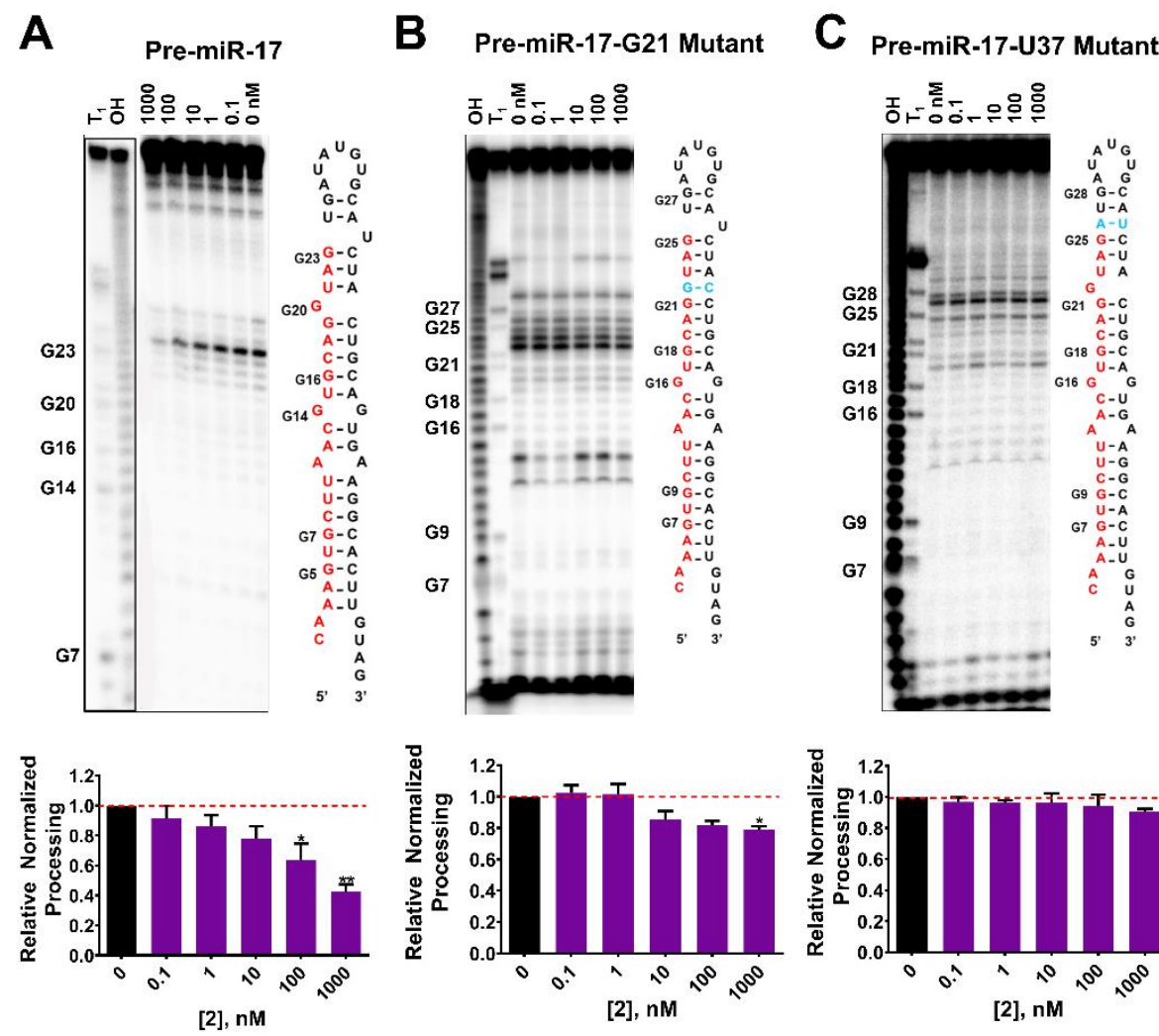

Pre-miR-17-G21/U37 Mutant
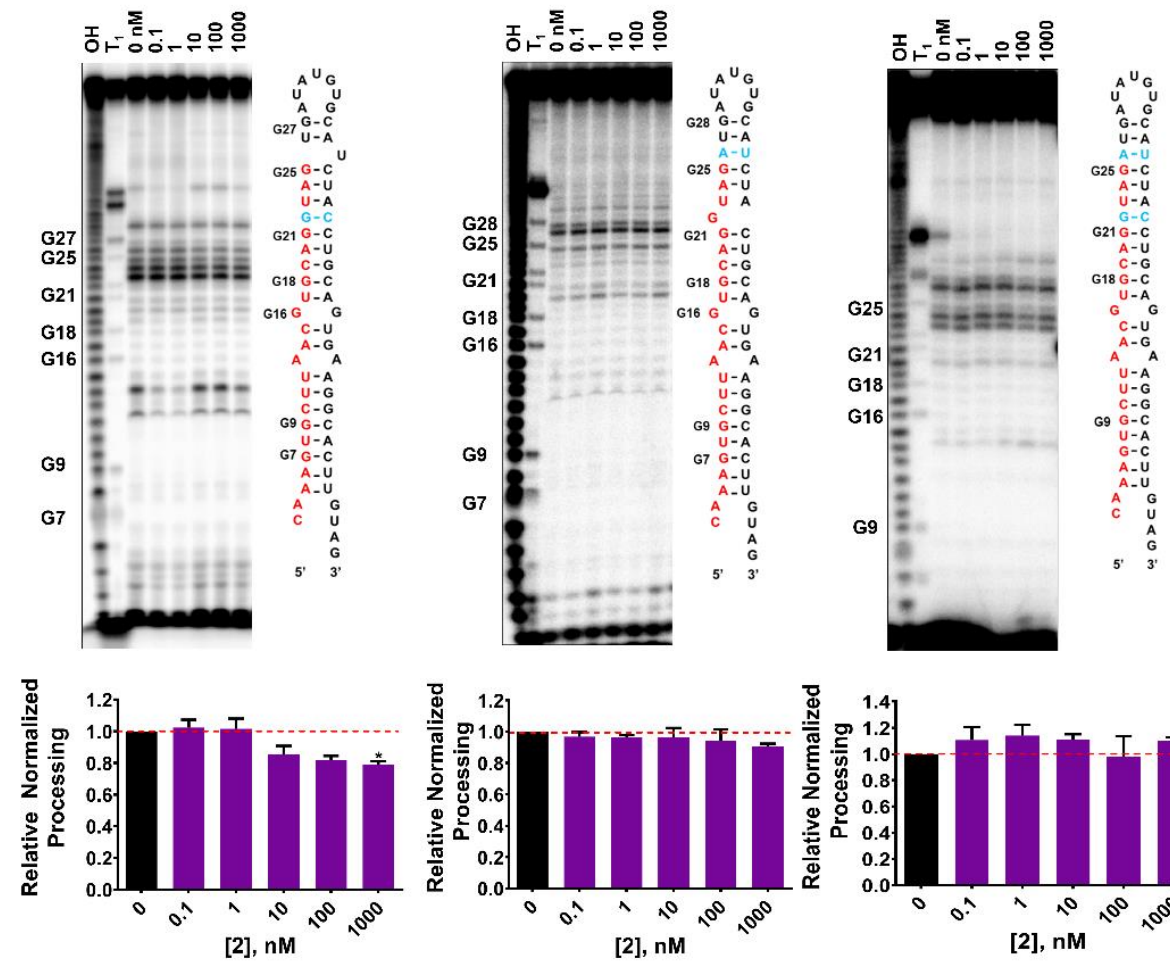

Figure S2: Inhibition of Dicer processing of pre-miR-17 and Mutants by 2 in vitro. A) Inhibition of in vitro Dicer processing of wild type pre-miR-17 by 2. B) Inhibition of in vitro Dicer processing of pre-miR-17-G21 mutant by 2. C) Inhibition of in vitro Dicer processing of pre-miR17-U37 mutant by 2. D) Inhibition of in vitro Dicer processing of pre-miR-17-G21/U37 mutant by 2. Errors reported as S.E.M. ${ }^{*}, p<0.05 ;{ }^{* *}, p<0.01$, as determined by a Student t-test. 

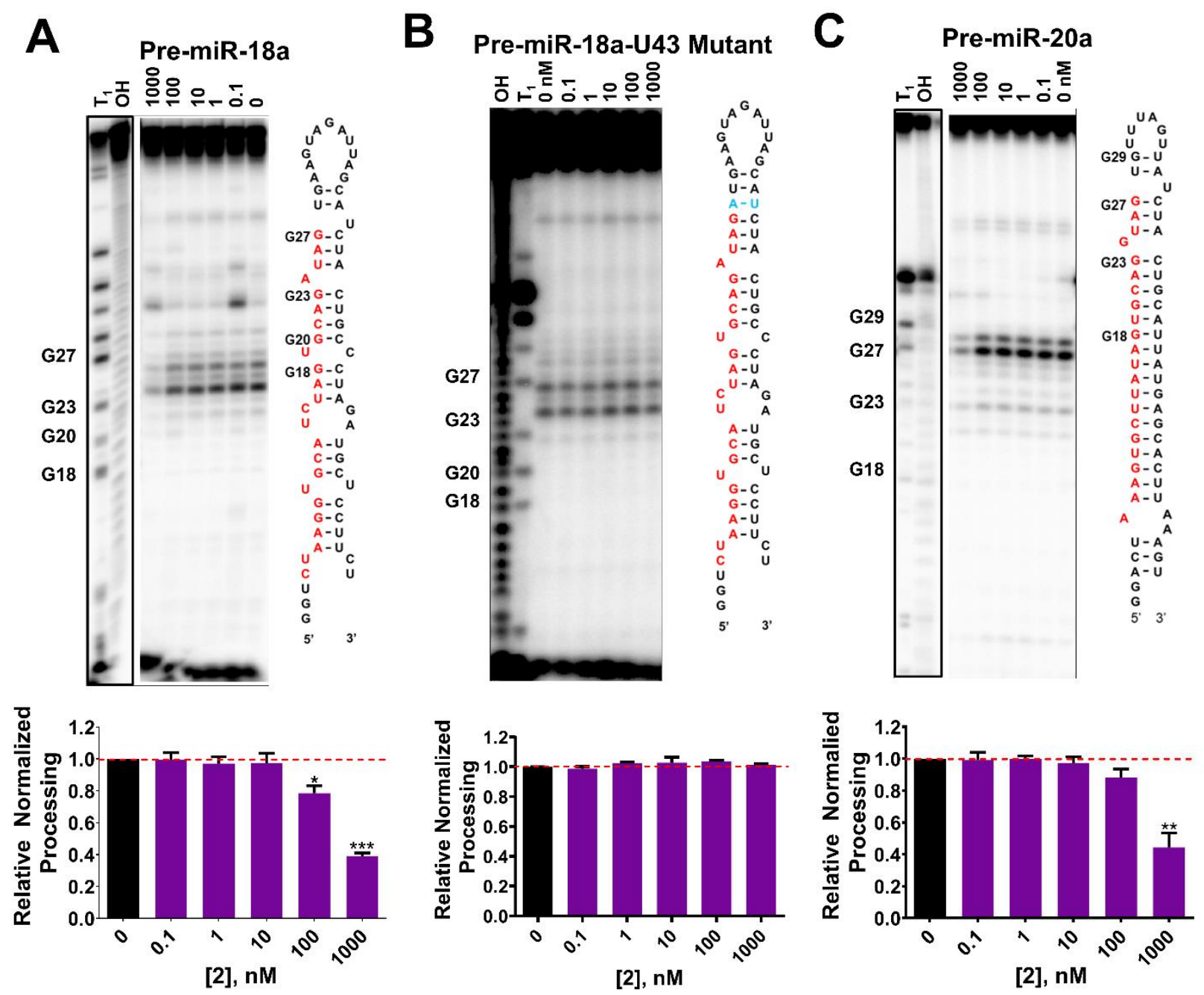

Figure S3: Inhibition of Dicer processing of pre-miR-18 and pre-miR-20a by 2 in vitro. A) Inhibition of in vitro Dicer processing of wild type pre-miR-18a by 2. B) Inhibition of in vitro Dicer processing of pre-miR-18a-U43 mutant by 2. C) Inhibition of in vitro Dicer processing of wild type pre-miR-20a by 2 . Errors reported as S.E.M. ${ }^{*}, p<0.05 ;{ }^{* *}, p<0.01$, as determined by a Student t-test. 
A

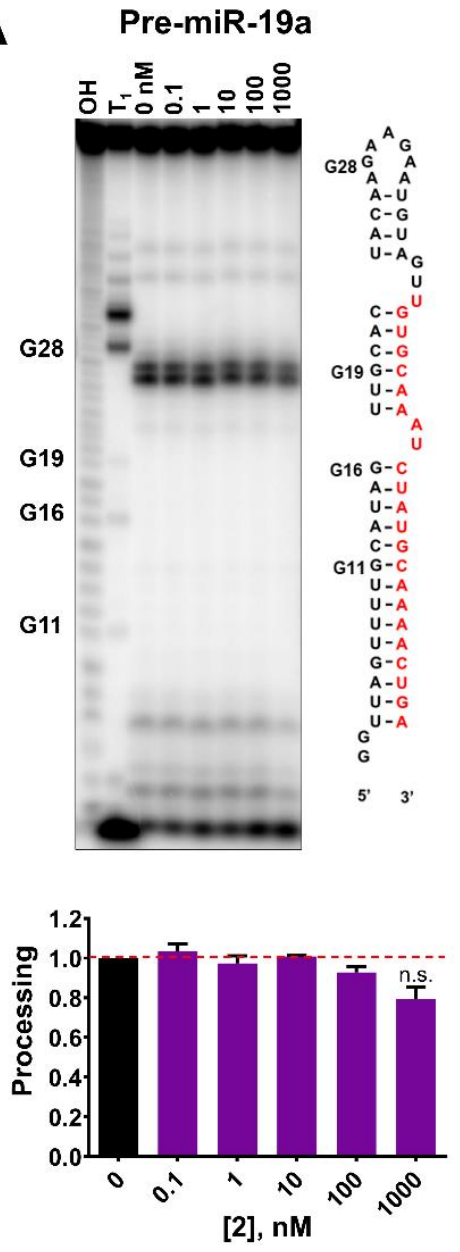

B Pre-miR-19b-1
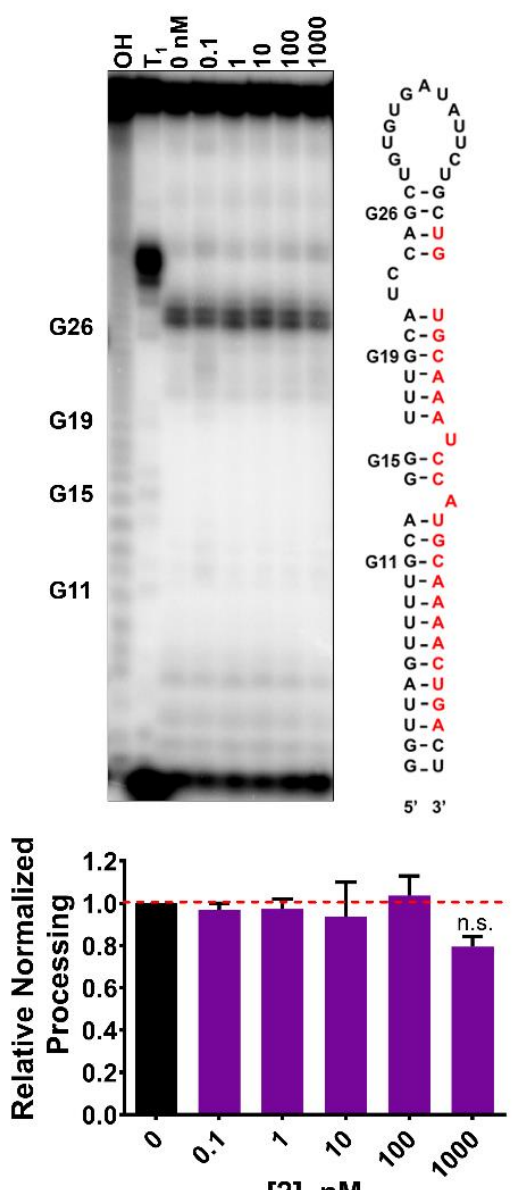

[2], $\mathrm{nM}$
C Pre-miR-92a-1
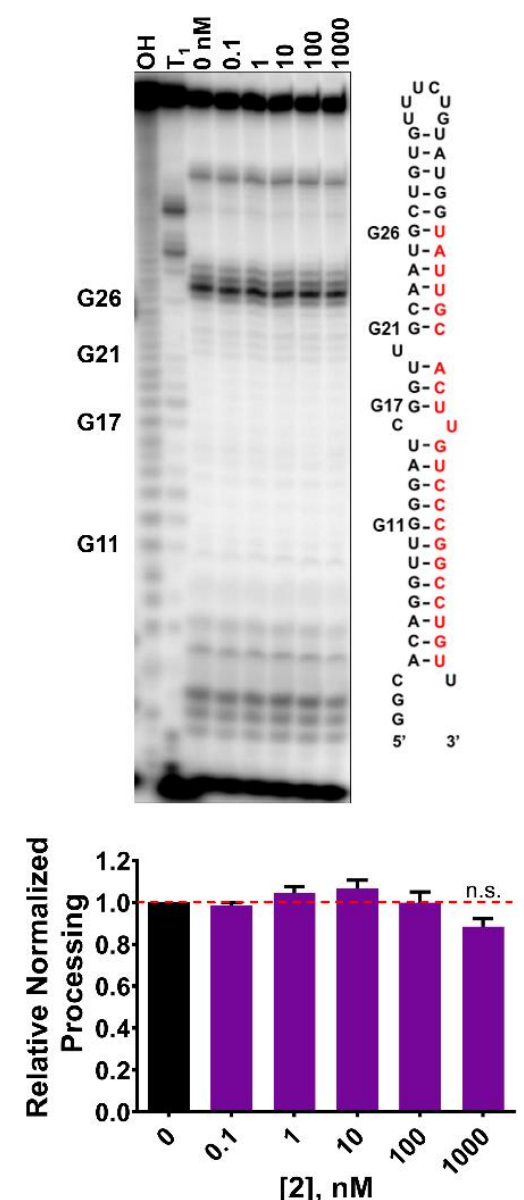

Figure S4: Inhibition of Dicer processing of pre-miR-19a, pre-miR-19b, and pre-miR-92a by 2 in vitro. A) Inhibition of in vitro Dicer processing of pre-miR-19b by 2. B) Inhibition of in vitro Dicer processing of pre-miR-19b-1 by 2. C) Inhibition of in vitro Dicer processing of pre-miR-92a by 2 . Errors reported as S.E.M. 


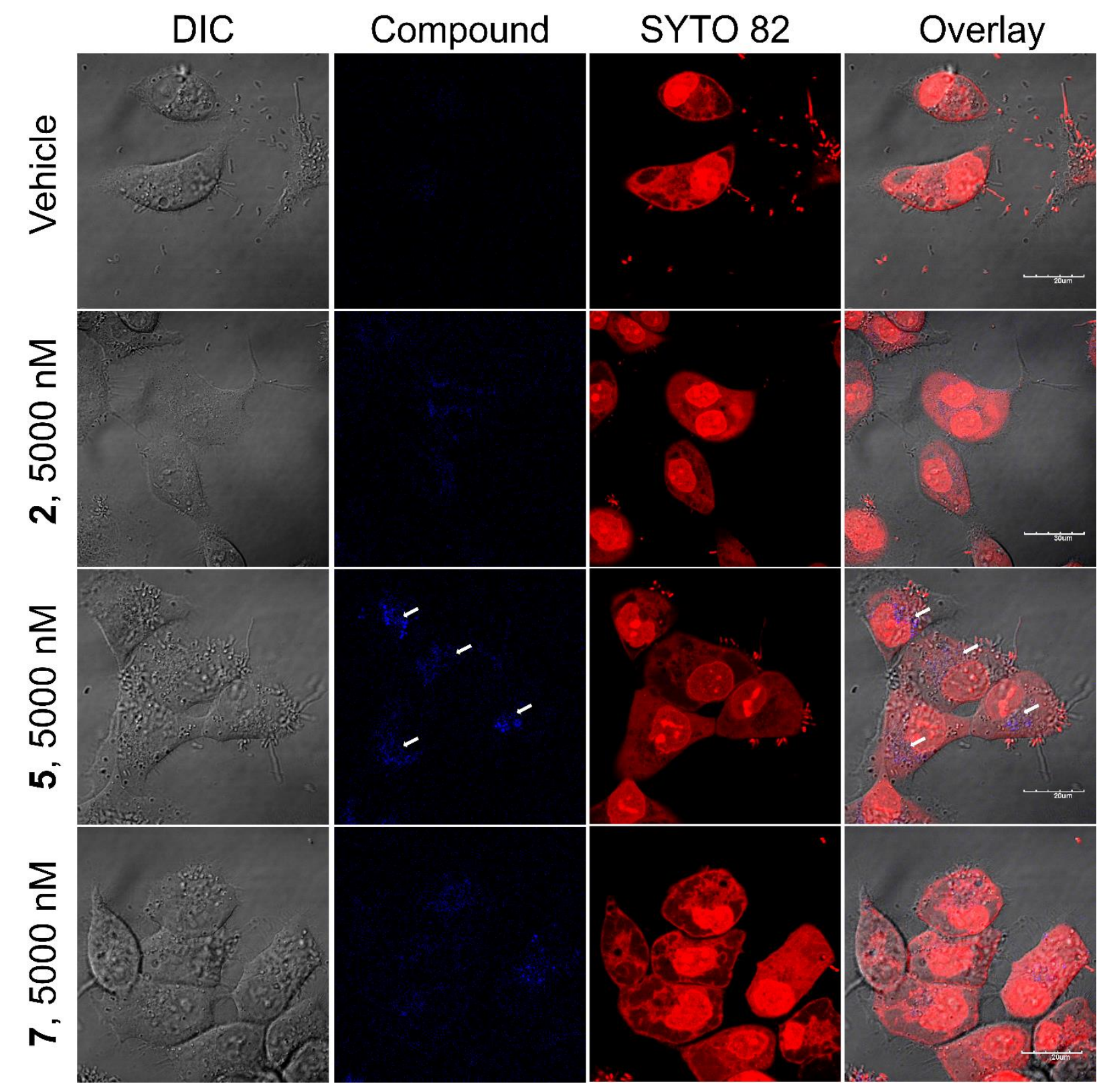

Figure S5: Representative microscopic images of the cellular uptake and localization of 2, 5, and 7 in DU145 cells. The images also show that all three compounds reside primarily in the cytoplasm with $\mathbf{5}$ also localizing to the perinuclear region (white arrows). 
A

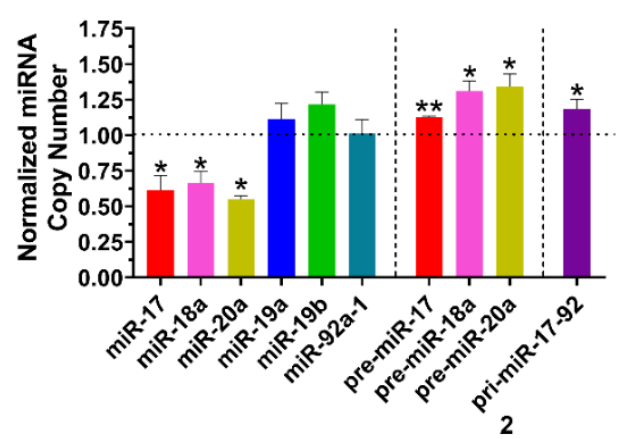

C
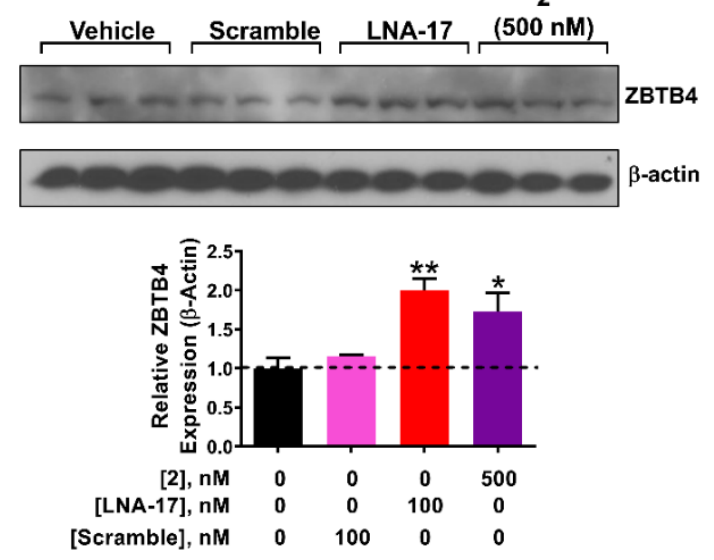

E
B
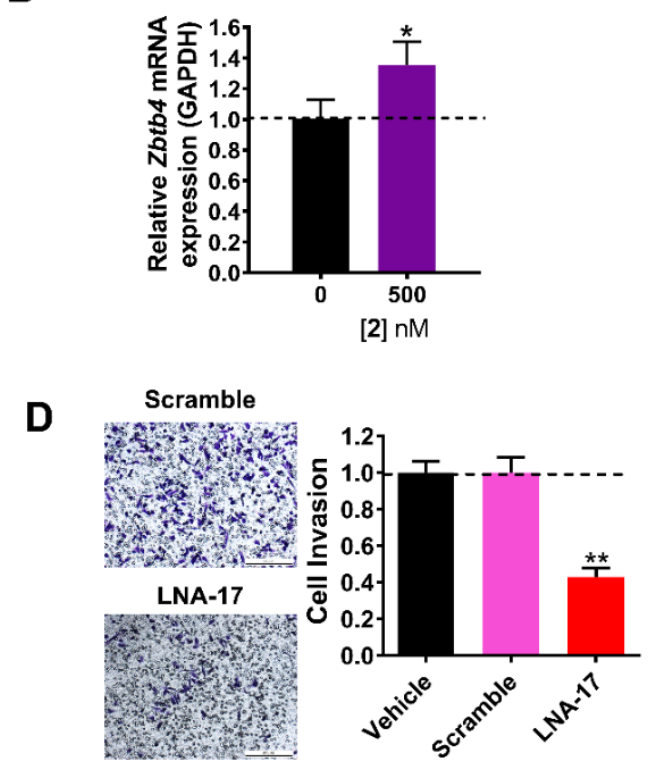

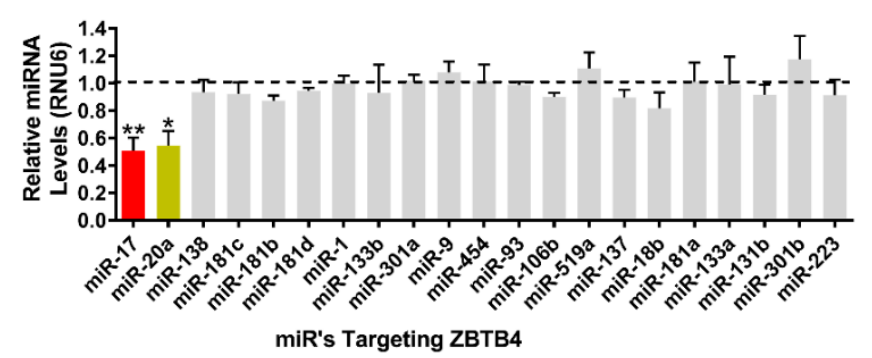

Figure S6: Depression of ZBTB4 mRNA and rescue of an invasive phenotype in MDA-MB-

231 cells by 2. A) Absolute quantification of mature, pre- and pri-miRs in the cluster corroborates our findings by relative qPCR analysis. B)Zbtb4 mRNA levels in MDA-MB-231 upon treatment with 2, as determined by RT-qPCR. C) Effect of 2 on ZBTB4 protein levels, as determined by Western blotting. D) Invasion of MDA-MB-231 cells upon treatment with a scrambled oligonucleotide control and LNA-17 (100 nM). E) Effect of 2 treatment on the levels of other miRNAs predicted by TargetScan to modulate Zbtb4, as determined by RT-qPCR. Errors reported as S.E.M. *,$p<0.05 ;{ }^{* *}, p<0.01$, as determined by a Student $t$ test. 
A
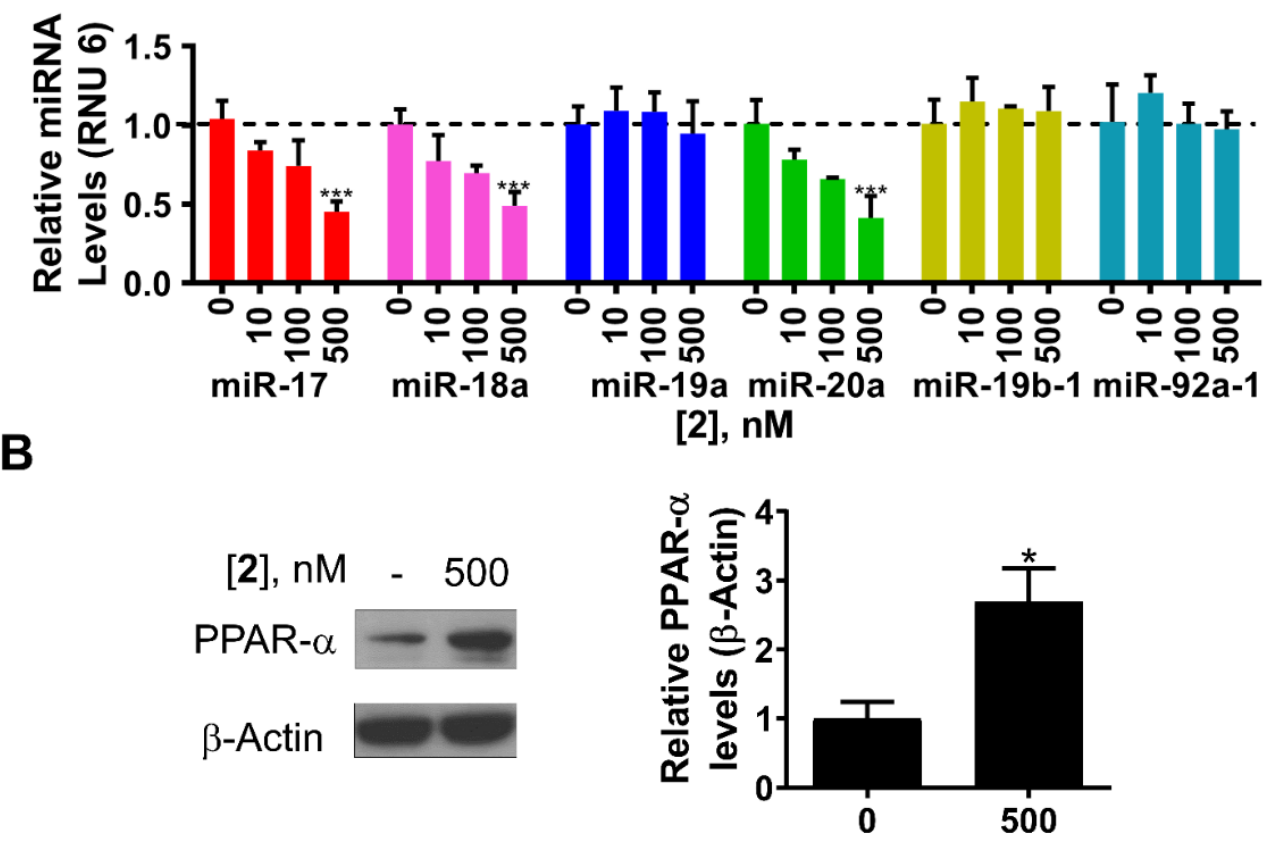

[2], $\mathrm{nM}$

Figure S7: Effect of 2 on the expression of miRNAs in miR-17-92 cluster in WT 9-12 cells. A) Levels of mature miRNAs in the 17-92 cluster in WT-9-12 upon treatment of 2, as determined by RT-qPCR. B) Western blot of PPARa shows de-repression of protein upon treatment with compound 2 by $\sim 2.5$-fold. Errors reported as S.E.M. ${ }^{*}, \mathrm{p}<0.05$, as determined by a Student $\mathrm{t}$ test. 
A

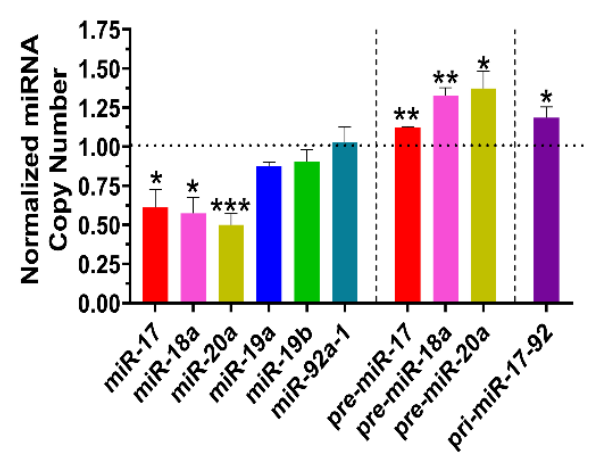

B

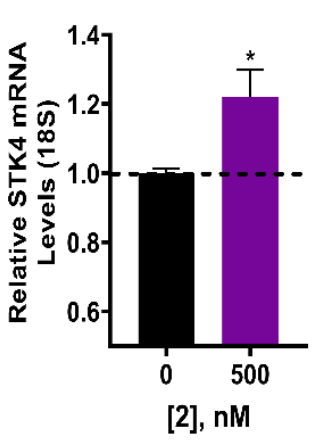

C
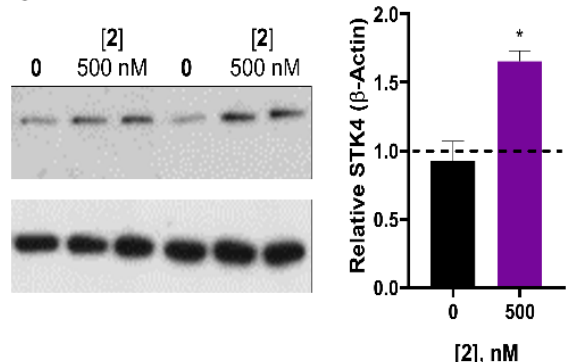

D

E
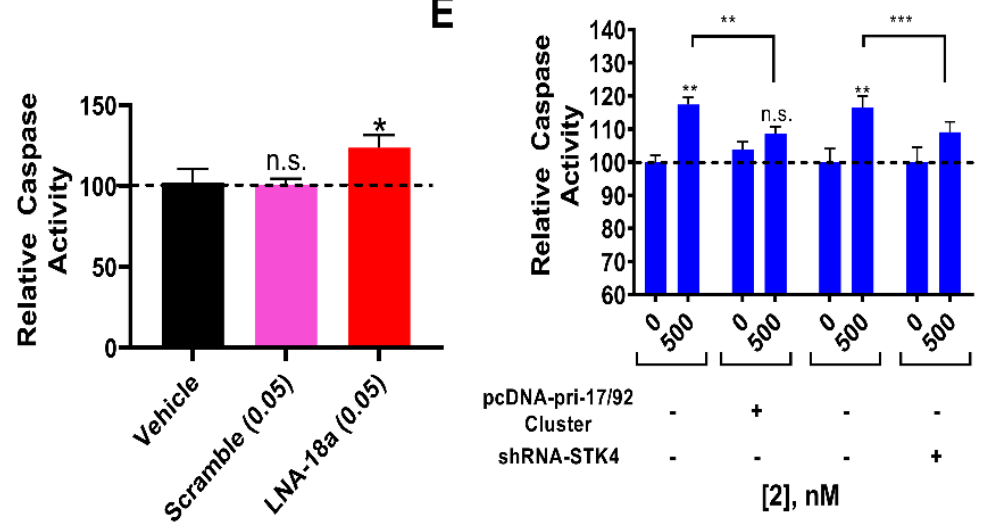

Figure S8: Effect of 2 on levels of miR-18a's direct target, STK4 mRNA and induction of Caspase $3 / 7$ activity in DU-145 cells. A) Absolute quantification of mature, pre- and pri-miRNAs in the cluster, as determined by RT-qPCR. B) Effect of 2 on Stk4 mRNA levels, as determined by RT-qPCR. C) Effect of 2 on STK4 protein levels, a direct target of miR-18a. D) Effect of a pool of an antagomiR directed at miR-18a (LNA-18a) and a scrambled oligonucleotide control on Caspase 3/7 activity. E) Effect of overexpressing the miR-17-92 cluster or knocking out Stk4 mRNA with an shRNA on 2's ability to induce Caspase 3/7 activity. Errors reported as S.E.M. " $p<0.05,{ }^{* *}, p<0.01,{ }^{* * *}, p<0.001$, as determined by a Student $t$ test. 

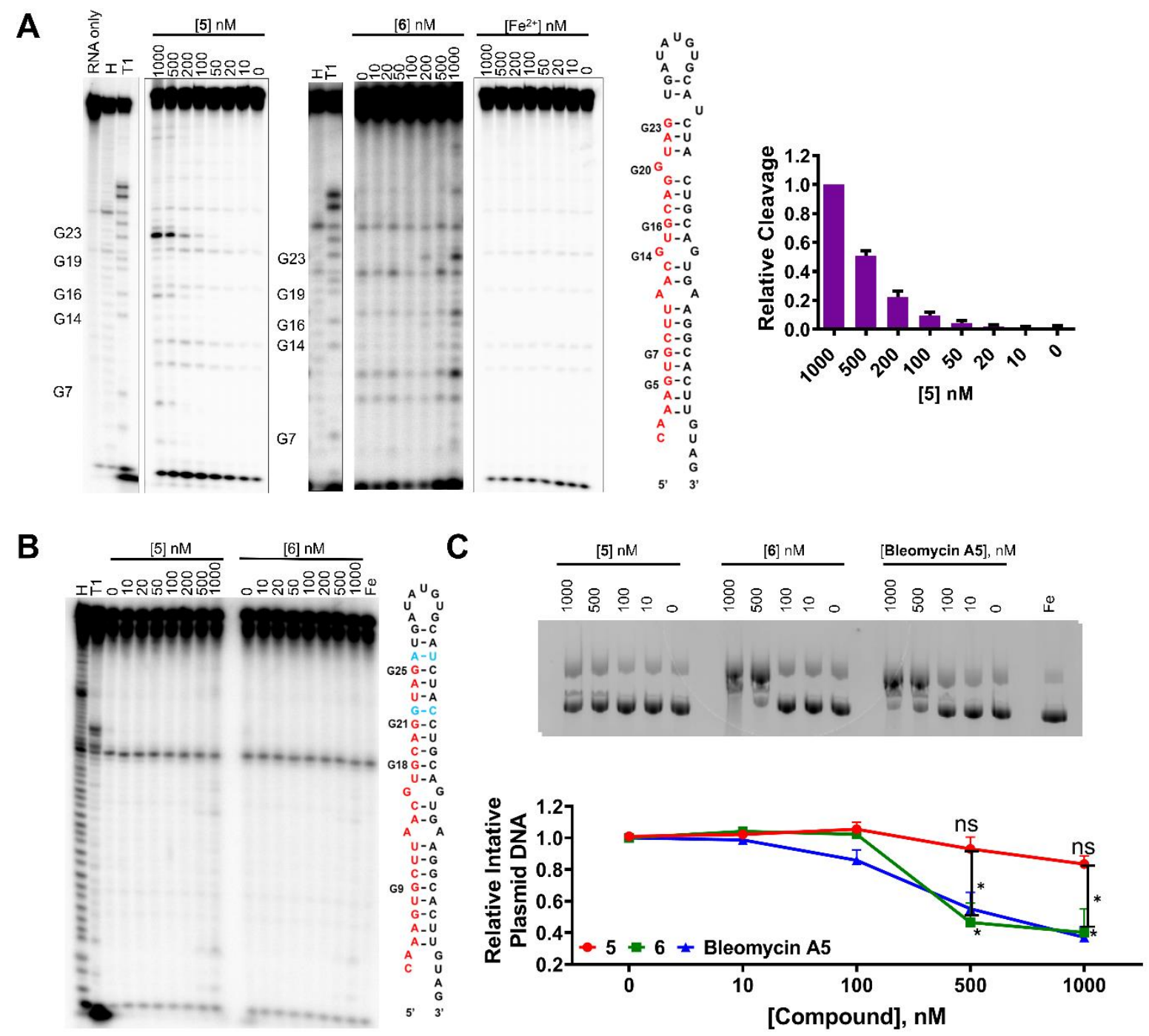

Figure S9. In vitro cleavage of pre-miR-17, mutant pre-miR-17-BP, and DNA by 5 or 6 . A) In vitro cleavage of pre-miR-17 by 5 and $\mathbf{6}$ and an Iron (II) only control. Compound $\mathbf{5}$ cleaves premiR-17 (left gel) near the Dicer site while 6 has no clear cleavage pattern (middle gel). Iron (II) has no effect (right gel). B) In vitro cleavage of mutant pre-miR-17 by $\mathbf{5}$ or $\mathbf{6}$ with shows no effect of either compound as the binding motifs are absent. C) Cleavage of plasmid DNA by 5, 6, or bleomycin A5 in vitro. Errors reported as S.E.M. ${ }^{*}, \mathrm{p}<0.05$, as determined by a Student t-test. 
A
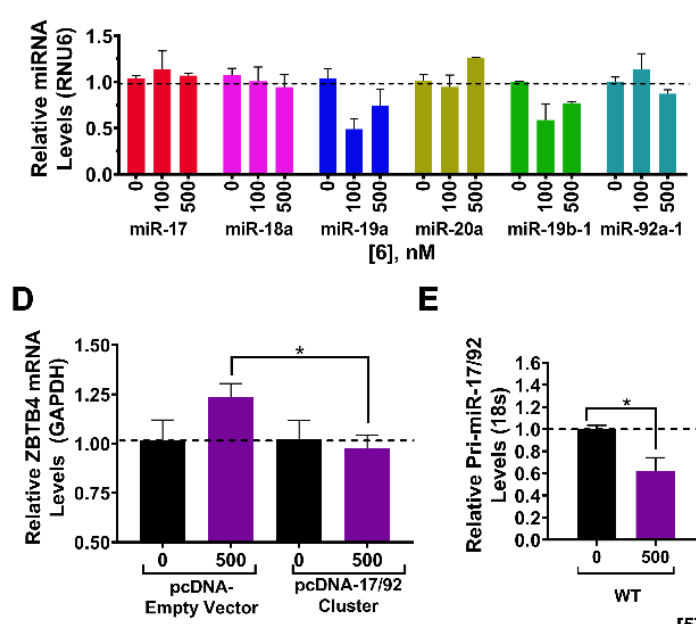

[5], nM
B

E

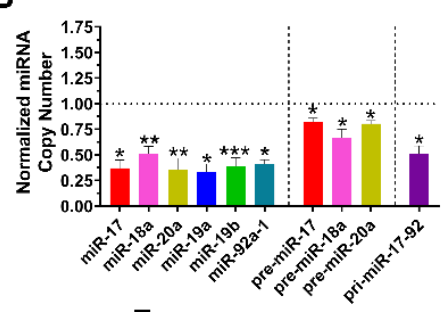

$F$

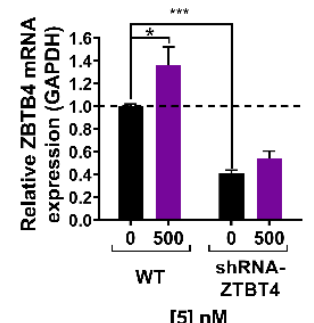
[5] $\mathrm{nM}$
C

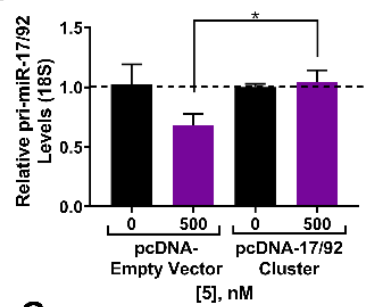

G

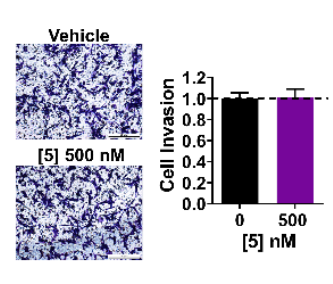

[5] nM

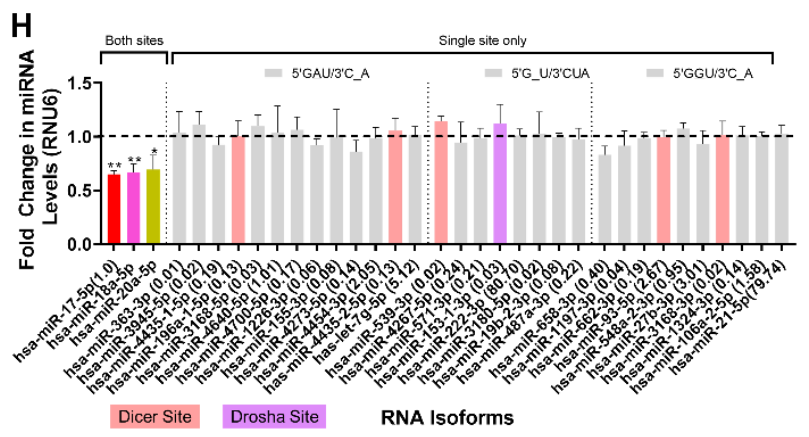

Figure S10: Effects of 5 and 6 in MDA-MB-231 TNBC cells. A) Levels of mature miRNAs from the 17-92 cluster upon treatment with 6 (lacks RNA-binding modules), as determined by RTqPCR. B) Absolute quantification of mature, pre- and pri-miRNAs in the cluster, as determined by RT-qPCR. C - D) Overexpression of the miR-17-92 cluster in MDA-MB-231 cells ablated 5's knockdown of pri-miR-17-92 and de-repression of Zbtb4 mRNA levels. E) pri-miR-17-92 levels in MDA-MB-231 cells overexpressing a shZBTB4 show no effect on 5's cleavage of pri-miR-1792. F) Effect of $\mathbf{5}$ on Zbtb4 mRNA levels in MDA-MB-231 cells expressing shZBTB4, as determined by RT-qPCR. G) Effect of $\mathbf{5}$ on the invasive properties of MDA-MB-231 cells that express shZBTB4 cells. H) Effect of 5 on miRNAs that share bulges bound by $\mathbf{1}$ (RNA isoforms) and miR-21. Errors reported at S.E.M ${ }^{*}, \mathrm{p}<0.05,{ }^{* *}, \mathrm{p}<0.01,{ }^{* * *}, \mathrm{p}<0.001$ by a Student $\mathrm{t}$ test. 
A

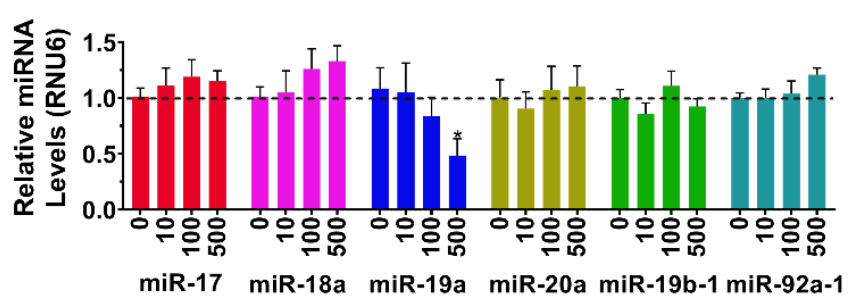

[6], nM

C

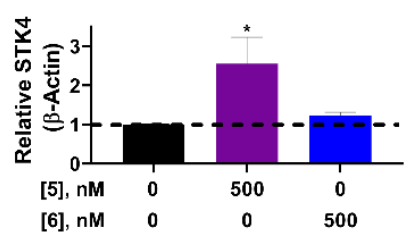

E

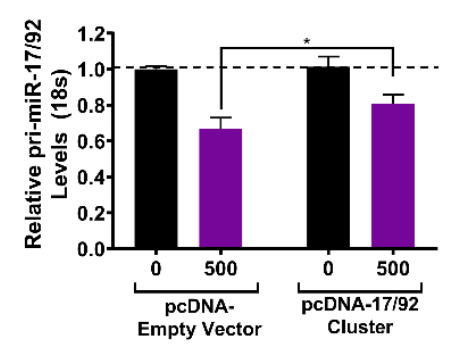

[5], $\mathrm{nM}$

H

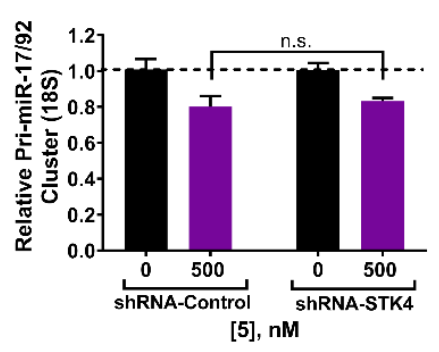

$\mathrm{K}$

[5], nM

[5], nM
B

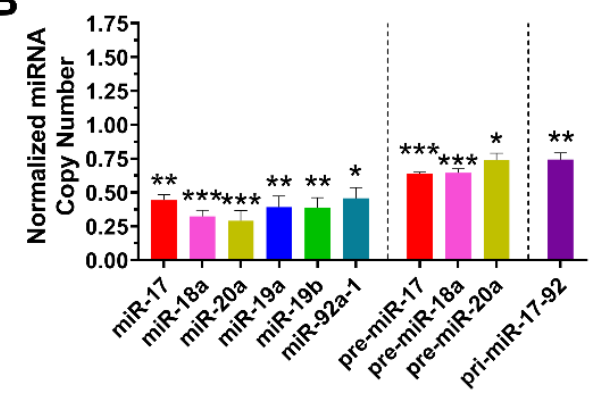

D

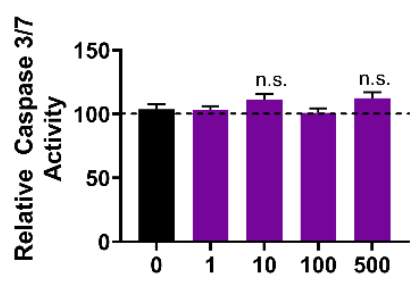

[6], nM

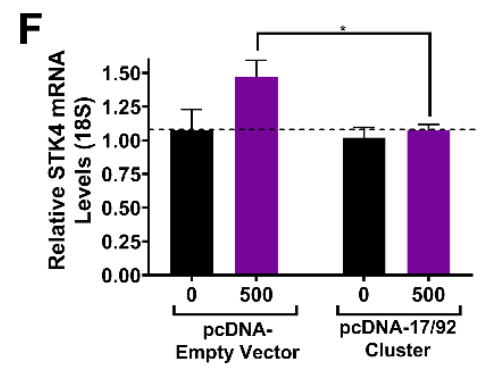

G

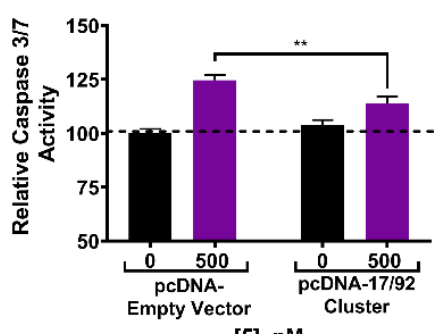

[5], nM

J

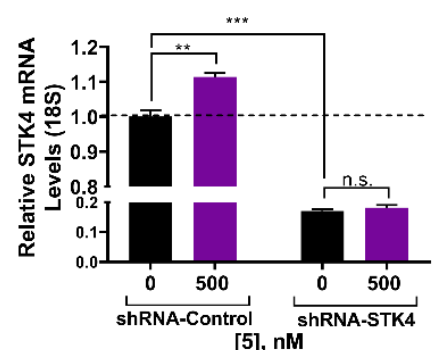

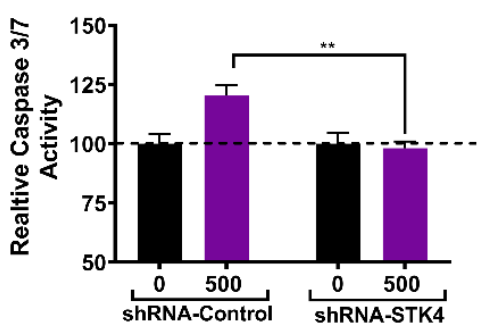

[5], nM

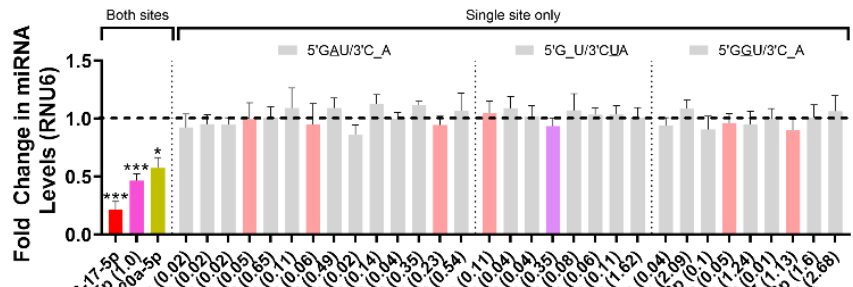

Dicer Site Drosha Site RNA Isoforms 
Figure S11: Effects of 5 and 6 in DU145 cells. A) Levels of mature miRNAs from the 17-92 cluster upon treatment with 6 (lacks RNA-binding modules), as determined by RT-qPCR. The reduction in miR-19a levels is likely due to its stretches of AU pairs, known to be cleaved preferentially by bleomycin A5. ${ }^{1}$ B) Absolute quantification of mature, pre- and pri-miRNAs in the cluster, as determined by RT-qPCR. C) Western blot of STK4 protein levels in DU145 cells treated with $\mathbf{5}$ and 6. D) Effect of $\mathbf{6}$ on Caspase 3/7 activity DU145 cells. $\mathbf{E}-\mathbf{F}$ ) Effect of $\mathbf{5}$ on pri-miR-17-92 and Stk4 mRNA levels in DU145 cells overexpressing the miR-17-92 cluster, as determined by RT-qPCR. G) Effect of 5 on Caspase 3/7 activity in DU145 cells overexpressing the cluster. $\mathbf{H}-\mathbf{I}$ ) Effect of 5 on pri-miR-17-92 and Stk4 mRNA levels in DU145 cells expressing a shRNA targeting Stk4 mRNA. J) Effect of 5 on Caspase 3/7 activity in DU145 cells expressing a shRNA targeting Stk4 mRNA. K) Effect of 5 on miRNAs that share bulges bound by 1 (RNA isoforms) and miR-21. Errors reported at S.E.M. ${ }^{*}=p<0.05,{ }^{* *}=p<0.01,{ }^{* * *}=p<0.001$ by a Student $t$ test. 


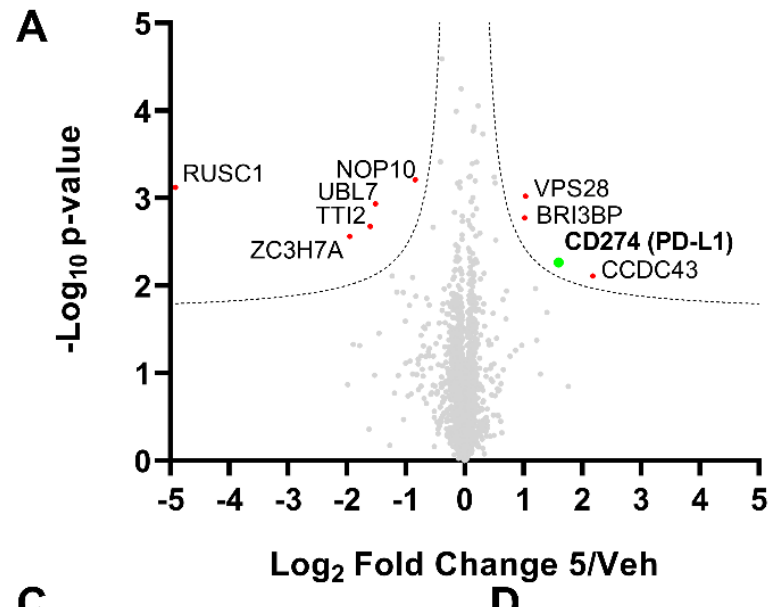

C

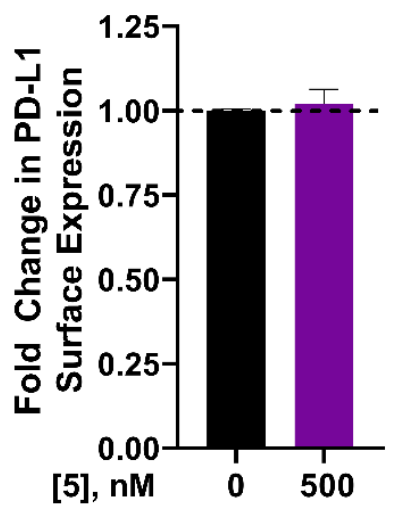

B

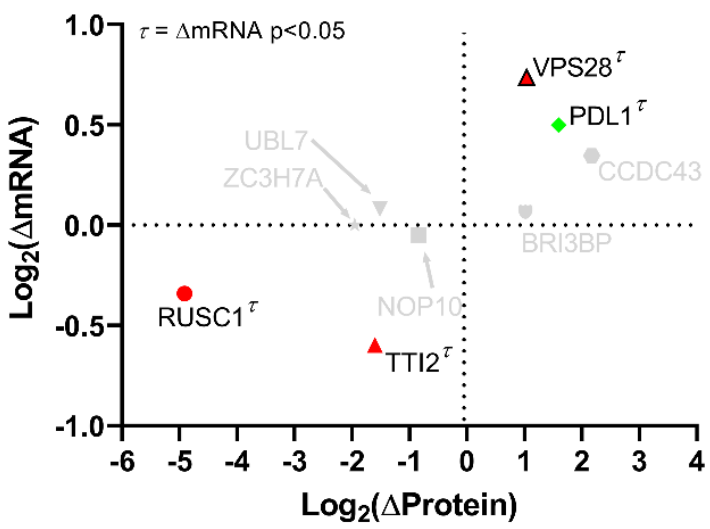

$\mathbf{E}$

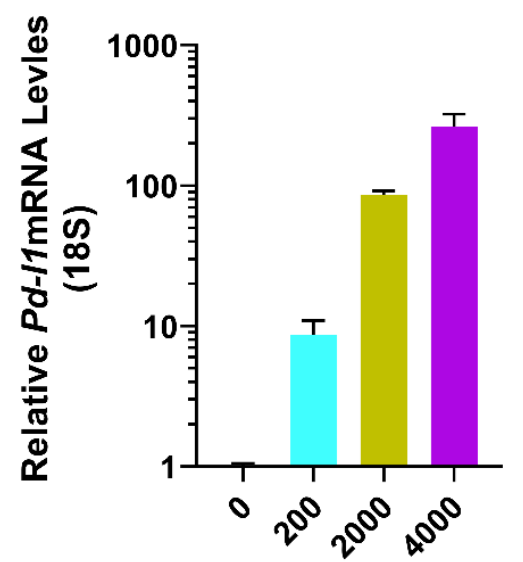

Plasmid, ng

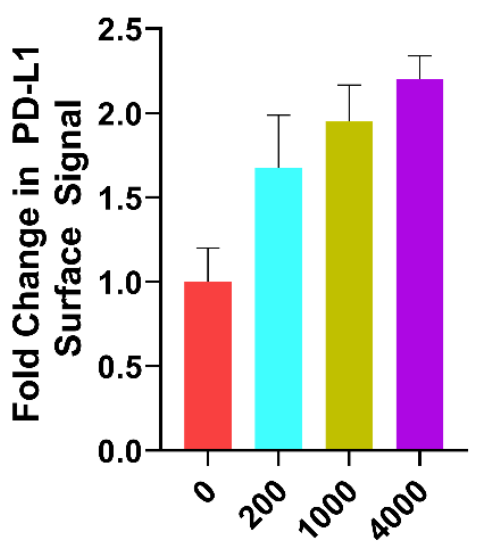

Plasmid, ng

Figure S12: Global protein expression changes in DU-145 cells treated with 5. A) Volcano plot of the global proteome in DU-145 cells treated with $\mathbf{5} \mathrm{vs}$. vehicle, as determined by LC-MS/MS analysis. Data are represented as $\log _{2}$ fold change; dotted lines represent a false discovery rate of $1 \%$ and an S0 of 0.1 [where S0 is the minimum fold change required to be considered for significance], collectively an adjusted p-value of 0.01 . Colored dots represent proteins $(n=9)$ significantly changed in response to treatment with 5. B) Comparison of fold-change in protein levels, as determined by proteomics analysis, as a function of fold-change in the encoding mRNAs, as determined by RT-qPCR. Of these, only VPS28, PD-L1, RUSC1, and TTI2 showed significant changes in their mRNA that correlated with the observed change in protein expression levels. 
Notably, programmed cell-death ligand 1 (PD-L1 or CDC274) is upregulated, which is a known target of miR-17 and miR-20a. PD-L1 (CD274) is a known target of miR-17; thus, its upregulation is expected $(\sim 40 \%)$. C) Treatment with $\mathbf{5}$ has no significant increase in PD-L1 surface expression as measured by FACS. RT-qPCR (D) and FACS (E) analyses of DU-145 cells that overexpress PD-L1. The protein PD-L1 binds to its cognate receptor programmed cell death 1 (PD-1) to control T-cell activation. Cancer cells have increased surface levels of PD-L1 to evade T-cell mediated immune responses. ${ }^{2-3}$ However, this marker is challenging to target with ADC's due to either insufficient surface enhancement and its expression on other tissues. ${ }^{4,5}$ Increasing surface levels of PD-L1 may be a viable strategy to make this marker amenable for ADC mediated therapies. FACS analysis of DU-145 cells treated with 5, showed no significant increase in PD-L1 surface levels. We next studied how much of an increase in PD-L1 mRNA is needed to change surface levels significantly. An increase of 10-fold of PD-L1 mRNA is required to cause a $50 \%$ increase in cell surface expression. This suggests that $\mathbf{5}$, while it can de-repress PD-L1, cannot achieve a high enough increase in gene expression to alter surface levels. These do however support that 5 is indeed engaging the miR-17-92 cluster since PD-L1 is a downstream target of miR-17 and miR-20a. Errors reported as S.E.M. 
A

MDA-MB-231

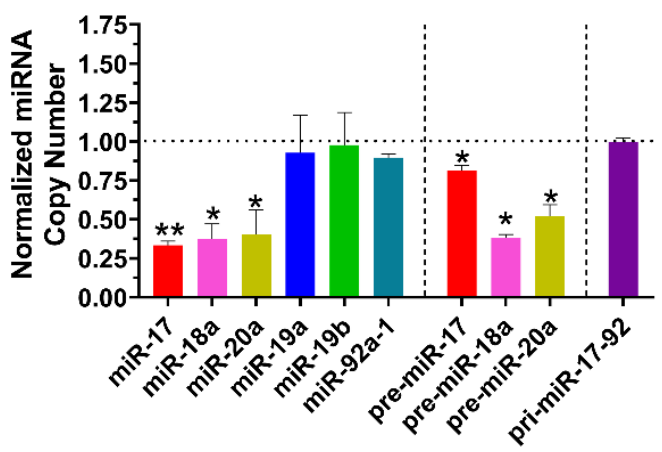

B

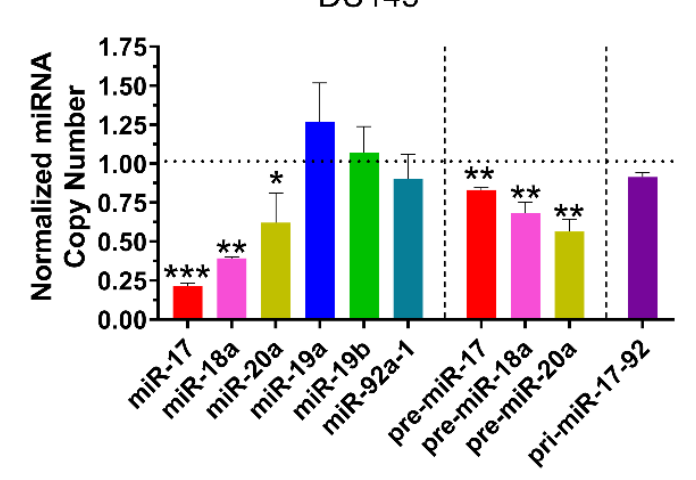

Figure S13: Absolute quantification of Mature, precursor and primary miR-17-92 cluster in DU145 and MDA-MB-231 for RIBOTAC (7). A) Absolute quantification of mature, pre- and primiR-17-92 shows similar effects by 7 in MDA-MB-231 cells corroborating the relative quantification data observed previously. B) Absolute quantification of mature, pre- and pri-miR17-92 shows similar effects by 7 in DU-145 cells corroborating the relative quantification data observed previously. All errors reported as S.E.M *, $p<0.05 ;{ }^{* *}, p<0.01 ;{ }^{* *}, p<0.001$ by a Students T-test. 


\section{Supplemental Methods:}

General Methods. Synthetic RNAs were obtained from Dharmacon. They were deprotected according to the manufacturers protocol and de-salted using PD-10 sephadex columns (GE Healthcare) per the manufacturers protocol. DNA templates and primers were obtained from IDT and used without further purification. Locked Nucleic Acid inhibitors were purchased from Exiqon and resuspended in TE buffer directly. HEK 293T, MDA-MB-231 and DU145 cells were obtained from ATCC and used directly. HEK-293T and WT-9-12 cells were maintained in 1× DMEM (Corning) supplemented with $1 \times$ glutaGRO (Corning-) Penicillin/Streptomycin $(50 \mathrm{U} / \mathrm{mL})$ and $10 \%$ (v/v) fetal bovine serum (Sigma) [growth medium]. Proper adherence of WT-9-12 cells required coating of dishes with PurCol Bovine collagen $3 \mathrm{mg} / \mathrm{mL}$ (Corning) at $3{ }^{\circ} \stackrel{\circ}{\mathrm{C}}$ for $30 \mathrm{~min}$ before seeding cells. MDA-MB-23 and DU145 cells were maintained in 1× RPMI 1640 (Corning) supplemented with Penicillin/Streptomycin $(50 \mathrm{U} / \mathrm{mL})$ and $10 \%$ Fetal Bovine Serum (Sigma) [growth medium]. All cells were grown at $37^{\circ} \mathrm{C}$ with $5 \% \mathrm{CO}_{2}$. Chemicals were purchased from the following commercial sources: Combi blocks, Advanced Chem Tech, and Alfa Aesar.

Luciferase assays. HEK $293 \mathrm{~T}$ cells were plated in six-well dishes $\left(2 \times 10^{5}\right.$ cells per well $)$ and cotransfected with $0.4 \mathrm{mg}$ of pLS-Renilla-30-UTR plasmids and with $0.04 \mathrm{mg}$ of the pGL3-Control plasmid using jetPrime per the manufacture's protocol for $4 \mathrm{~h}$. Then, the cells were trypsinized and plated into 96-well plates $\left(2^{*} 10^{4}\right.$ cells per well) and allowed to adhere for $12 \mathrm{~h}$ after which, they were treated with the Dimer library or vehicle (DMSO) for $24 \mathrm{~h}$. After treatment, Firefly and Renilla luciferase activities were measured by using the Dual-Luciferase Reporter Assay System (Promega Corp) according to the manufacturer's directions. Luminescence was measured on a Molecular Devices M5 plate reader with an integration time of $500 \mathrm{~ms}$.

Binding Affinity Measurements. An in-solution fluorescence-based assay was used to determine the binding affinities of the best dimer to miR-17 and -18 a by monitoring the change in fluorescence intensity of 4-FL as a function of RNA concentration. Briefly, the RNA of interest Page S24 
was folded in $1 \times$ Folding Buffer ( $8 \mathrm{mM} \mathrm{Na}_{2} \mathrm{HPO}_{4}, \mathrm{pH} 7.0,185 \mathrm{mM} \mathrm{NaCl}$, and $1 \mathrm{mM} \mathrm{EDTA}$ ) at 60 ${ }^{\circ} \mathrm{C}$ for $5 \mathrm{~min}$ and then slowly cooled to room temperature. Then, the 4-FL was added into the RNA solution to a final concentration of $100 \mathrm{nM}$. Serial dilutions were completed using $1 \times$ Folding Buffer supplemented with $100 \mathrm{nM}$ 4-FL compound. The solutions were incubated at room temperature for $30 \mathrm{~min}$ and then transferred to a black 384-well plate. Fluorescence intensity was measured using a Bio-Tek FL×800 plate reader with an excitation bandpass filter of 485/20 nm and an emission band pass filter of $528 / 20 \mathrm{~nm}$. The change in fluorescence intensity as a function of the concentration of RNA was fit to equation 1 :

$l=l_{0}+0.5 \Delta \varepsilon\left\{\left([\mathrm{FL}]_{0}+[\mathrm{RNA}]_{0}+K_{d}\right)-\left(\left([\mathrm{FL}]_{0}+[\mathrm{RNA}]_{0}+K d\right)^{2}-4[\mathrm{FL}]_{0}[\mathrm{RNA}]_{0}\right)^{1 / 2}\right\}$

where $I$ is the observed fluorescence intensity; $I_{0}$ is the fluorescence intensity in the absence of RNA; $\Delta \varepsilon$ is the difference between the fluorescence intensity in the absence of RNA and in the presence of infinite RNA concentration; $[F L]_{0}$ is the concentration of compound; $[R N A]_{0}$ is the concentration of the selected RNA; and $K_{d}$ is the dissociation constant. Competitive binding assays were completed by incubating the RNA of interest with $100 \mathrm{nM} \mathrm{4-FL}$ and increasing concentrations of 2 . The resulting curves were fit to equation 2 :

$\theta=1 / 2[C]\left[K_{-} t+K_{-} t / K_{-} d\left[C_{-} t\right]+[R N A]+[C]\right]-\left\{\left(K_{-} t+K_{-} t / K_{-} d+\left[C_{-} t\right]+[R N A]+[C]\right)-\right.$ $4[C][R N A]\}$

where $\theta$ is the percentage of 4-FL bound, [4-FL] is the concentration of 4-FL, $\mathrm{Kt}$ is the dissociation constant of RNA and 4-FL, [RNA] is the concentration of RNA, Ct is the concentration of 4-FL, $K_{d}$ is the dissociation constant for $\mathbf{4}$, and $\mathrm{A}$ is a constant.

Dicer Inhibition assay. The RNA was folded in $1 \times$ Reaction Buffer (Genlantis) by heating at 60 ${ }^{\circ} \mathrm{C}$ for $5 \mathrm{~min}$ and slowly cooling to room temperature. The samples were then supplemented with $1 \mathrm{mM} \mathrm{ATP}$ and $2.5 \mathrm{mM} \mathrm{MgCl}_{2}$. Serially diluted concentrations of 2 were added, and the samples were incubated at room temperature for $15 \mathrm{~min}$. Next, $7 \mathrm{ng} / \mu \mathrm{L}$ of recombinant human Dicer was 
added followed by incubation at $37^{\circ} \mathrm{C}$ overnight. Reactions were stopped by adding the manufacturer's supplied stop solution (Genlantis). A T1 ladder (cleaves G residues) was generated by heating the RNA in 1× RNA Sequencing Buffer (20 mM sodium citrate, $\mathrm{pH} 5.0,1$ $\mathrm{mM}$ EDTA, and $7 \mathrm{M}$ urea) at $55^{\circ} \mathrm{C}$ for 10 min followed by slowly cooling to room temperature. RNase $T 1$ was then added to a final concentration of $10 \mathrm{U} / \mu \mathrm{L}$, and the solution was incubated at room temperature for 20 min. An RNA hydrolysis ladder was generated by incubating RNA in 1x RNA Hydrolysis Buffer ( $50 \mathrm{mM} \mathrm{NaHCO}_{3}, \mathrm{pH} 9.4$, and $1 \mathrm{mM} \mathrm{EDTA}$ ) at $95{ }^{\circ} \mathrm{C}$ for $5 \mathrm{~min}$ the sample was then snap cooled on ice. In all cases, the cleavage products were separated on a $0.7 \mathrm{~mm}$ denaturing $15 \%$ polyacrylamide gel and imaged using a Bio-Rad PMI phosphorimager.

RT-qPCR in DU145, MDA-MB-231, and WT-9-12 cells. DU145 cells were seeded into 12-well plates at $\sim 50 \%$ confluency ( $\approx 200,000$ cells $/$ well) and allowed to adhere for $12 \mathrm{~h}$. After adhering, the cells were treated with compounds $\mathbf{2}, \mathbf{5 , 6}$, or $\mathbf{7}(10,100$, and $500 \mathrm{nM})$ for $24 \mathrm{~h}$. Total RNA was then harvested using a Zymo-Quick RNA Mini prep kit (Zymo Research) with DNase treatment according in the manufacturers protocol. Reverse transcription (RT) for mature miRNAs was done using the miScript II RT kit (Qiagen) with $200 \mathrm{ng}$ of total RNA. To measure precursor and mRNA levels, RT was done using qScript (Quanta Bio) according to the manufacturers protocol on $1000 \mathrm{ng}$ of total RNA. RT-qPCR was carried out on an Applied Biosystems $7900 \mathrm{HT}$ cycler under standard conditions (2 step PCR; $60 \stackrel{\circ}{\mathrm{C}}$ annealing/elongation, $95 \stackrel{\circ}{\circ}$ melt) using the Power Sybr Master Mix (Applied Biosystems). Data were normalized to RNU6 for mature miRNAs and 18S ribosomal RNA for precursor miRNA's and mRNAs, with expression levels calculated using the $\Delta \Delta \mathrm{Ct}$ method. ${ }^{6}$ Similar to what was done in DU145 cells, MDA-MB-231 and WT-9-12 cells were cultured in 6 well or 12-well plates and treated with compounds $\mathbf{2}, \mathbf{5 , 6}$, or $\mathbf{7}$ for $24 \mathrm{~h}$. Total RNA was extracted in a similar manner and subjected to RT-qPCR as described above. RT for precursor and mRNAs in MDA-MB-231 cells was done using the High Flex buffer in the miScript II RT kit. 
Western blotting. Cells were grown in 6 -well plates to $\sim 50 \%$ confluency in complete growth medium and then incubated with $500 \mathrm{nM}$ of 2 or $\mathbf{5}$ for $48 \mathrm{~h}$. Total protein was extracted using MPER Mammalian Protein Extraction Reagent (Pierce Biotechnology) supplemented with 1x Protease Inhibitor cocktail (Roche). Extracted total protein was quantified using a Micro BCA Protein Assay Kit (Pierce Biotechnology). Approximately $10 \mu \mathrm{g}$ of total protein was resolved using an $8 \%$ SDS-polyacrylamide gel and then transferred to a PVDF membrane for $80 \mathrm{~min}$ at $350 \mathrm{~mA}$ current (25 mM Tris, pH 8.5, $200 \mathrm{mM}$ glycine and 20\% (v/v) Methanol). The membrane was briefly washed with 1× Tris-buffered saline (TBS; $50 \mathrm{mM}$ Tris-Cl, pH 7.5. $150 \mathrm{mM} \mathrm{NaCl}$ ) and blocked with $5 \%$ milk in $1 \times$ TBST (1x TBS containing $0.05 \%$ Tween-20) for $1 \mathrm{~h}$ at room temperature. The membrane was then incubated with 1:1000 ZBTB4 primary antibody (Life Technologies) in $1 \times$ TBST containing $5 \%$ milk overnight at $4{ }^{\circ} \mathrm{C}$. The membrane was washed with 1× Tris Buffered a Saline with 0.1\% Tween-20 (TBST: $20 \mathrm{mM}$ Tris-Base pH 7.6; $150 \mathrm{mM}$ $\mathrm{NaCl}, 0.1 \%(\mathrm{v} / \mathrm{v})$ Tween-20) and incubated with 1:2000 antirabbit IgG horseradish-peroxidase (Cell Signaling) secondary antibody conjugate in $1 \times$ TBST for $1 \mathrm{~h}$ at room temperature. After washing with $1 \times$ TBST, protein expression was quantified using SuperSignal West Pico Chemiluminescent Substrate (Pierce Biotechnology) per the manufacturer's protocol and exposed to X-Ray film. The membrane was then stripped using $1 \times$ Stripping Buffer (200 mM glycine, $1 \%$ Tween-20, and $0.1 \%$ SDS, $\mathrm{pH} 2.2$ ) followed by washing in $1 \times$ TBST. The membrane was blocked and probed for $\beta$-actin following the same procedure described above using 1:5000 $\beta$-actin primary antibody (Cell Signaling) in $1 \times$ TBST containing $5 \%$ milk overnight at $4{ }^{\circ} \mathrm{C}$. The membrane was washed with $1 \times$ TBST and incubated with 1:10,000 anti-rabbit IgG horseradishperoxidase secondary antibody conjugate (Cell Signaling) in $1 \times$ TBST for $1 \mathrm{~h}$ at room temperature. ImageJ software from the National Institutes of Health was used to quantify band intensities. 
Using a similar method as mentioned above, STK4 (MST-1) levels were investigated in DU145 cells. Approximately $10 \mu \mathrm{g}$ of protein was resolved on a $12.5 \%$ Bis-Tris polyacrylamide gel pH 6.8 with a $4 \%$ Bis-Tris pH 6.8 stacking layer at $150 \mathrm{~V}$ in $1 \times$ Running Buffer (50 mM MOPS, $50 \mathrm{mM}$ Tris, $\mathrm{pH} 7.7,1 \mathrm{mM}$ EDTA, and 1\% (w/v) SDS). The proteins were transferred to a PVDF membrane using the wet transfer method at $350 \mathrm{~mA}$ for $1 \mathrm{~h}$. Membranes were blocked with $1 \times$ TBST containing 5\% milk and then probed with 1:400 of Rabbit anti-Human STK4 (Cell Signaling - D889Q) overnight in TBST with 5\% Milk followed by washing and probing with 1:5000 antirabbit-HRP (Cell Signaling) for $2 \mathrm{~h}$ at room temp. Bands were visualized as mentioned earlier. After stripping, $\beta$-Actin was probed as described earlier, and imaged. PD-L1 was probed in a similar manner using 1:1000 Rabbit anti-Human PD-L1 (Cell Signaling- E1L3N®) and 1:5000 antirabbit HRP.

Caspase 3/7 Glo Assay. DU145 cells were seeded into 96-well black clear bottom plates (Corning - 89091-014) at $50 \%$ confluency $(\approx 20,000$ cells/well) and allowed to adhere overnight. The cells were then treated with $\mathbf{2 , 5}$, or $\mathbf{6}$ at $1,10,100$, and $500 \mathrm{nM}$ or LNAs targeting the cluster and a Scrambled LNA at $50 \mathrm{nM}$ for $24 \mathrm{~h}$. LNAs were obtained from Qiagen with the miRCURY Power LNA backbone and uptake tag, and were treated to the cells directly without transfection. Caspase 3/ 7 activity was measured by using the Caspase $3 / 7$ glow reagent (Promega) according to the manufacturers protocol. Luminescence was measured on a Molecular Devices M5 plate reader with an integration time of $500 \mathrm{~ms}$.

Invasion assay. A Boyden chamber assay was used to assess invasion of MDA-MB-231 cells. Transwell inserts were coated with $100 \mu \mathrm{L}$ of $0.5 \mathrm{mg} / \mathrm{mL}$ Matrigel (Fisher Scientific: CB40234) diluted with serum free growth media at $37^{\circ} \mathrm{C}$ for $30 \mathrm{~min}$. MDA-MB-231 cells $\left(5 \times 10^{4}\right)$ pre-treated with vehicle, LNA, Scramble $\mathbf{2}$ or $\mathbf{5}$ in serum free growth medium were seeded at the upper chamber with complete growth medium at the bottom. After incubating at $37^{\circ} \mathrm{C}$ for $16 \mathrm{~h}$, medium in the bottom wells and inserts was removed. The inserts and bottom wells were washed twice 
with PBS and excess liquid was removed with cotton swabs. To the bottom well was added 400 $\mu \mathrm{L}$ of $4 \%$ paraformaldehyde and incubated at room temperature for $20 \mathrm{~min}$. The wells and inserts were washed twice with PBS and then stained for $20 \mathrm{~min}$ by adding $400 \mu \mathrm{L}$ of $0.1 \%$ (w/v) crystal violet solution (dissolved in $4 \%$ aqueous $\mathrm{MeOH}$ ). The wells and inserts were washed twice with water and twice with $1 \times$ PBS. After drying, the invaded cells were imaged using a Leica DMI3000 B upright fluorescent microscope and counted manually.

In vitro Bleomycin cleavage assay. The template used for pre-miR17(TCAAAGTGCTTACAGTGCAGGTAGTGATATGTGCATCTACTGCAGTGAAGGCACTTGTA GC) was PCR-amplified in 1×PCR Buffer, $2 \mu \mathrm{M}$ forward primer(GGCCGGATCCTAATACGACTCACTATAGGTCAAAGTGCTTACAGTGCAGG), $2 \mu \mathrm{M}$ reverse primer(GCTACAAGTGCCTTCACTG), $4.25 \mathrm{mM} \mathrm{MgCl} 2,330 \mu \mathrm{M}$ dNTPs, and $2 \mu \mathrm{L}$ of Taq DNA polymerase in a $50 \mu \mathrm{L}$ reaction. Cycling conditions were $95^{\circ} \mathrm{C}$ for $30 \mathrm{~s}, 55^{\circ} \mathrm{C}$ for $30^{\circ} \mathrm{C}$, and $72{ }^{\circ} \mathrm{C}$ for $60 \mathrm{~s}$. Pre-miR-17 was folded in $5 \mathrm{mM} \mathrm{NaH}_{2} \mathrm{PO}_{4}$ at $60{ }^{\circ} \mathrm{C}$ for $5 \mathrm{~min}$ and then cooled down slowly to room temperature on the benchtop. Different concentrations $(10,20,50,100$, 200,500 or $1000 \mathrm{nM}$ ) of $\mathbf{5}$ were preincubated with $\mathrm{Fe}^{2+}$ and added to the folded RNA. After the first addition, a second and third aliquot of $\mathrm{Fe}^{2+}$ was added at 30 and 60 min of incubation respectively at $37^{\circ} \mathrm{C}$. The mixture was then incubated at $37^{\circ} \mathrm{C}$ for $24 \mathrm{~h}$ and the final cleavage products were separated on a $15 \%$ denaturing polyacrylamide gel and imaged using a Bio-Rad PMI phosphorimager.

In vitro Bleomycin cleavage of DNA plasmid. Compound $\mathbf{5 , 6}$ or bleomycin A5 $(0,10,100$, 500 or $1000 \mathrm{nM})$ were pre-activated with 1 eq of $\left(\mathrm{NH}_{4}\right)_{2} \mathrm{Fe}\left(\mathrm{SO}_{4}\right)_{2} \bullet 6 \mathrm{H}_{2} \mathrm{O}$ and then $500 \mathrm{ng}$ of a plasmid was added to a final volume of $20 \mu \mathrm{L}$. Another equivalent of $\left(\mathrm{NH}_{4}\right)_{2} \mathrm{Fe}\left(\mathrm{SO}_{4}\right)_{2} \bullet 6 \mathrm{H}_{2} \mathrm{O}$ was added after 30 min and 60 min respectively. The mixture was loaded on $1 \%$ agarose with $6 \times$ loading dye and stained with ethidium bromide. Bands were quantified using ImageJ image analysis software. 
Overexpression of the miR-17-92a-1 cluster. DU145 or MDA-MB-231 cells were grown to $80 \%$ confluency in a $100 \mathrm{~mm}$ dish followed by transfection with $2000 \mathrm{ng}$ of a pcDNA-miR-17-92a-1 or empty pcDNA vector as described previously. ${ }^{7}$ After transfection, cells were seeded into 6-well or 12-well plates and allowed to adhere for $12 \mathrm{~h}$ before being treated with $\mathbf{2}$ or $\mathbf{5}$ for $24 \mathrm{~h}$ for analysis of RNA expression. Total RNA was extracted and analyzed as described above.

Lentiviral transduction of MDA-MB-231 or DU145 cells with shRNAs. DU145 or MDA-MB231 cells were transduced to express shRNAs targeting STK4 or ZBTB4 respectively. The lentiviral particles were generated by co-transfection of HEK 293T cells with (i) anti- STK4 (NM_020899.3 - Genecopoeia) or anti-ZBTB4 (NM_006282.4 - Genecopoeia); (ii) packaging plasmid (psPAX2-Addgene); and (iii) envelop plasmid (pmD2.G -Addgene) using Lipofectamine 3000 according to the manufacturers protocol in a ratio of (1.0: $0.55: 1.3$ pmol). After removal of transfection media, media supernatants were harvested at 12, 24, and $48 \mathrm{~h}$. Virus particles were concentrated using the Lenti-X Concentrator (Takara Biosciences) according to the manufacturers protocol. The viral pellet was resuspended in $1 \mathrm{~mL}$ of $1 \times$ DPBS and $300 \mu \mathrm{L}$ was added to DU145 or MDA-MB-231 cells ( $50 \%$ confluency), which were allowed to grow for $48 \mathrm{~h}$. Cells were split twice and then sorted using a BD-FACS Aria Fusion ${ }^{\mathrm{TM}}$ cell sorter to isolate mCherry positive cells. These cells were then grown for RT-qPCR, Western, and Caspase 3/7 analysis of shRNA expression's effect on compound efficacy and phenotype.

Chem-CLIP/Competitive-Chem-CLIP. DU145 cells were grown in $100 \mathrm{~mm}$ dishes to $~ 80 \%$ confluency in complete growth medium. They were then treated with 3 or 4 for $6 \mathrm{~h}$ at $37^{\circ} \mathrm{C}$ followed by washing once with 1× DPBS and then irradiated with $365 \mathrm{~nm}$ light for $10 \mathrm{~min}$ in ice fold DPBS. Cells were then scraped from the dish, pelleted, and the supernatants removed. Total RNA was extracted using the miRNeasy Mini kit (Qiagen) with DNase treatment according to the

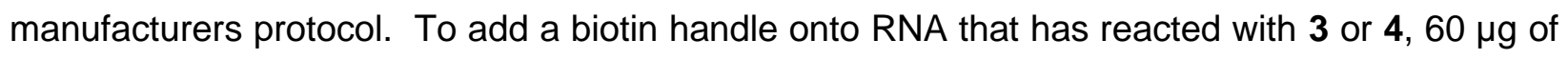
total RNA was treated with $200 \mu \mathrm{L}$ of Disulfide Azide Agarose beads (Click Chemistry Tools - 
1238-2) washed with $1 \times$ HEPES buffer $(25 \mathrm{mM}, \mathrm{pH} 7)$ and $30 \mu \mathrm{L}$ of $(1: 1: 1)$ of $250 \mathrm{mM}$ sodium ascorbate, $10 \mathrm{mM} \mathrm{CuSO}_{4}, 50 \mathrm{mM}$ THPTA added in that order to a $500 \mu \mathrm{L}$ final volume in $1 \times$ HEPES buffer. Tubes were incubated at $37^{\circ} \mathrm{C}$ for $2 \mathrm{~h}$ followed by centrifugation. The beads were then washed six times with $1 \times$ Wash Buffer $(10 \mathrm{mM}$ Tris- $\mathrm{HCl}, \mathrm{pH}$ 7.0, $4 \mathrm{M} \mathrm{NaCl}, 1 \mathrm{mM}$ EDTA, and $0.2 \%(\mathrm{v} / \mathrm{v})$ Tween-20) followed by two washes with nano pure water. Bound RNA was cleaved by treating the beads with $200 \mu \mathrm{L}$ of $1: 1$ TCEP $(200 \mathrm{mM})$ pre-reduced with $\mathrm{K}_{2} \mathrm{CO}_{3}(600$ $\mathrm{mM}$ ) for $30 \mathrm{~min}$ at $37^{\circ} \mathrm{C}$ followed by quenching with 1 volume of iodoacetamide (400 mM) for 30 min at room temperature. The supernatants were removed, and the beads washed once with Nano pure water and combined with the supernatants, which were then concentrated by vacuum to $100 \mu \mathrm{L}$ and the RNA cleaned up using RNA clean XP beads per the manufacturer's protocol. This RNA was then subjected to RT-qPCR analysis to measure enrichment of pri-miR-17-92 and pre-miR-17, which was calculated as the ratio of levels after pulldown to before pulldown described previously. ${ }^{8}$

Proteomics analysis of DU145 cells treated with 5. DU145 cells were grown in $100 \mathrm{~mm}$ dishes in growth medium and treated with 5 at $500 \mathrm{nM}$ or vehicle (DMSO) for $24 \mathrm{~h}$. After the treatment period, the cells were scraped from the dish and pelleted. The cells were re-suspended in $1 \times$ DPBS and pelleted; this step was repeated. The cells were lysed in $1 \times$ DPBS by sonication using Digital Sonifier SFX 150 (Branson). Protein concentration in lysates was measured using the Bradford assay (BioRad). An equal amount of protein from each sample (30 $\mu \mathrm{g})$ was then denatured in $6 \mathrm{M}$ urea in $50 \mathrm{mM} \mathrm{NH} \mathrm{NHCO}_{3}(\mathrm{pH}$ 8), reduced with $10 \mathrm{mM}$ tris(2carboxyethyl)phosphine hydrochloride (TCEP) for $30 \mathrm{~min}$, and alkylated with $25 \mathrm{mM}$ iodoacetamide for $30 \mathrm{~min}$; the alkylation step was completed in the dark. Samples were diluted to $2 \mathrm{M}$ urea with $50 \mathrm{mM} \mathrm{NH}_{4} \mathrm{HCO}_{3}$, and digested with trypsin (Thermo Scientific, $1.5 \mu \mathrm{L}$ of 0.5 $\mu \mathrm{g} / \mu \mathrm{L}$ ) in the presence of $1 \mathrm{mM} \mathrm{CaCl}$ for $12 \mathrm{~h}$ at $37^{\circ} \mathrm{C}$. Samples were acidified with acetic acid to a final concentration of $5 \%(\mathrm{v} / \mathrm{v})$, desalted over a self-packed $\mathrm{C} 18$ spin column, and dried using 
micro IR vacuum concentrator (CentriVap). Samples were analyzed by LC-MS/MS (see below), and the MS data were processed with MaxQuant (see below).

LC-MS/MS Analysis. Peptides were resuspended in water with $0.1 \%(\mathrm{v} / \mathrm{v})$ formic acid (FA) and analyzed using EASY-nLC 1200 nano-UHPLC coupled to Q Exactive HF-X QuadrupoleOrbitrap mass spectrometer (Thermo Scientific). The chromatography column consisted of a 50 $\mathrm{cm}$ long, $75 \mu \mathrm{m}$ i.d. microcapillary capped by a $5 \mu \mathrm{m}$ tip and packed with ReproSil-Pur 120 C18AQ $2.4 \mu \mathrm{m}$ beads (Dr. Maisch $\mathrm{GmbH}$ ). LC solvents were $0.1 \%$ FA in $\mathrm{H}_{2} \mathrm{O}$ (Buffer A) and $0.1 \%$ FA in $90 \% \mathrm{MeCN}: 10 \% \mathrm{H}_{2} \mathrm{O}$ (Buffer B). Peptides were eluted into the mass spectrometer at a flow rate of $300 \mathrm{~nL} / \mathrm{min}$ over a $240 \mathrm{~min}$ linear gradient $\left(5-35 \%\right.$ Buffer B) at $65^{\circ} \mathrm{C}$. Data were acquired in data-dependent mode (top-20, NCE $28, R=7500$ ) after full MS scan $(R=60000, \mathrm{~m} / \mathrm{z}$ 400-1300). Dynamic exclusion was set to $10 \mathrm{~s}$, peptide match set to prefer, and isotope exclusion was enabled.

MaxQuant Analysis. The mass spectrometer data were analyzed with MaxQuant ${ }^{9}$ (V1.6.1.0) and searched against the human proteome (Uniprot) and a common list of contaminants (included in MaxQuant). The first peptide search tolerance was set at 20 ppm; 10 ppm was used for the main peptide search, and fragment mass tolerance was set to $0.02 \mathrm{Da}$. The false discovery rate for peptides, proteins, and sites identification was set to $1 \%$. The minimum peptide length was set to six amino acids, and peptide re-quantification, label-free quantification (MaxLFQ), and "match between runs" were enabled. The minimal number of peptides per protein was set to 2. Methionine oxidation was searched as a variable modification, and carbamidomethylation of cysteines was searched as a fixed modification.

PD-L1 Overexpression Analysis. DU145 cells were seeded into $60 \mathrm{~mm}$ dishes and grown to a $\sim 70 \%$ confluency. Then, they were transfected with $200,1000,2000$, or $4000 \mathrm{ng}$ of the pGIPZPD-L1-EGFP plasmid to overexpress PD-L1 for $24 \mathrm{~h}$. Total RNA was extracted to assess the change in mRNA levels required to alter surface PD-L1 expression. Cell surface expression was 
measured by scraping transfected cells from the $60 \mathrm{~mm}$ dish and then washing them once with $1 \times$ DPBS. They were then resuspended in Buffer 1 ( $1 \times$ DPBS containing $5 \%(v / v)$ FBS and $1 \%$ $\left.(\mathrm{w} / \mathrm{v}) \mathrm{NaN}_{3}\right) \quad$ Next, 1 volume of $1 \times$ DPBS with $5 \%$ BSA was added, and the cells were incubated for 15 min followed by addition of anti-PD-L1-Alexa 647 conjugate (Cell Signaling-417265; final dilution of 1:50). The cells were incubated at room temperature in the dark with the antibody for $1.5 \mathrm{~h}$ followed by three washes with $1 \times$ DPBS before resuspension in Buffer 1 for Fluorescence Assisted Cell Sorting (FACS) analysis. Cells were analyzed on a BD-FACS LSRII using standard laser parameters for Alexa-647 expression. FACS data and plots were analyzed on FlowJo 6, and the mean at maximum intensity was used for plotting the data.

Cellular uptake analysis. DU145 and MDA-MB-231 cells were seeded into a 96-well white clear bottom plate at 10,000 cells/well and allowed to adhere overnight. Once adhered, the cells were grown to $\sim 50 \%$ confluency and then treated with 2,5 , or 7 at $5 \mu \mathrm{M}$ for $24 \mathrm{~h}$ while also leaving untreated wells for generation of a standard curve. This concentration was chosen to allow for adequate signal above noise. After $24 \mathrm{~h}$, cells were lysed in $100 \mu \mathrm{L}$ of RNA lysis buffer (Zymo Research) for $5 \mathrm{~min}$. Compound 2, 5, or 7 were spiked into untreated samples at 100, 10, 1, 0.1, and $0.01 \mathrm{nM}$ to create a standard curve of compound fluorescence. Using a Biotek FLX-800 fluorescence plate reader (excitation: 360/340; emission 460/440; sensitivity $=90$ ) the fluorescence of $\mathbf{2 , 5}$, and $\mathbf{7}$ was measured. Concentrations were determined by extrapolating from the standard curves mentioned above.

Cellular localization of 2, 5, and 7 in DU145 and MDA-MB-231 cells. DU145 and MDA-MB231 cells were seeded into a poly-D-lysine coated glass bottom $35 \mathrm{~mm}$ dishes (MatTek). Cells were then treated with $\mathbf{2 , 5}$, or $\mathbf{7}(5 \mu \mathrm{M})$ for $24 \mathrm{~h}$. After incubation, cells were washed with PBS twice and the nucleus stained with Syto 82 for 20 min in 1x indicator free RPMI 1640 (Gibco) . Images were taken on an Olympus FluoView 1000 confocal microscope at 100X magnification in 1x indicator free RPMI 1640 and images were overlayed in the Olympus FluoView software to 
determine co-localization of compounds with cellular compartments. Brightness and Contrast were adjusted to settings of 84 and -49 , respectively, in Adobe Photoshop for all images.

Absolute quantification of pri-, pre-, and mature miRNAs. Transcripts of pre-miR-17, premiR-18a, and the corresponding $5 p$ mature sequences were transcribed in vitro and purified as described above. Precursor miRNAs ( $1 \times 10^{14}$ copies) were reverse transcribed using QScript RT (Quanta bio) in a total volume of $40 \mu \mathrm{L}$. Mature miRNAs ( $1 \times 10^{14}$ copies) were reverse transcribed using the miScript II RT Kit (Qiagen) in a total volume of $40 \mu \mathrm{L}$ reaction. Serial dilutions of the RT reactions (1:10) were used to create a standard curve of copy number versus $C_{t}$ which was used to calculate copy numbers of each transcript in DU-145 and MDA-MB-231 cells. 


\section{Synthetic Methods and Characterization}

\section{Abbreviations:}

DCM: Dichloromethane

DIC: N,N'-Diisopropylcarbodiimide

DIEA: Diisopropyl ethyl amine

DMF: Dimethylformamide

DMSO: Dimethyl sulfoxide

EDTA: Ethylenediaminetetraacetic acid

HATU: Hexafluorophosphate azabenzotriazole tetremethyl uronium

HOAt: 1-hydroxy-7-azabenzotriazole

HPLC: High-performance Liquid Chromatography

$\mathrm{MeOH}$ : Methanol

TFA: Trifluoro Acetic Acid
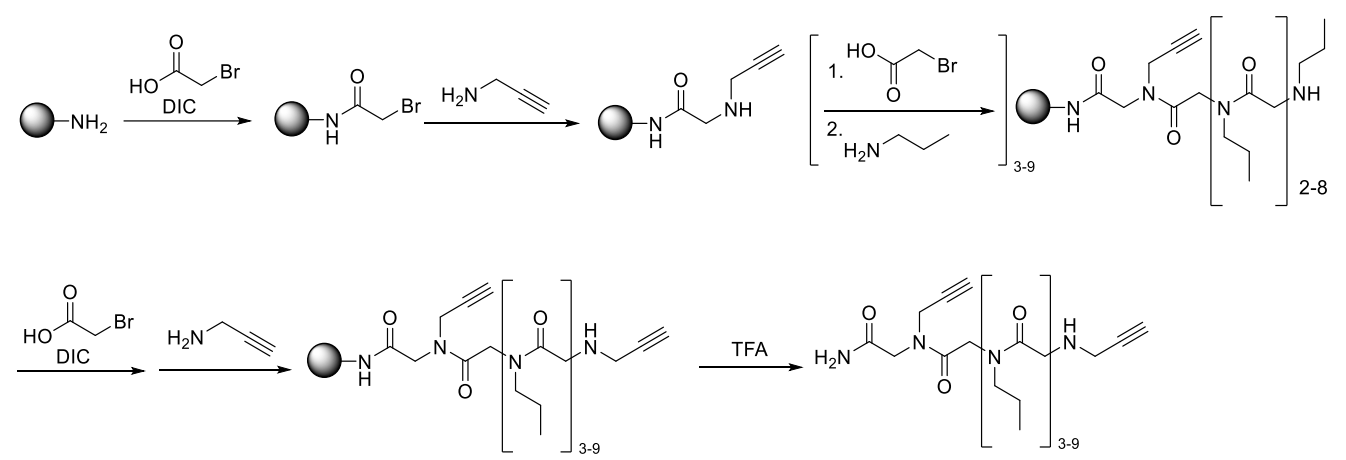

General Protocol for Peptoid Synthesis: Peptoids were synthesized via standard resinsupported oligomerization protocol. Rink resin $(555 \mathrm{mg}, 0.6 \mathrm{mmol}$ ) was activated with $20 \%$ piperidine in DMF for 30 min. After that, solvent was removed and washed with DMF and DCM for 3 times respectively.

Coupling Step: To the resin was added $3 \mathrm{~mL}$ of $1 \mathrm{M}$ bromoacetic acid in DCM ( $3 \mathrm{mmol}, 5 \mathrm{eq})$ and DIC $(3.0 \mathrm{mmol}, 519 \mu \mathrm{L})$. The resin was shaken at room temperature for $2 \mathrm{~h}$. Then the solvent was removed, and the resin was washed with DMF for three times. 
Displacement step: To the resin was added $5 \mathrm{~mL}$ DMF and propargylamine. The resin was shaken at room temperature for $2 \mathrm{~h}$. Then the solvent was removed, and the resin was washed with DMF for three times.

Peptoid Chain Extension: a) To the resin was added $5 \mathrm{~mL}$ DMF, bromoacetic acid and DIC. The resin was shaken at room temperature for $2 \mathrm{~h}$. Then the solvent was removed, and the resin was washed with DMF for three times. b) To the resin was added $5 \mathrm{~mL}$ DMF and propyl amine. The resin was shaken at room temperature for $2 \mathrm{~h}$. Then the solvent was removed, and the resin was washed with DMF for three times. Steps a) and b) were repeated for another 2-9 times.

Cleavage of the peptoid: The resin was treated with $30 \%$ TFA in DCM and shaken at room temperature for $30 \mathrm{~min}$. The solution was collected and concentrated in vacuo. The residue was purified by HPLC.
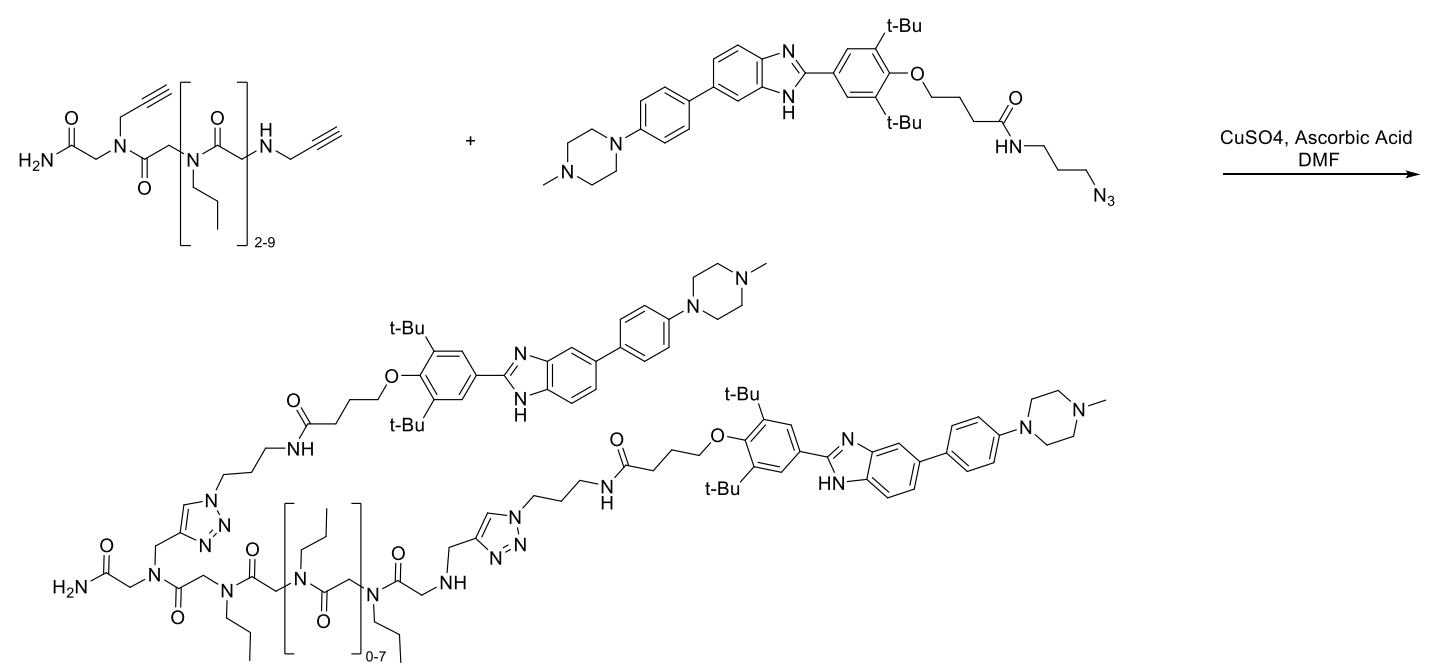

General procedure for the click chemistry: A solution of the peptoid (1 eq), Monomer (2 eq), $\mathrm{CuSO}_{4} \bullet 5 \mathrm{H}_{2} \mathrm{O}(2 \mathrm{eq})$ and ascorbic acid (2 eq) in DMF was stirred at room temperature overnight. The resulting mixture was purified by HPLC to afford the corresponding dimer. 

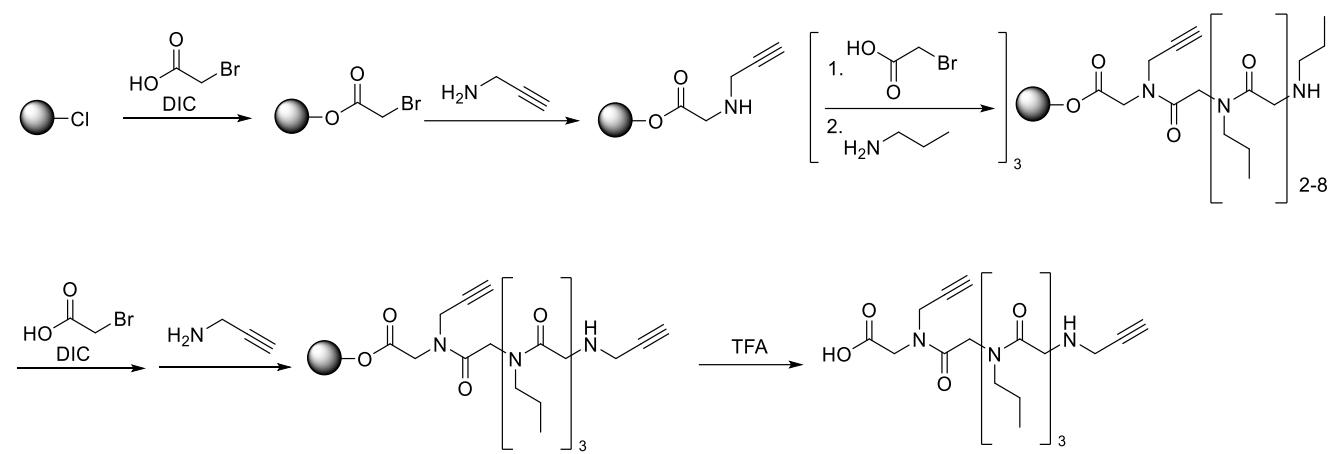

General Protocol for Peptoid Synthesis: Peptoids were synthesized via standard resinsupported oligomerization protocol. Chloro trityl resin (555 mg, $0.6 \mathrm{mmol}$ ) was activated with $1 \mathrm{M}$ $\mathrm{HCl} /$ dioxane in DCM (4 M HCl dioxane was diluted with DCM) for $30 \mathrm{~min}$. After that, solvent was removed and washed with DMF and DCM for 3 times respectively.

Coupling Step: To the resin was added $3 \mathrm{~mL}$ of $1 \mathrm{M}$ bromoacetic acid in DCM (3 mmol, 5 eq) and DIC (3.0 mmol, $519 \mu \mathrm{L})$. The resin was shaken at room temperature for $2 \mathrm{~h}$. The solvent was removed, and the resin was washed with DMF for three times.

Displacement step: To the resin was added $5 \mathrm{~mL}$ DMF and propargylamine. The resin was shaken at room temperature for $2 \mathrm{~h}$. Then the solvent was removed, and the resin was washed with DMF for three times.

Peptoid Chain Extension: a) To the resin was added $5 \mathrm{~mL}$ DMF, bromoacetic acid and DIC. The resin was shaken at room temperature for $2 \mathrm{~h}$. Then the solvent was removed, and the resin was washed with DMF for three times. b) To the resin was added $5 \mathrm{~mL}$ DMF and propylamine. The resin was shaken at room temperature for $2 \mathrm{~h}$. Then the solvent was removed, and the resin was washed with DMF for three times. Steps a) and b) were repeated twice.

Cleavage of the peptoid: The resin was treated with $30 \%$ TFA in DCM and shaken at room temperature for $30 \mathrm{~min}$. The solution was collected and concentrated in vacuo. The residue was purified by HPLC.

\section{Synthesis of 5 and 6}



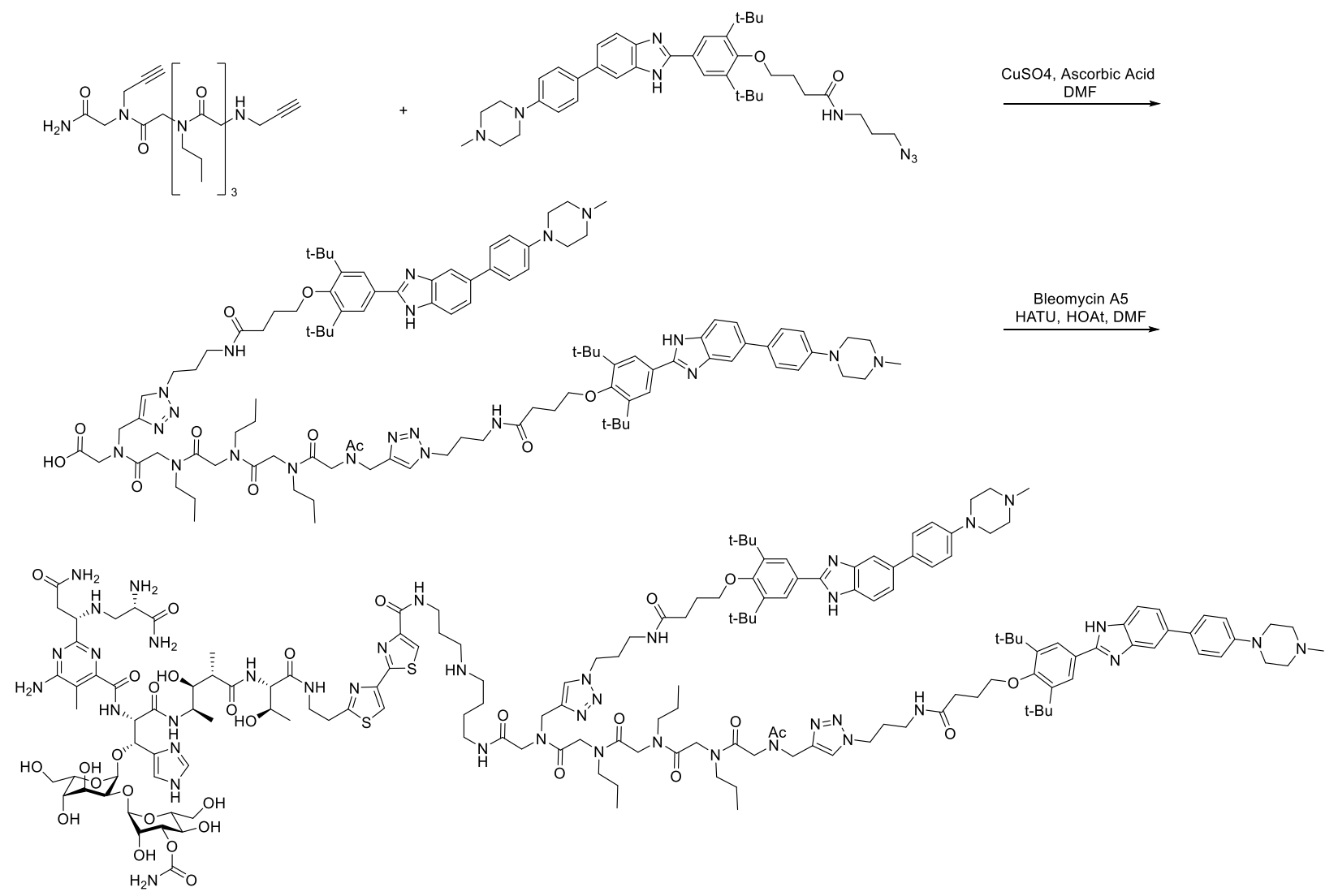

The Dimer acid was obtained by the general click reaction as described above. The acid was preincubated with HATU (1.5 equiv.), HOAt (1.5 equiv.) and DIEA (1.5 equiv.) in DMF for 10 min. Then a solution of Bleomycin A5 (3 equiv.) in DMSO was added. The mixture was stirred at room temperature for $2 \mathrm{~h}$ and then the mixture was subjected to HPLC purification. After injection of the sample, the column was washed with $50 \mathrm{mM}$ EDTA ( $\mathrm{pH}$ 6.7) for $15 \mathrm{~min}$ to remove copper ion and then water for another $15 \mathrm{~min}$ to remove EDTA. 5 was purified with a linear gradient from 0 to $100 \% \mathrm{~B}(\mathrm{MeOH}+0.1 \%$ TFA) in $\mathrm{A}$ (water $+0.1 \%$ TFA) over $60 \mathrm{~min}$ at a flow rate of $5 \mathrm{~mL} / \mathrm{min}$. MALDI: $[\mathrm{M}+\mathrm{H}]+$ calculated: $3297.7249,[\mathrm{M}+\mathrm{H}]+$ observed: $3298.9922 . S y n t h e s i s$ of 2-FAM 


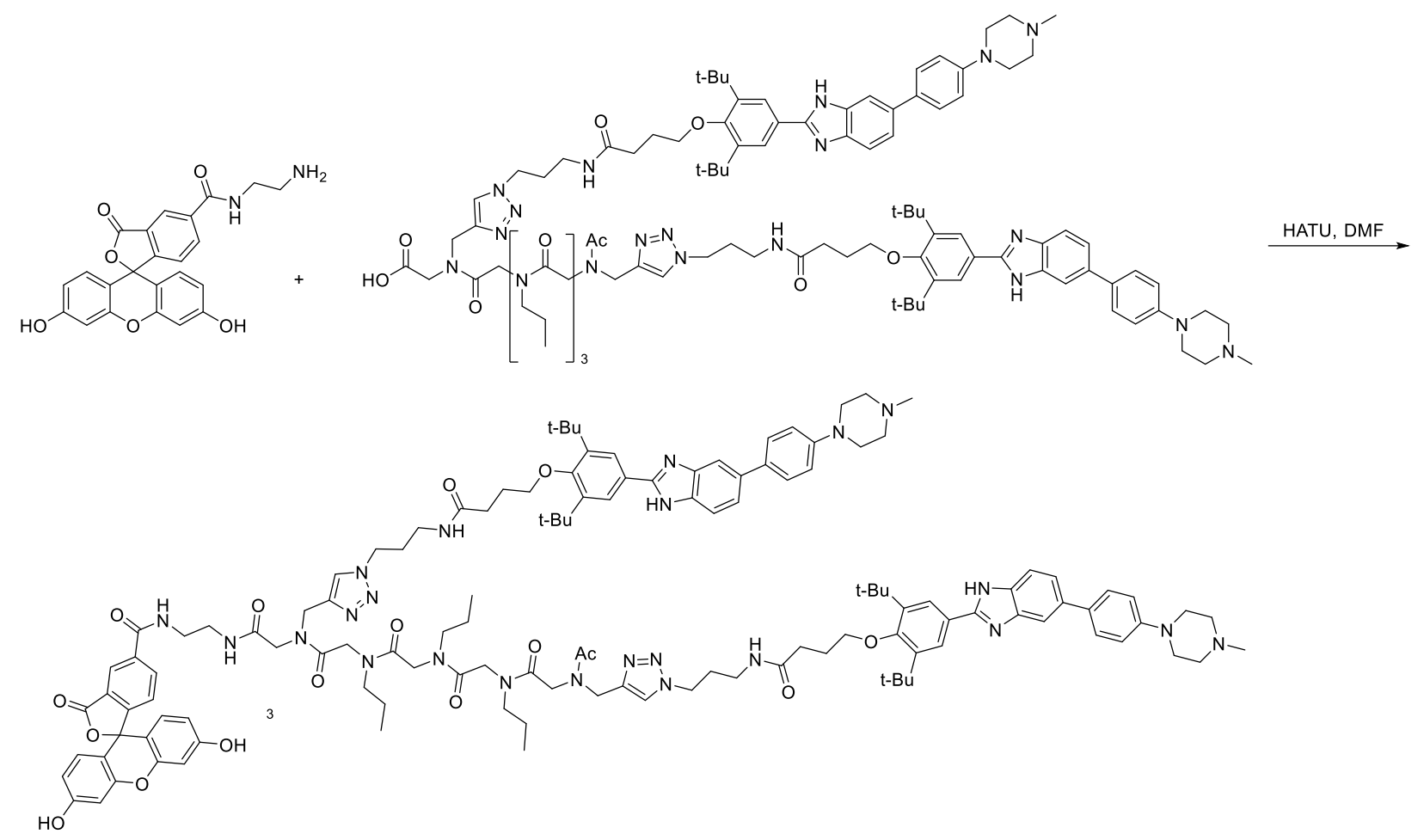

A solution of the Dimer acid was incubated with HATU (1.5 equiv.) at room temperature for 10 min and then the FAM amine was added followed by the addition of 5 equiv. of DIEA and the mixture was stirred at room temperature for another $2 \mathrm{~h}$. 2-FAM was purified by HPLC. MALDI: $[\mathrm{M}+\mathrm{K}]+$ calculated: $2316.9388,[\mathrm{M}+\mathrm{K}]^{+}$observed: 2317.3967. 


\section{Synthesis of 7}
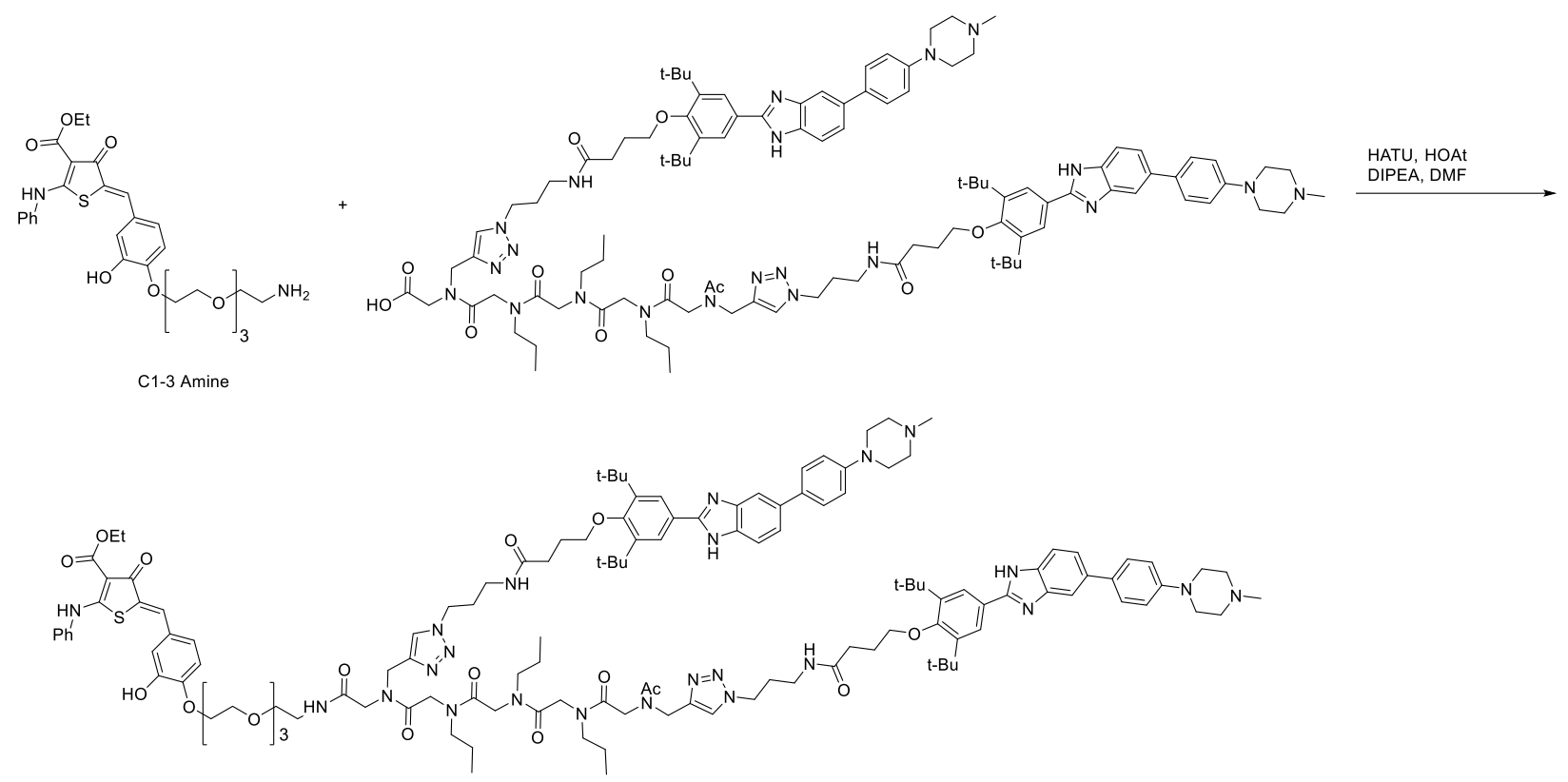

To a solution of the Dimer acid in DMSO $(12 \mathrm{mM}, 90 \mu \mathrm{L}, 1.08 \mu \mathrm{mol})$ was added a mixture of HATU (0.62 mg, $1.5 \mu \mathrm{mol})$ and HOAt $(0.22 \mathrm{mg}, 1.5 \mu \mathrm{mol})$ in DMF $(5 \mu \mathrm{L})$, and the solution was stirred for $10 \mathrm{~min}$ at room temperature. A mixture of $\mathbf{C 1 - 3}$ amine $(1.2 \mathrm{mg}, 2.02 \mu \mathrm{mol})$, synthesized as previously described, ${ }^{10}$ and DIPEA $(0.94 \mu \mathrm{L}, 5.4 \mu \mathrm{mol})$ in DMF $(12 \mu \mathrm{L})$ was added to the solution and stirred overnight. After dilution with $30 \% \mathrm{MeOH} / \mathrm{H}_{2} \mathrm{O}(0.1 \% \mathrm{TFA})$, the product was purified by HPLC $\left(70-90 \% \mathrm{MeOH} / \mathrm{H}_{2} \mathrm{O}\right.$ in $30 \mathrm{~min}, 0.1 \%$ TFA) to give 7 (0.3 mg, $\left.0.12 \mu \mathrm{mol}, 11 \%\right)$. HR-MS (ESI) calculated. for $\mathrm{C}_{133} \mathrm{H}_{176} \mathrm{~N}_{23} \mathrm{O}_{18} \mathrm{~S}^{-}[\mathrm{M}-\mathrm{H}]^{-}: 2415.3290$; observed: 2415.3236 . 

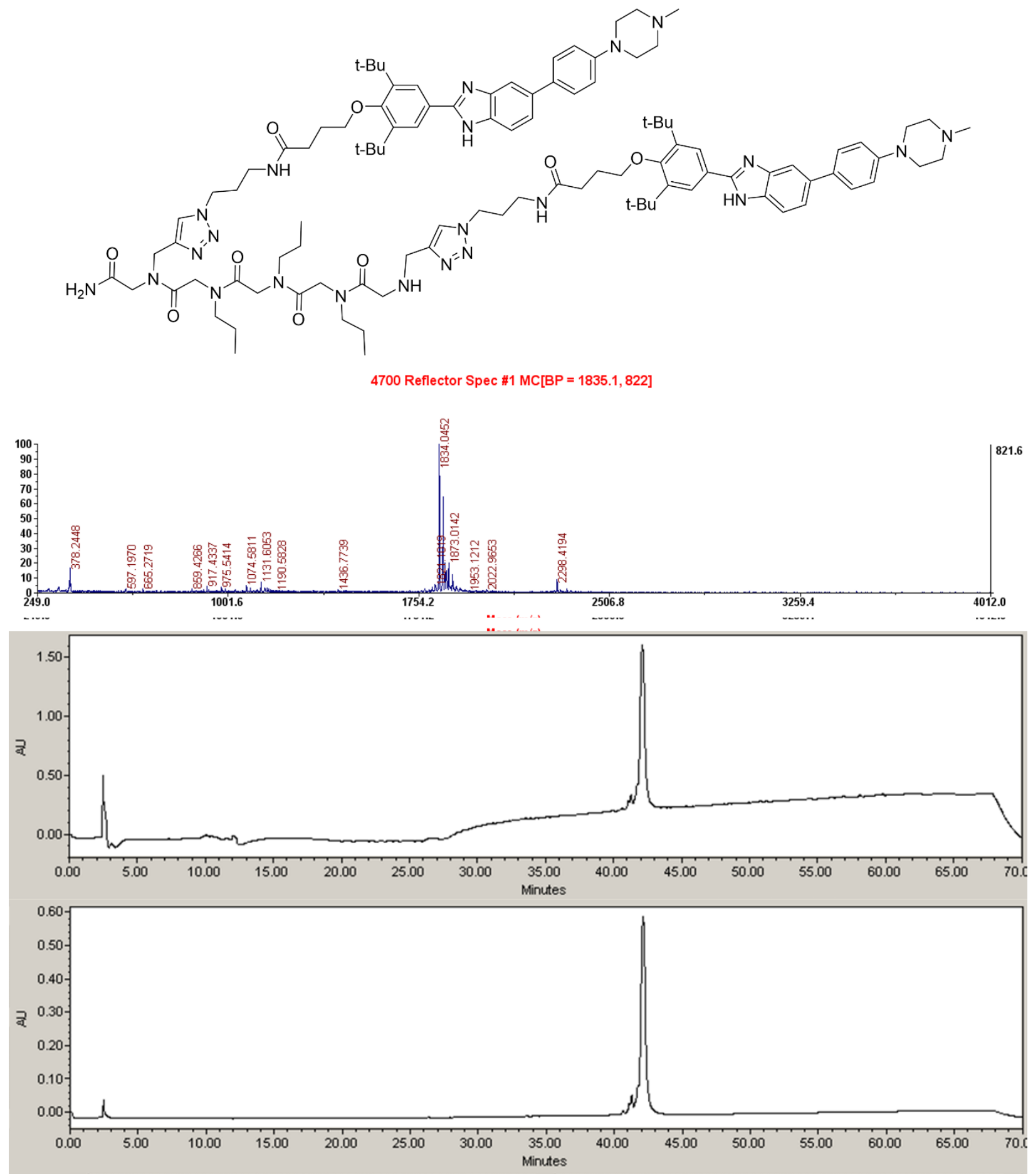

Figure S12: Characterization of Dimer $n=3$. 


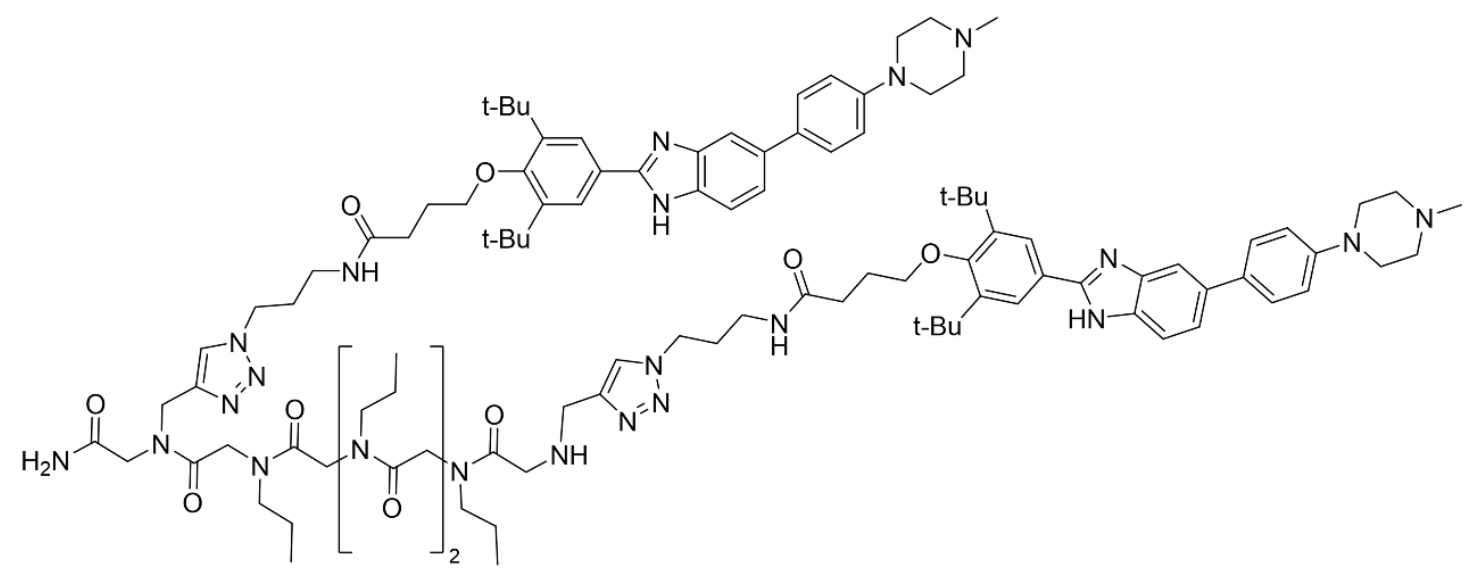

4700 Reflector Spec \#1 MC[BP = 1934.2, 1172]
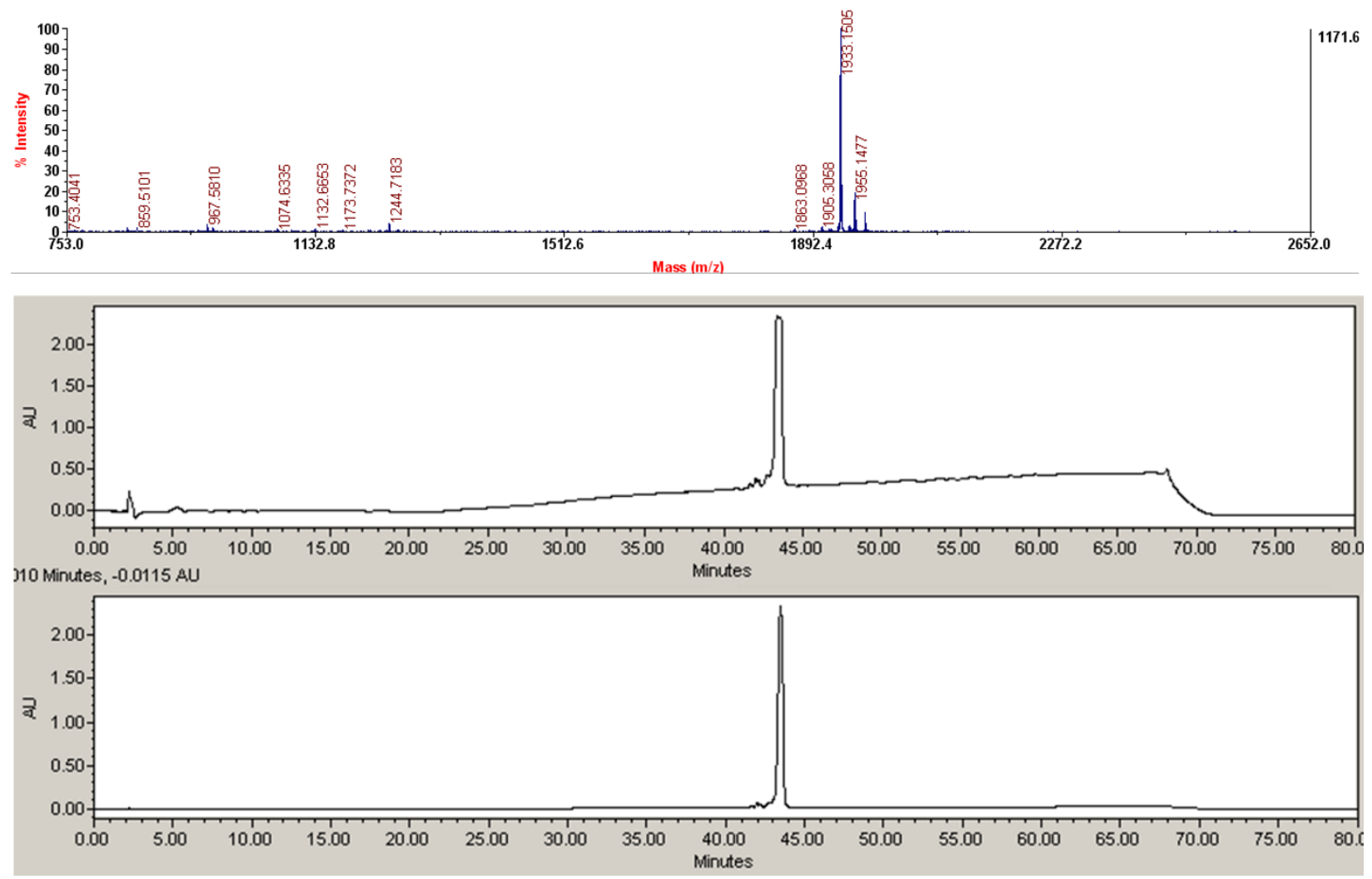

Figure S13: Characterization of Dimer $n=4$. 

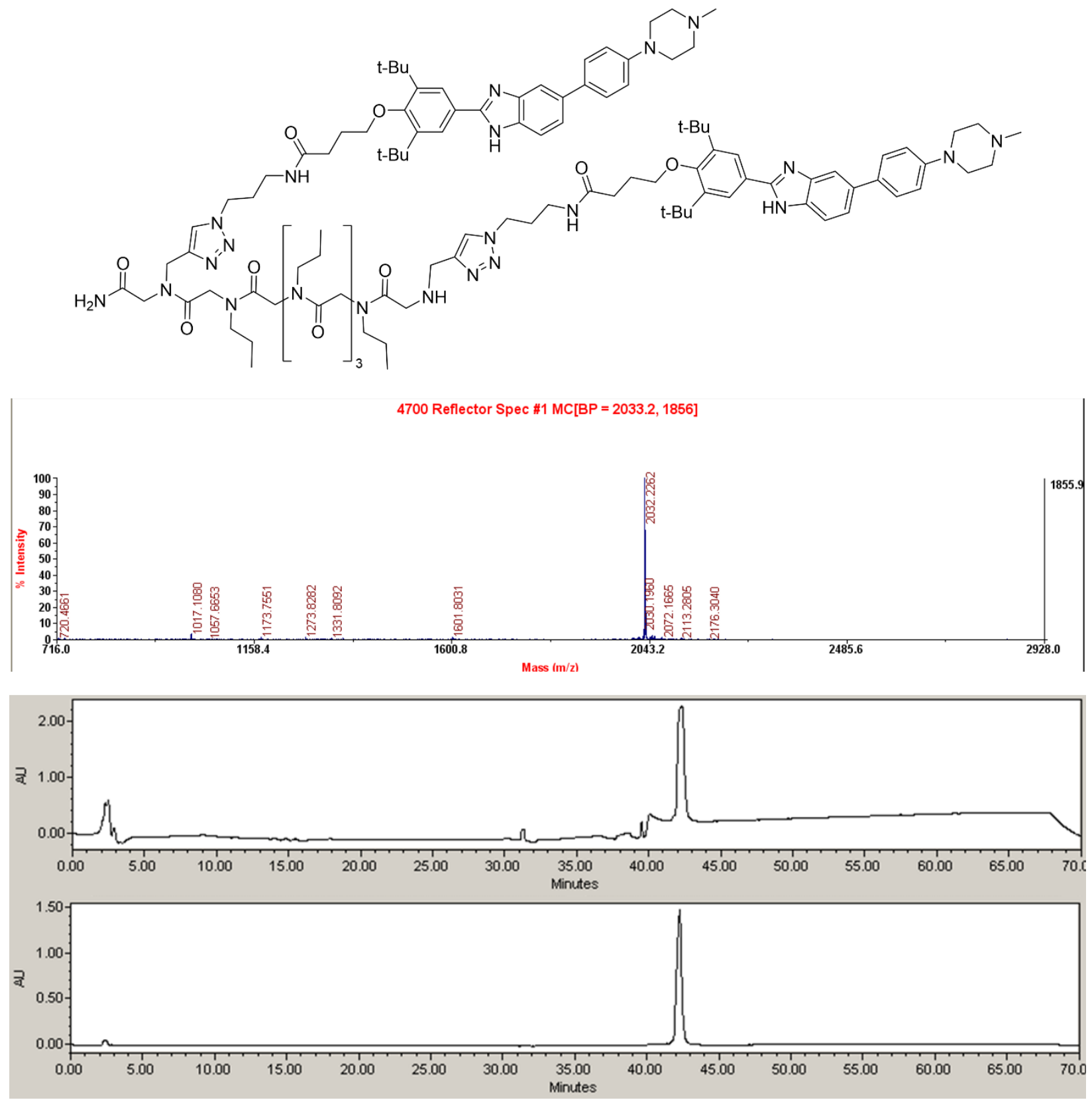

Figure S14: Characterization of Dimer $n=5$. 


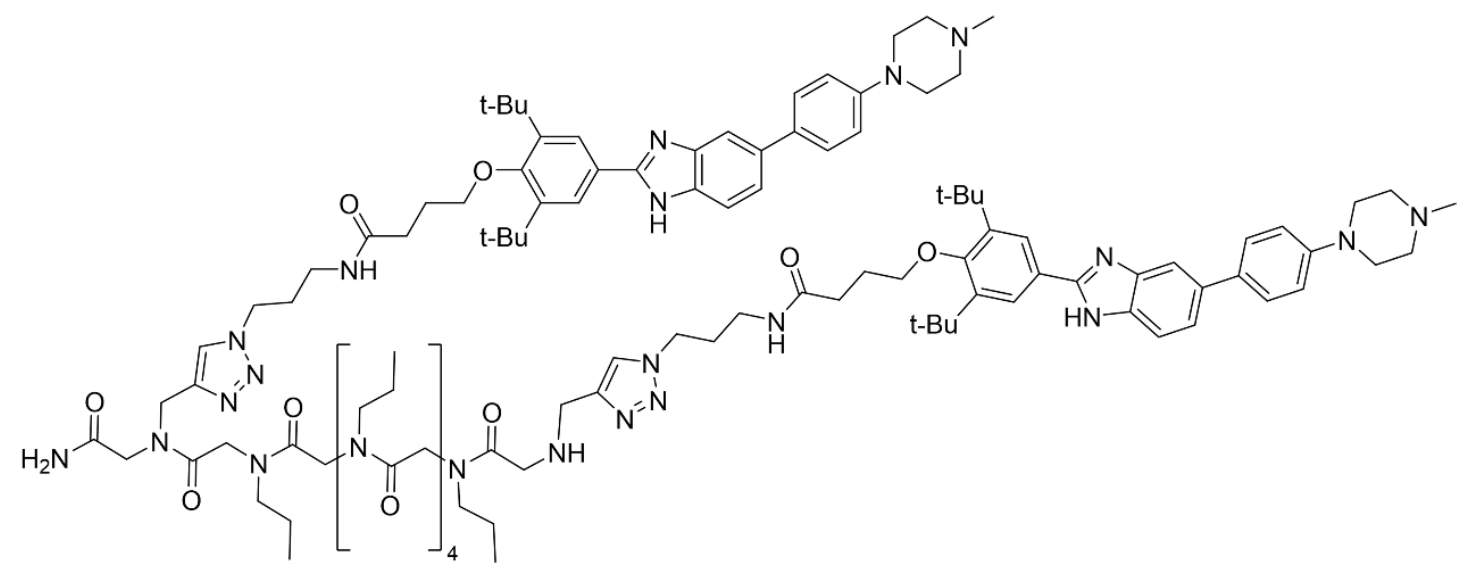

4700 Reflector Spec \#1 MC[BP = 2132.3, 1127]
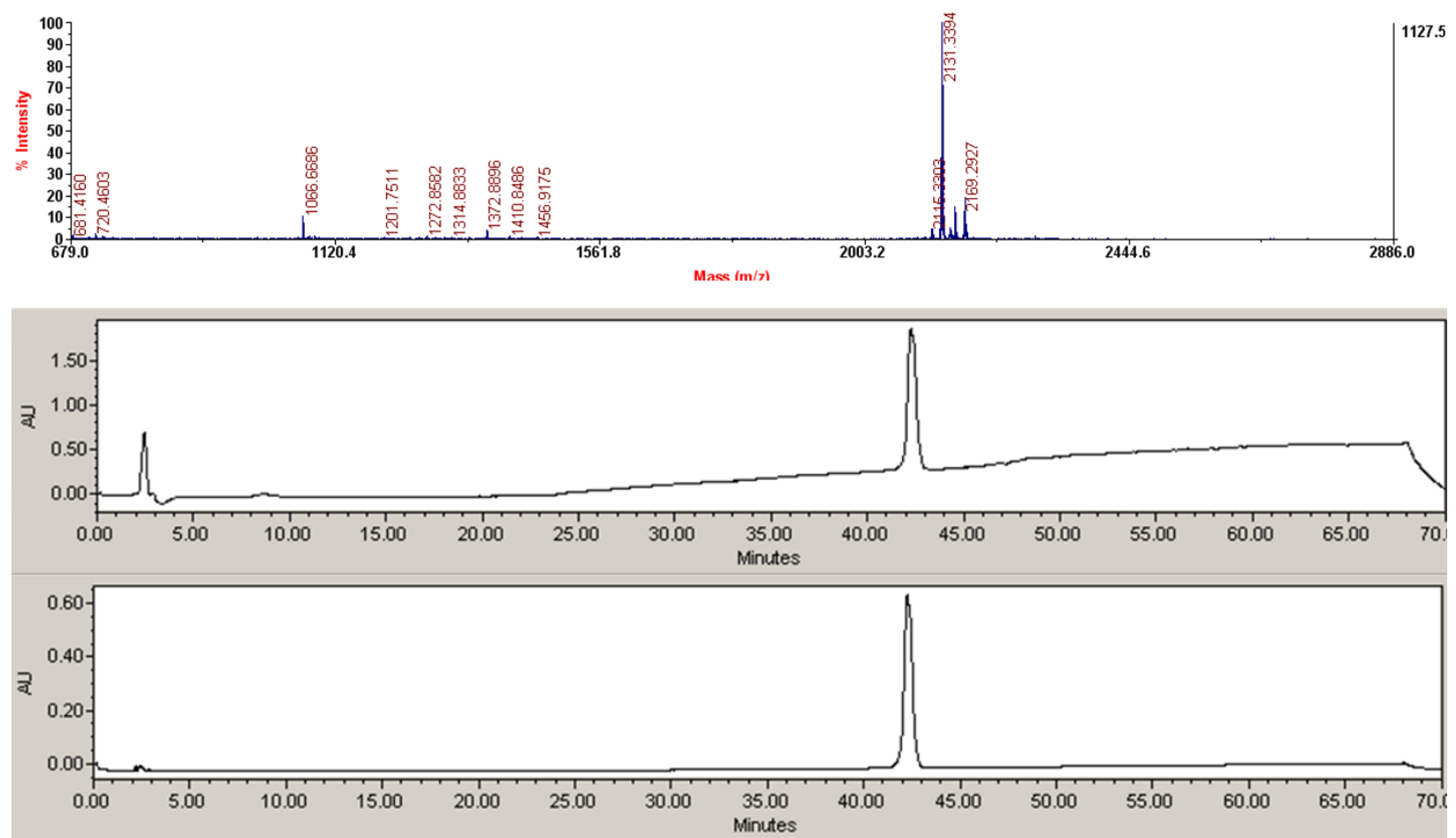

Figure S15: Characterization of Dimer $n=6$. 


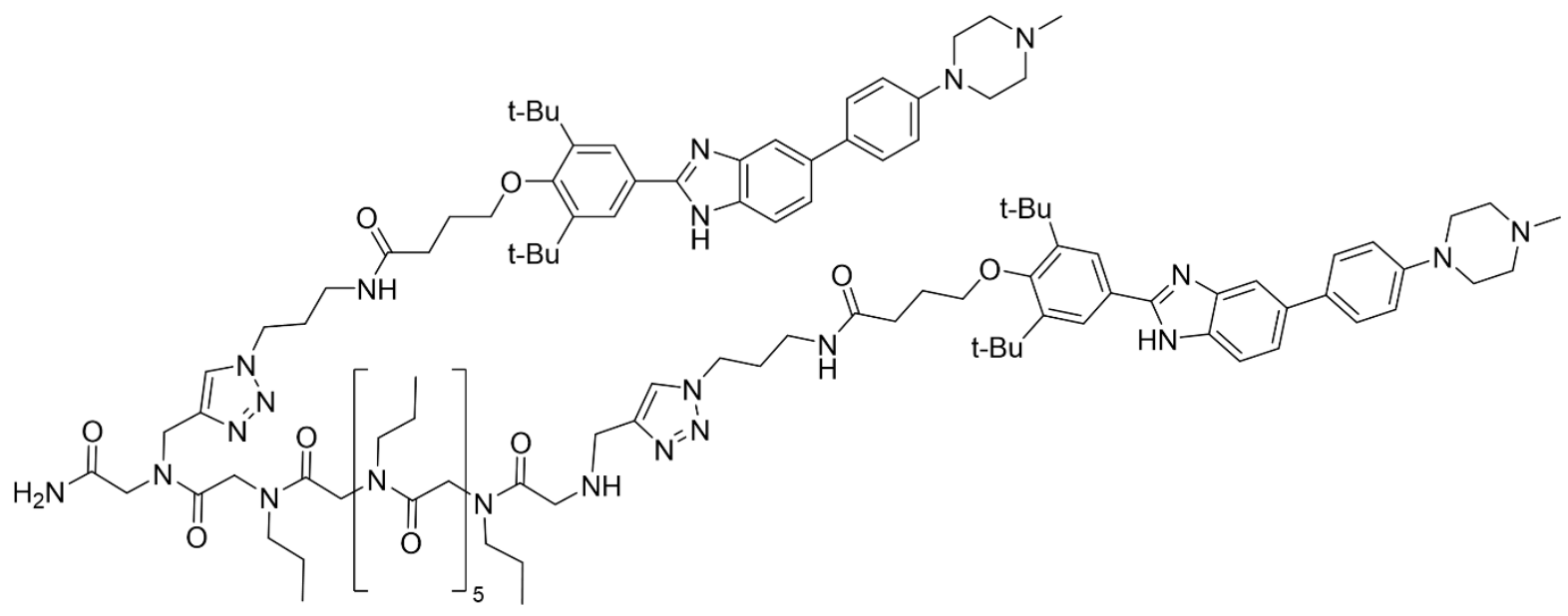

4700 Reflector Spec \#1 MC[BP = 2231.2, 1220]
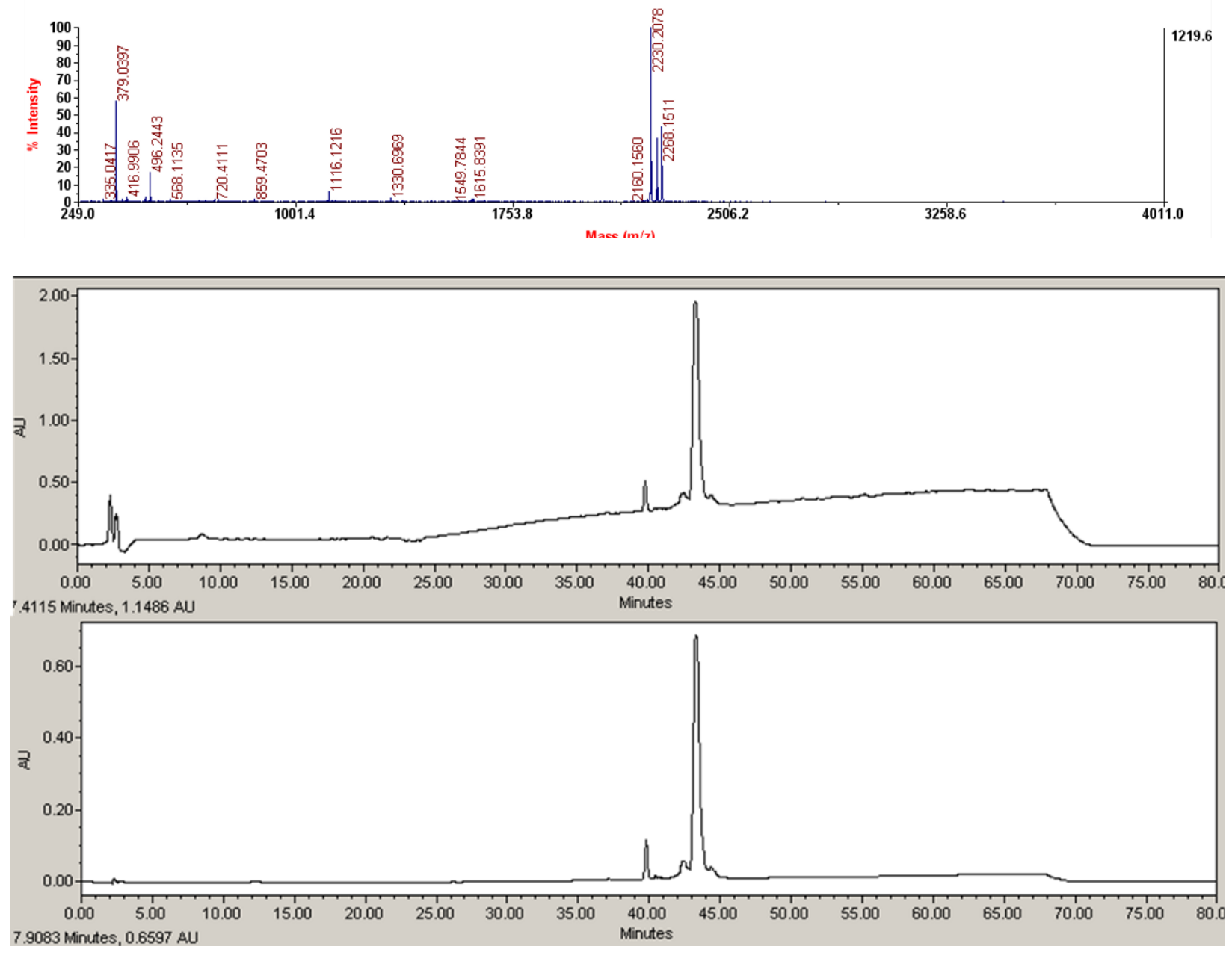

Figure S16: Characterization of Dimer $n=7$. 

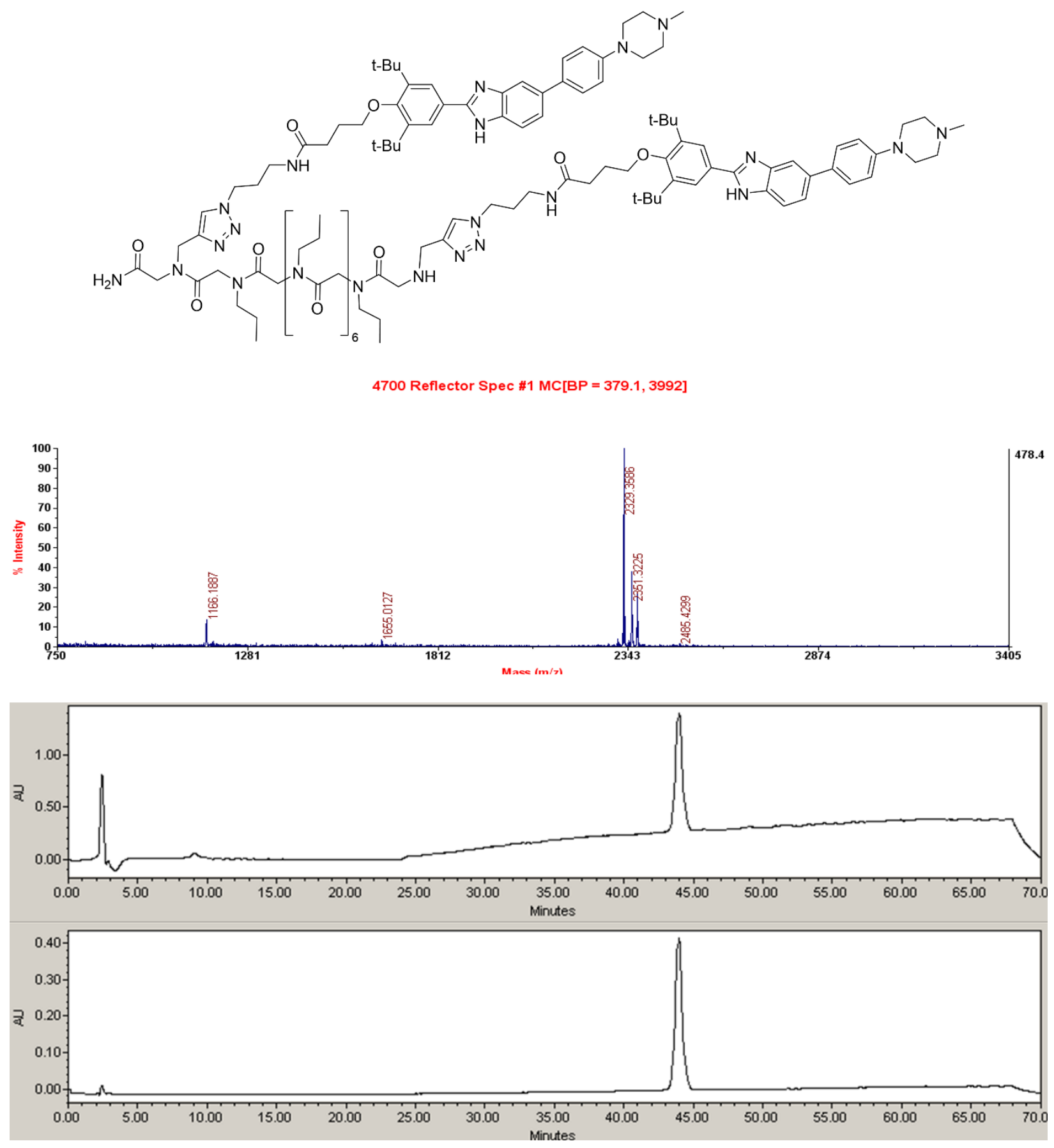

Figure S17: Characterization of Dimer $n=8$. 


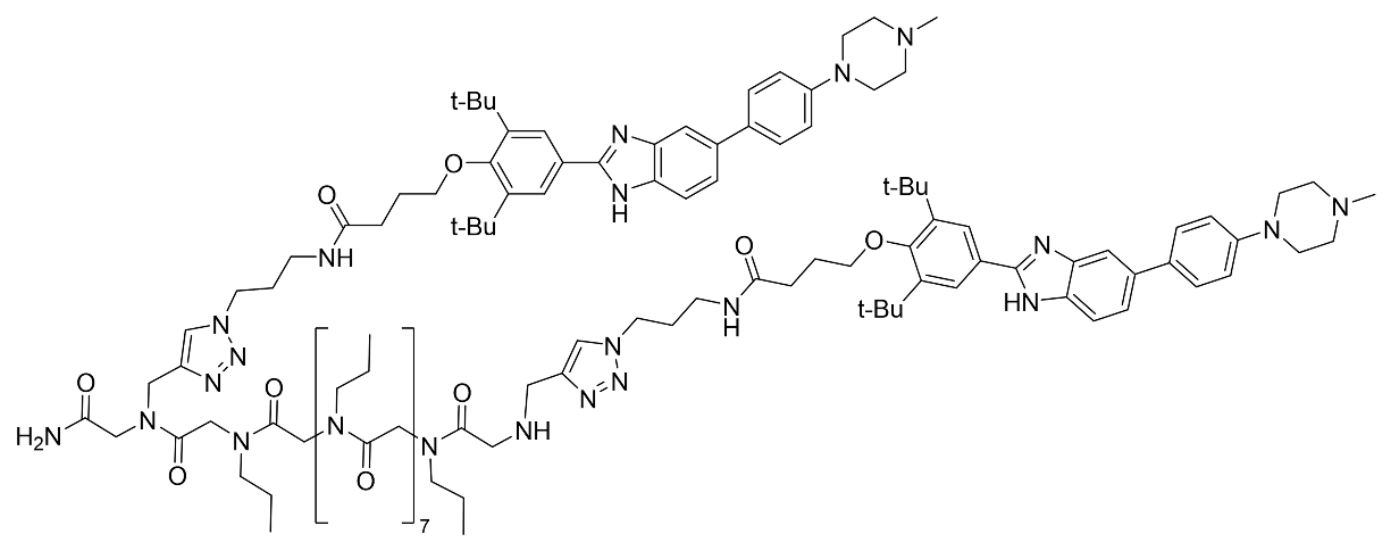

4700 Reflector Spec \#1 MC $[B P=\mathbf{2 4 2 9 . 4}, 1226]$
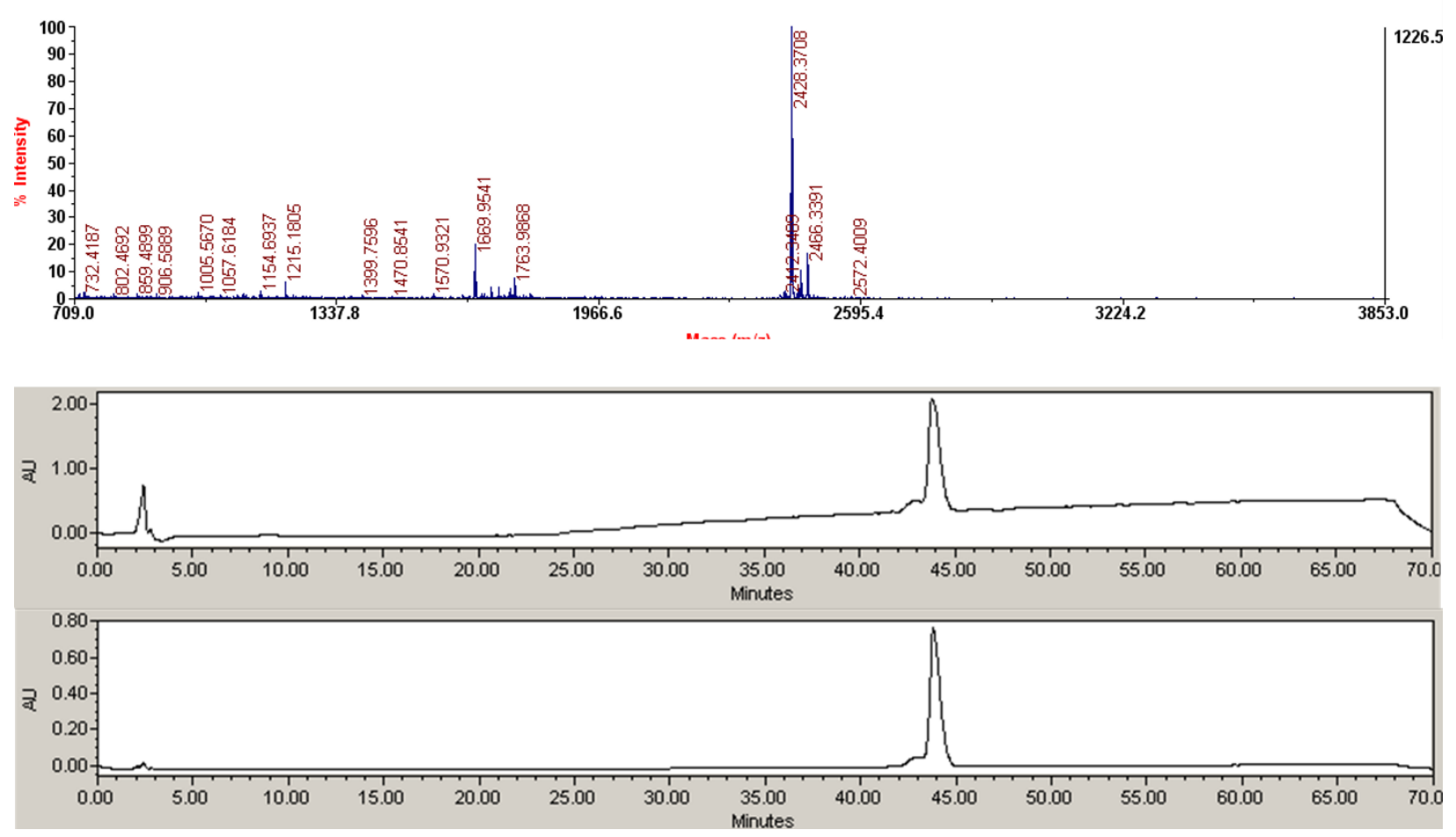

Figure S18: Characterization of Dimer $n=9$. 


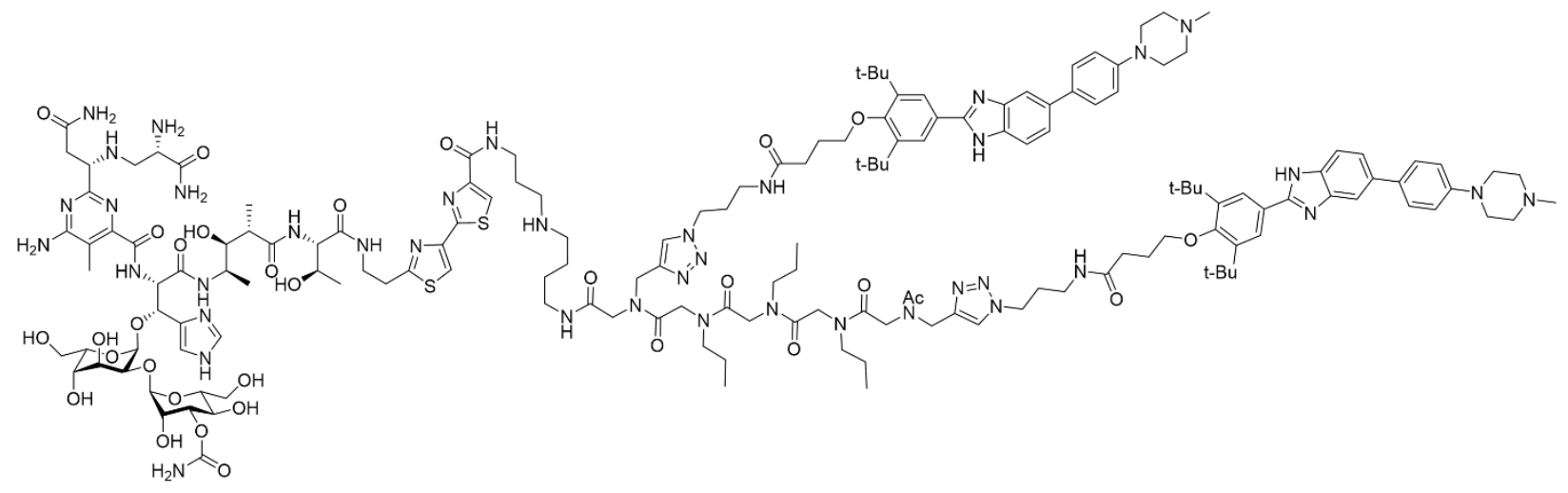

4700 Reflector Spec \#1 MC [BP = 379.1, 632]
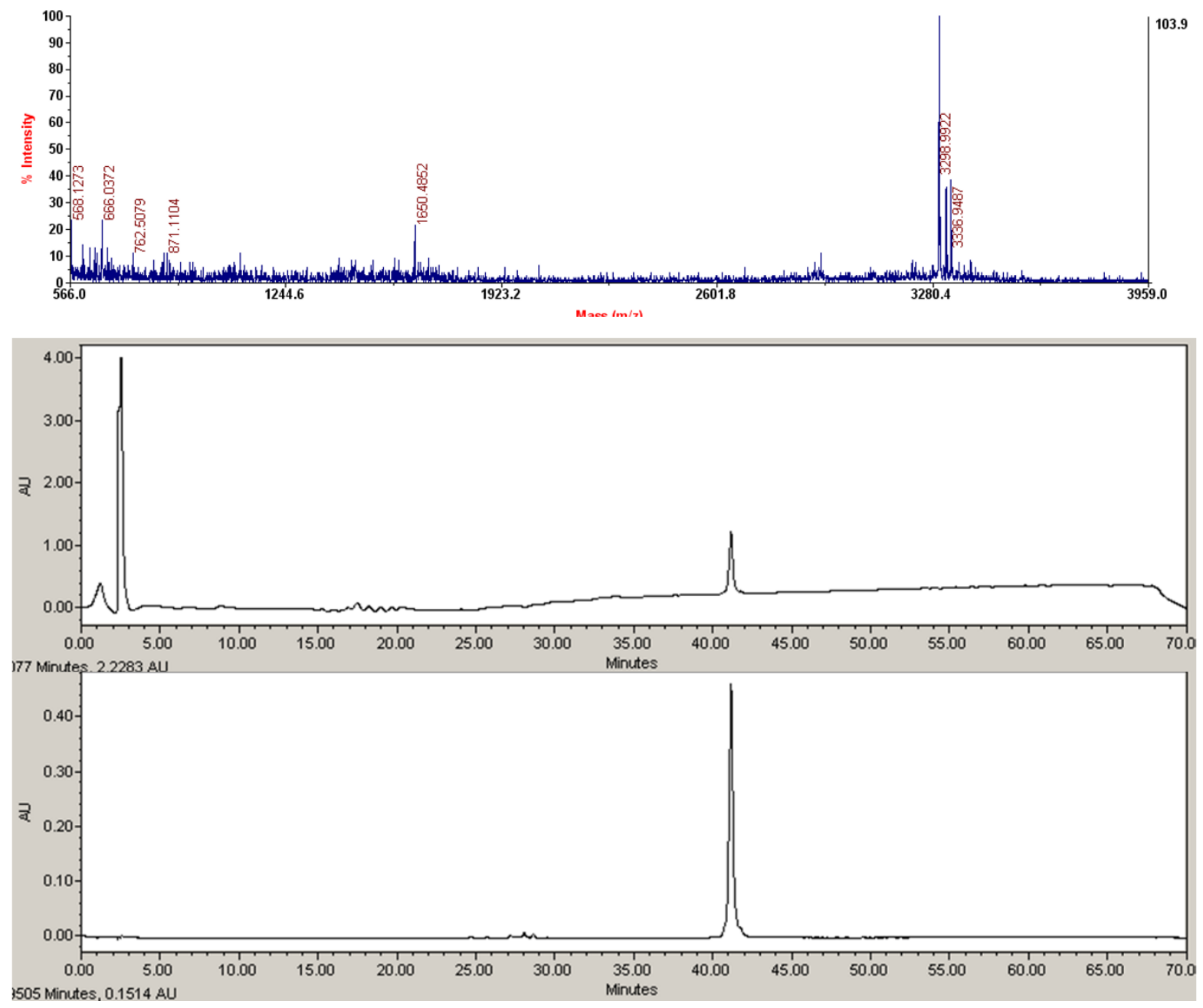

Figure S19: Characterization of compound 5. 


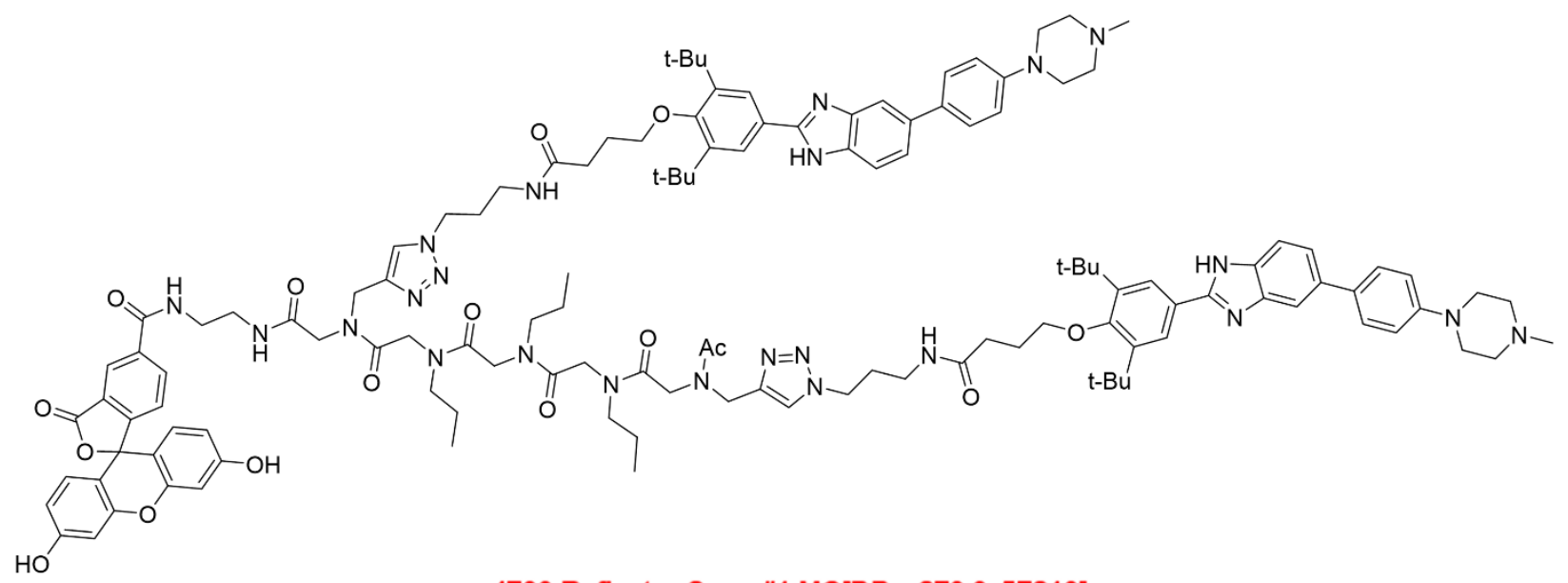

4700 Reflector Spec \#1 MC[BP = 379.0, 57310]
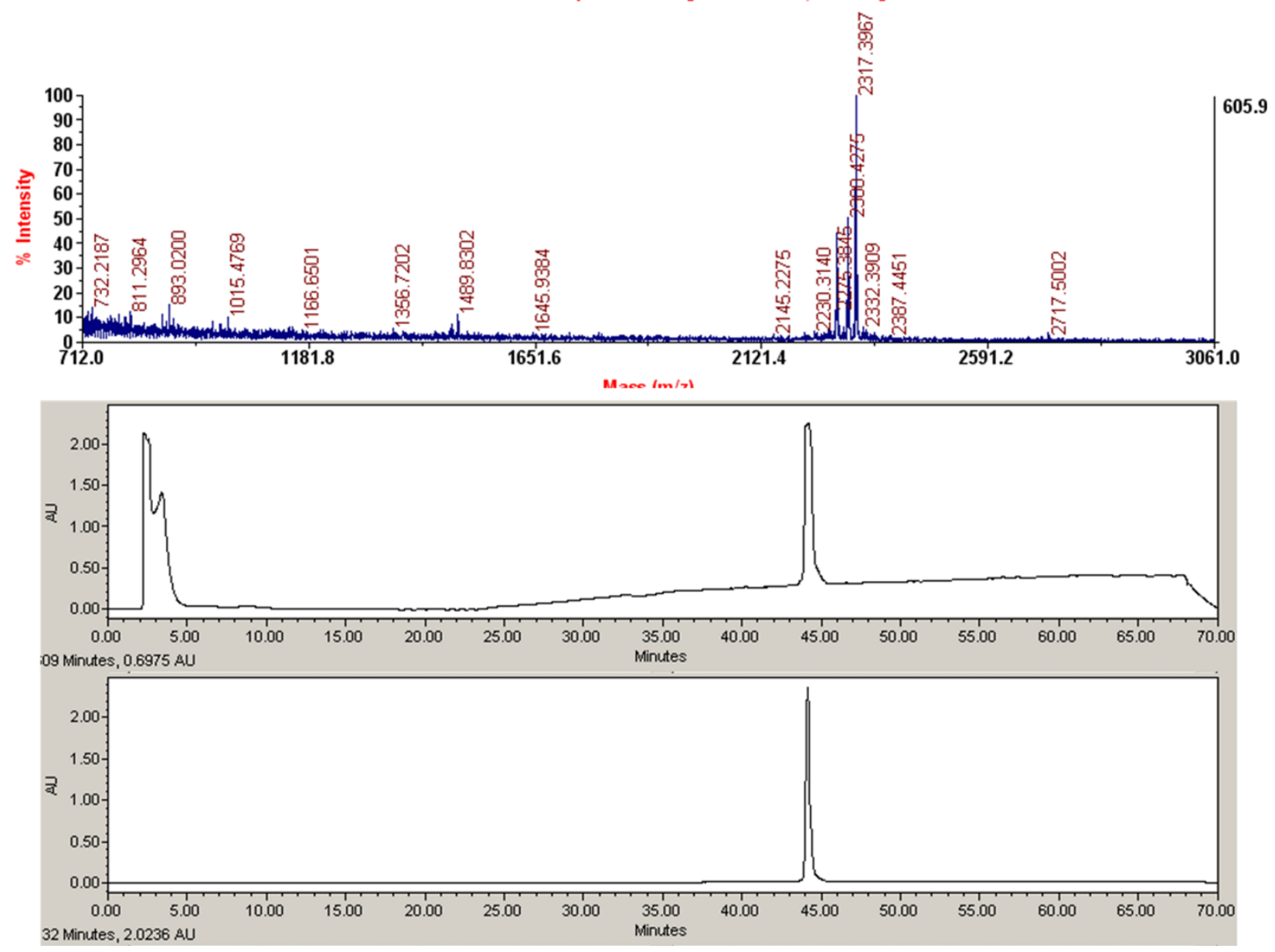

Figure S20: Characterization of 4-FL. 


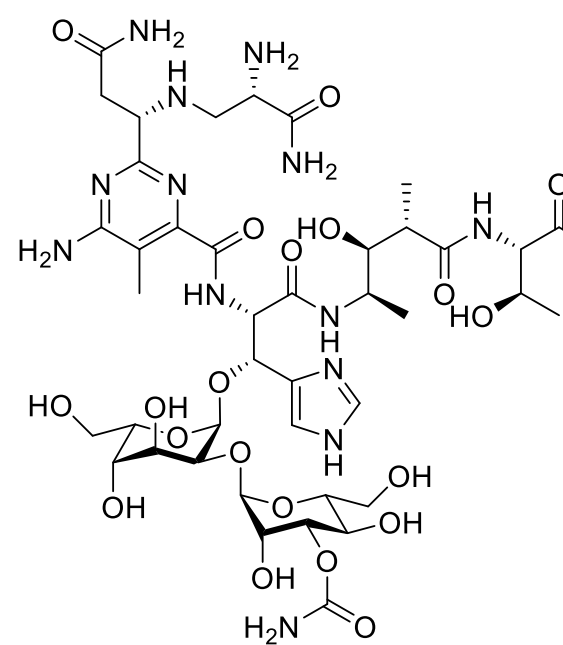<smiles>C#CCNCC(=O)N(CC#C)CC(=O)N(CCC)CC(=O)N(CCC)CC(=O)N(CCC)CC(=O)N(CC#C)CC(=O)NCCCNCCCNC(=O)c1csc(-c2csc(CCN)n2)n1</smiles>

Chemical Formula: $\mathrm{C}_{84} \mathrm{H}_{128} \mathrm{~N}_{24} \mathrm{O}_{27} \mathrm{~S}_{2}$

Exact Mass: 1968.8822

Molecular Weight: 1970.2090

4700 Reflector Spec \#1 MC[BP $=379.1,66741]$
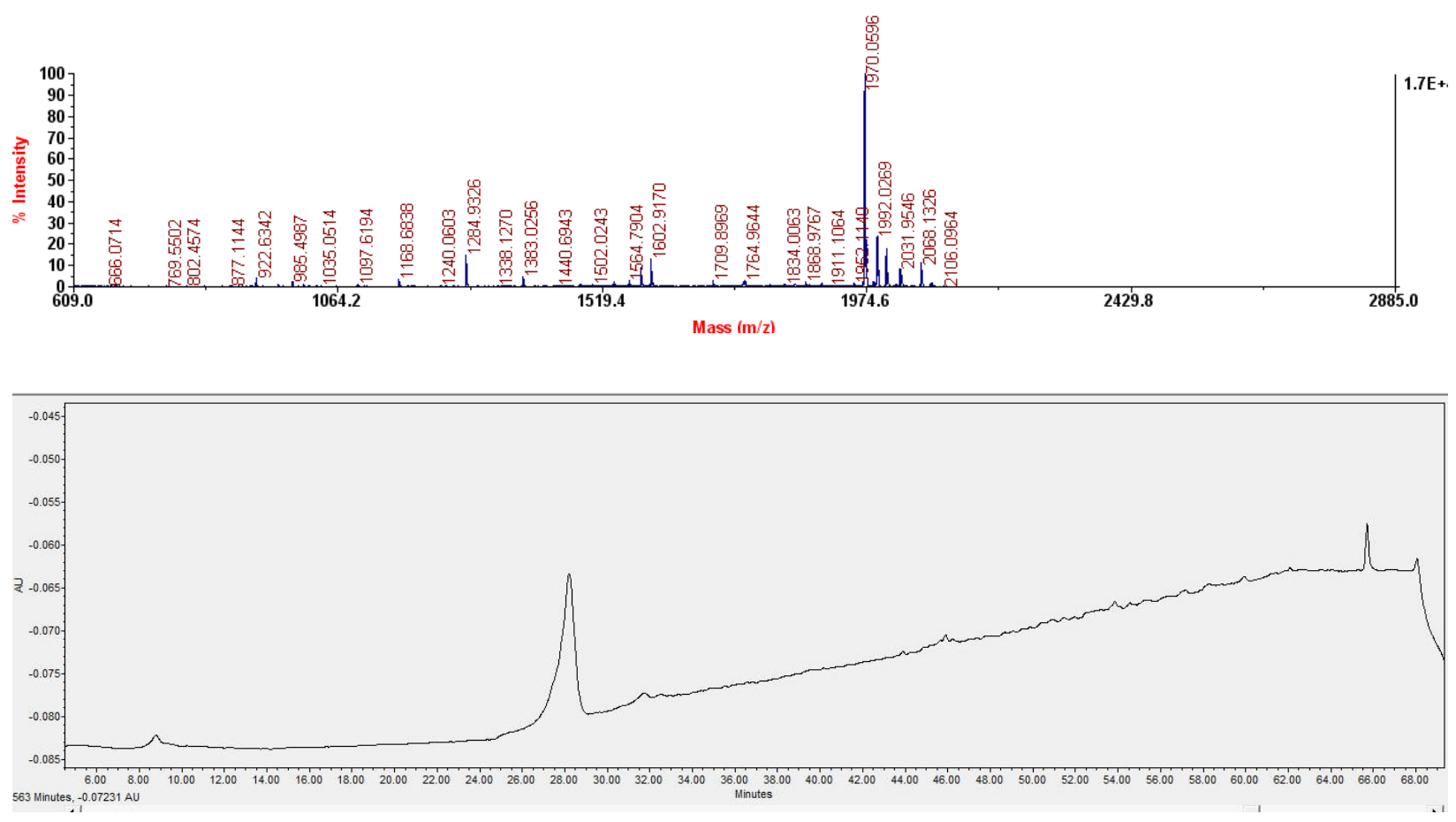

Figure S21: Characterization of 6. 

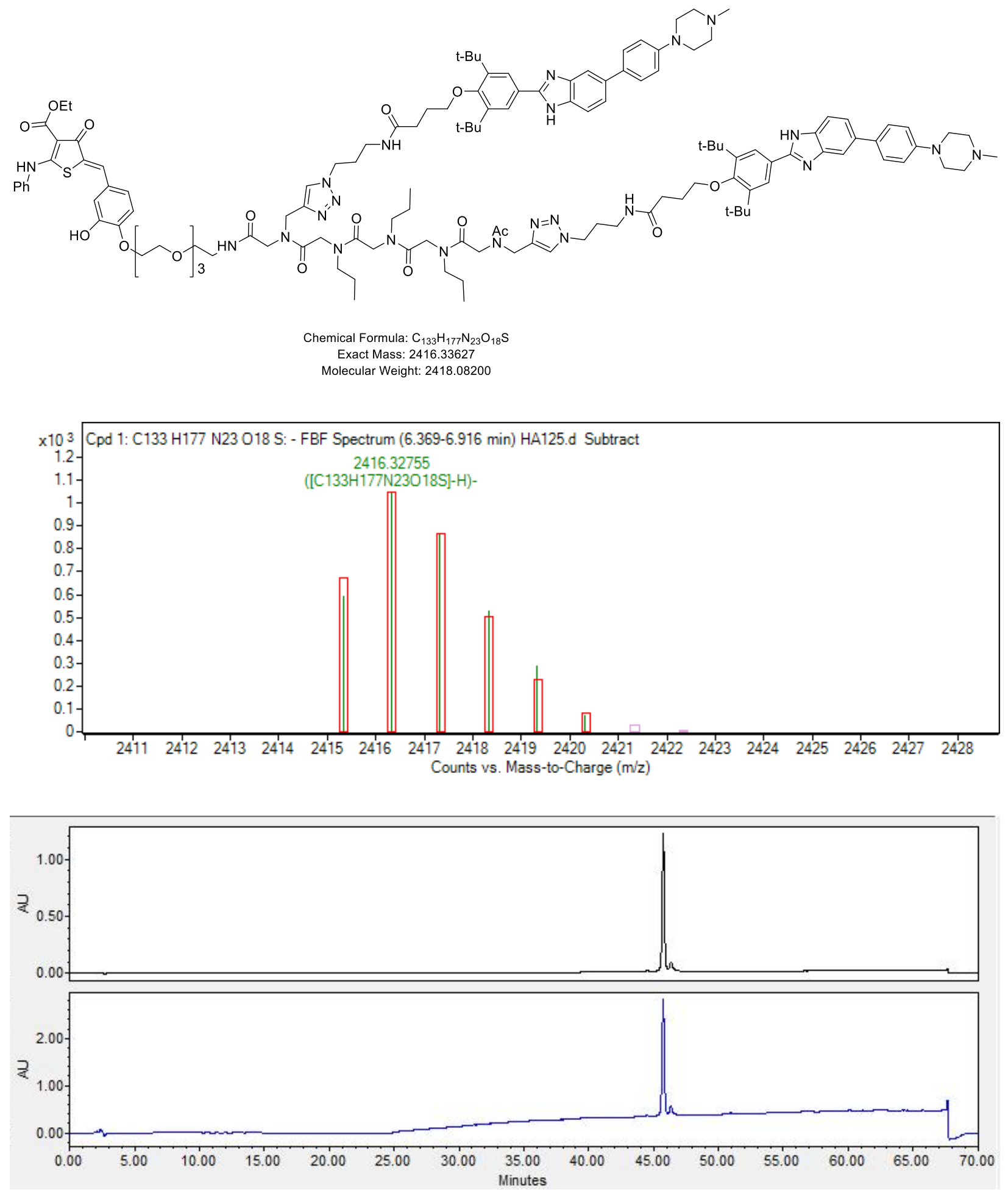

Figure S22: Characterization of 7 


\section{REFERENCES}

1. Angelbello, A. J.; Disney, M. D., Bleomycin can cleave an oncogenic noncoding RNA. Chembiochem 2018, 19 (1), 43-47.

2. Zou, W. P.; Wolchok, J. D.; Chen, L. P., PD-L1 (B7-H1) and PD-1 pathway blockade for cancer therapy: Mechanisms, response biomarkers, and combinations. Sci. Transl. Med. 2016, 8 (328), 328rv4-328rv4.

3. Boussiotis, V. A., Molecular and biochemical aspects of the PD-1 checkpoint pathway. N. Engl. J. Med. 2016, 375 (18), 1767-1778.

4. Zhang, J.; Bu, X.; Wang, H.; Zhu, Y.; Geng, Y.; Nihira, N. T.; Tan, Y.; Ci, Y.; Wu, F.; Dai, X.; Guo, J.; Huang, Y.-H.; Fan, C.; Ren, S.; Sun, Y.; Freeman, G. J.; Sicinski, P.; Wei, W., Cyclin D-CDK4 kinase destabilizes PD-L1 via cullin 3-SPOP to control cancer immune surveillance. Nature 2017, 553, 91.

5. Gotwals, P.; Cameron, S.; Cipolletta, D.; Cremasco, V.; Crystal, A.; Hewes, B.; Mueller, B.; Quaratino, S.; Sabatos-Peyton, C.; Petruzzelli, L.; Engelman, J. A.; Dranoff, G., Prospects for combining targeted and conventional cancer therapy with immunotherapy. Nat. Rev. Cancer 2017, 17, 286.

6. Rao, X.; Huang, X.; Zhou, Z.; Lin, X., An improvement of the $2^{\wedge}$ (-delta delta CT) method for quantitative real-time polymerase chain reaction data analysis. Biostat. Bioinforma. Biomath. 2013, 3 (3), 71-85.

7. Velagapudi, S. P.; Luo, Y.; Tran, T.; Haniff, H. S.; Nakai, Y.; Fallahi, M.; Martinez, G. J.; Childs-Disney, J. L.; Disney, M. D., Defining RNA-small molecule affinity landscapes enables design of a small molecule inhibitor of an oncogenic noncoding RNA. ACS Cent. Sci. 2017, 3 (3), 205-216.

8. $\quad$ Velagapudi, S. P.; Cameron, M. D.; Haga, C. L.; Rosenberg, L. H.; Lafitte, M.; Duckett, D. R.; Phinney, D. G.; Disney, M. D., Design of a small molecule against an oncogenic noncoding RNA. Proc. Natl. Acad. Sci. U. S. A. 2016, 113 (21), 5898-903.

9. Cox, J.; Mann, M., MaxQuant enables high peptide identification rates, individualized p.p.b.-range mass accuracies and proteome-wide protein quantification. Nat. Biotechnol. 2008, 26 (12), 1367-72.

10. Costales, M. G.; Aikawa, H.; Li, Y.; Childs-Disney, J. L.; Abegg, D.; Hoch, D. G.; Velagapudi, S. P.; Nakai, Y.; Khan, T.; Wang, K. W.; Yildirim, I.; Adibekian, A.; Wang, E. T.; Disney, M. D., Small-molecule targeted recruitment of a nuclease to cleave an oncogenic RNA in a mouse model of metastatic cancer. Proc. Natl. Acad. Sci. U.S.A. 2020, doi/10.1073/pnas.1914286117. 